\title{
Hanford Cultural Resources Laboratory Annual Report for Fiscal Year 1990
}
J. C. Chatters
H. A. Gard
P. E. Minthorn

November 1991

Prepared for the U.S. Department of Energy under Contract DE-AC06-76RLO 1830

Pacific Northwest Laboratory Operated for the U.S. Department of Energy by Battelle Memorial Institute 


\title{
DISCLAIMER
}

This report was prepared as an account of work sponsored by an agency of the United States Government. Neither the United St ates Covernment nor any agency thereof, nor Battelle Memorial Institute, nor any of their employees, makes any warranty, expressed or implied, or assumes any legal liability or responsibility for the accuracy, completeness, or usefulness of any information, apparatus, product, or process disclosed, or represents that its use would not infringe privately owned rights. Reference herein to any specific commercial product, process, or service by trade name, trademark, manufacturer, or otherwise does not necessarily constitute or imply its endorsement, recommendation, or favoring by the United States Government or any agency thereof, or Battelle Memorial Institute. The views and opinions of authors expressed herein do not necessarily state or reflect those of the United States Government or any agency thereof.

\author{
PACIFIC NORTHWEST LABORATORY \\ operated by \\ BATTELLE MEMORIAL INSTITUTE \\ for the \\ UNITED STATES DEPARTMENT OF ENERGY \\ under Contract DE-ACO6-76RLO 1830
}

Printed in the United States of America

Available to DOE and DOE contractors from the

Office of Scientific and Technical Information, P.O. Lox 62, Oak Ridge, TN 37831; prices available from (615) 576-8401. FTS 626-8401.

Available to the public from the National Technical Information Service, U.S. Department of Commerce, 5285 Por' Royal Rd., Sp:ingfield, VA 22161. 
PNL --7853

DE92 003622

HANFORD CULTURAL RESOURCES LABORATORY ANNUAL REPORT FOR FISCAL YEAR 1990

J. C. Chatters

H. A. Gard

P. E. Minthorn

November 1991

Prepared for

the U.S. Department of Energy

under Contract DE-AC06-76RLO 1830

Pacific Northwest Laboratory

Richland, Washington 99352 


\section{EXECUTIVE SUMMARY}

The Hanford Cultural Resources Laboratory (HCRL) was established by the U.S. Department of Energy Field Office, Richland (RL) in 1987 as part of Pacific Northwest Laboratory. The HCRL provides support for managing the archaeological, historical, and cultural resources of the Hanford Site, Washington; in a manner consistent with federal statutes and regulations. This report summarizes activities of the HCRL during fiscal year (FY) 1990.

The HCRL responsibilities have been set forth in the Hanford Cultural Resources Management Plan (HCRMP) as a prioritized list of tasks. The task list guided cultural resources management activities during FY 1990 and is the outline for this report. In order, these tasks were to 1) conduct cultural resource reviews, 2) develop an archaeological resources protection plan, 3) monitor the condition of known archaeological sites, 4) plan a curation system for artifacts and records, 5) evaluate cultural resources for potential nomination to the National Register of Historic Places, 6) educate the public about cultural resources, 7) conduct a sample archaeological survey of Hanford lands, and 8) gather ethnohistorical data from Native American elders.

Pursuant to Section 106 of the National Historic Preservation Act (NHPA), cultural resource reviews precede each proposed ground disturbing or building alteration/demolition project on the Hanford Site. During FY 1990, Hanford contractors requested 122 Section 106 reviews, 22 of which required archaeological surveys. The surveys covered 302 ha and revealed 18 prehistoric archaeological sites and 4 historic archaeological sites. Projects were relocated to avoid impact to two significant sites in the vicinity of the 300 Area.

A draft plan addressing federal agencies' responsibilities under the Archaeological Resources Protection Act (ARPA), protection issues at the Hanford Site, and measures for preventing violation of ARPA was submitted to the RL for review. Proposed prevention measures include educating Site workers and the general public, training law enforcement personnel, and establishing an archaeological site surveillance program.

The archaeological site monitoring program is designed to determine the baseline condition of cultural resources and to determine whether the RL's cultural resources management and protection policies are effective. Results of monitoring are used in planning for cultural resources management and protection. Staff monitored the condition of 39 sites, including 11 cemeteries, 20 sites listed on the National Register of Historic Places (National Register), and 8 sites that have not been so listed. Four conclusions were drawn: 1) Natural erosion is the most destructive force at the inspected sites. 2) Sites inside the Hanford security fence show little sign of disturbance. 3) Areas open to public use 
show more anthropogenic impacts, although these are not severe. 4) A determined looter is difficult to deter with only a fence. Based on these observations, the HCRL recommends increased education and surveillance efforts, as outlined in the protection plan, and revegetation of some areas subject to severe erosion.

Following guidelines for ARPA compliance, a system was proposed for curation of artifacts and associated records obtained from the Hanford Site during the past 22 years. The first step in the planning process, establishing the location of collections, was accomplished in FY 1989. During FY 1990, collections were inspected and their volumes and contents established. A preliminary design was prepared for a curation facility that would meet federal guidelines.

Evaluations for potential nomination to the National Register of Historic Places were conducted for two properties during FY 1990, and documentation was completed for nomination of a third. Mapping, surface collection, and subsurface testing were conducted at archaeological sites 45BN50 and 45BN412, both of which were found to meet National Register criteria. Site 45BN50 is a campsite occupied for the past 3000 years and was one of the places where tenets of the Washane religion were developed. Site 45BN412 is a bison kill and butchering site used approximately 1500 to 2000 years ago. The nomination of the 100-B Reactor to the National Register was revised, has been concurred with by the Washington State Historic Preservation Officer and his advisory commission, and is being considered by the U.S. Department of Energy Headquarters for submission to the Keeper of the National Register.

The education program, which was planned in FY 1989, consists of three parts, targeting elementary and middle school students, secondary school students, and the general public. As part of implementing this plan, Pacific Northwest Laboratory's Public Relations staff prepared a brochure on cultural resources management at Hanford, and lectures were presented to six adult organizations.

The archaeological survey of areas of the Hanford Site not targeted for development is a requirement of Section 110 of the NHPA and of 1988 amendments to ARPA. The HCRMP specifies that a $10 \%$ stratified random sample of Hanford Site lands will be surveyed during a 5 -year period. Because of the high level of effort required for other tasks in FY 1990, only $2.08 \mathrm{~km}^{2}$ was surveyed. Survey plots were located in a variety of terrain. Sites were found in greater number and variety in areas of high relief, such as slopes, buttes, and escarpments.

The lowest-priority task is collection of ethnographic and ethnohistorical information about traditional cultural uses and meaning of the Hanford Site. Information relating to oral histories, traditional beliefs, and past lifeways was elicited from four elders of the Nez Perce, Umatilla, and Palouse tribes. 


\section{CONTENTS}

EXECUTIVE SUMMARY ...................................................... iii

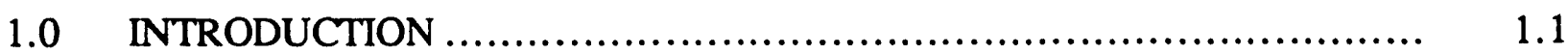

$2.0 \quad$ SECTION 106 COMPLIANCE REVIEWS ............................... 2.1

2.1 REVIEWS CONDUCTED ........................................... 2.1

2.2 CULTURAL RESOURCES LOCATED ................................. 2.2

3.0 HANFORD SITE ARCHAEOLOGICAL RESOURCES PROTECTION

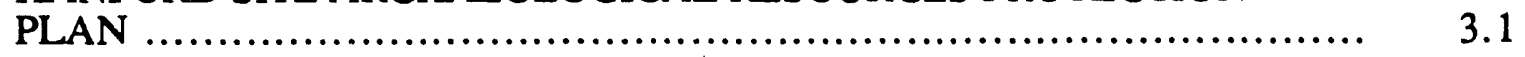

4.0 THE MONITORING PROGRAM..................................... 4.1

4.1 CEMETERY SITES ................................................... 4.1

4.2 SITES LISTED ON THE NATIONAL REGISTER .................... 4.4

4.3 SITES NOT LISTED ON THE NATIONAL REGISTER ............... 4.5

4.4 CONCLUSIONS AND RECOMMENDATIONS............................. 4.6

5.0 THE CURATION PROGRAM................................................ 5.1

6.0 EVALUATION OF KNOWN CULTURAL RESOURCE SITES

FOR ELIGIBILITY TO THE NATIONAL REGISTER

OF HISTORIC PLACES ..................................................... 6.1

6.1 NOMINATION OF THE 100-B REACTOR ............................ 6.1

6.2 ARCHAEOLOGICAL SITE 45BN90 ................................. 6.1

6.3 ARCHAEOLOGICAL SITE 45BN412 .............................. 6.3

7.0 THE PUBLIC EDUCATION PROGRAM................................... 7.1

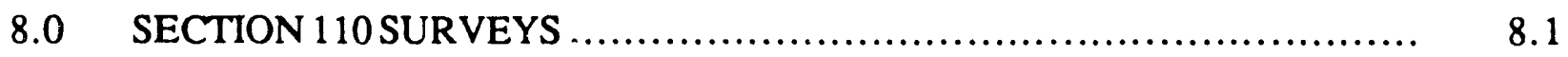

$9.0 \quad$ ETHNOHISTORY ....................................................... 9.1

9.1 TRADITIONAL CULTURAL PROPERTIES ......................................... 9.1

9.2 INTERVIEWS WITH KNOWLEDGEABLE TRIBAL

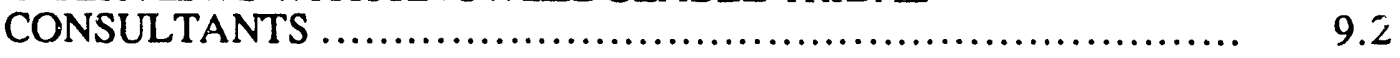




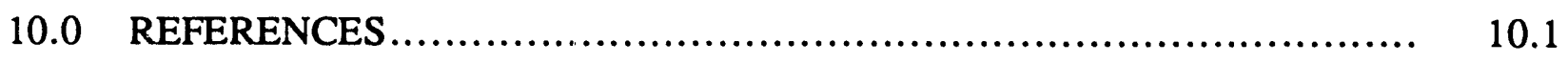

APPENDIX A - SECTION 106 REVIEWS CONDUCTED AT THE

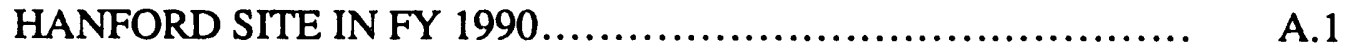

APPENDIX B - CULTURAL RESOURCES MONITORING OBSERVATIONS

FOR THE FY 1990 MONITORING CYCLE ....................... B. 1

APPENDIX C - RANDOMLY SELECTED SURVEY PLOTS INVESTIGATED

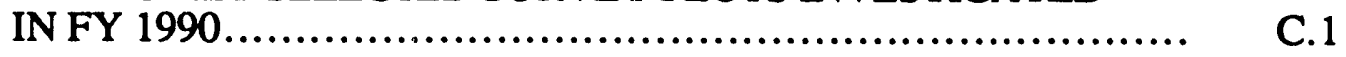




\subsection{INTRODUCTION}

The Hanford Cultural Resources Laboratory (HCRL) was established by the U.S. Department of Energy Field Office, Richland (RL) in 1987 as part of Pacific Northwest Laboratory (PNL). (a) The HCRL provides support for managing the archaeological, historical, and cultural resources of the Hanford Site, Washington, in a manner consistent with the National Historic Preservation Act of 1966, the Archaeological Resources Protection Act of 1979, and the American Indian Religious Freedom Act of 1978.

In fiscal year (FY) 1989, the HCRL published the Hanford Cultural Resources Management Plan that, among other things, established a prioritized list of tasks to be undertaken to bring the RL into compliance with federal statutes, regulations, and guidelines. That list of tasks (Table 1.1) was used to guide cultural resources management activities during FY 1990.

This report is structured according to the priorities listing in Table 1.1. Each task is discussed in a separate section, except for Tasks 3 and 4, which are combined because they are identical in tactical terms. Each section includes an explanation of the task and a description of the tactics used in performing it, as appropriate. Results of the task or the products of task performance are then described or presented in their entirety. Supporting data and descriptive detail for Tasks 1, 3/4, and 8 are presented in Appendixes A through C.

(a) PNL is operated for the U.S. Department of Energy by Battelle Memorial Institute. 
TABLE 1.1. Priority Listing of Tasks Performed by the HCRL, FY 1989

Priority

\section{Task Description}

Conduct National Historic Preservation Act Section 106 compliance reviews.

Prepare a plan for protection of archaeological resources.

Verify, evaluate, and document the condition of extant cultural resources as a baseline for management.

Monitor the condition of historic properties on a 3-year rotating schedule.

Curate and report on collections from authorized archaeological investigations on the Hanford Site (initiate in FY 1990).

Evaluate known cultural resources for eligibility to the National Register of Historic Places (three properties identified; see Section 6).

Educate the public and Hanford Site workers about cultural resource protection and preservation.

Evaluate the current model of archaeological resource distributions by a sample inventory of $10 \%$ of site lands (initiate in FY 1990).

Collect information on regional ethnohistory. 


\subsection{SECTION 106 COMPLIANCE REVIEWS}

As required by Section 106 of the National Historic Preservation Act, the U.S. Department of Energy (DOE) reviews each proposed ground disturbing or building alteration/demolition project to determine whether it may have an impact on any cultural property that is listed on or eligible for the National Register of Historic Places. This study is accomplished through the cultural resource review process (Chatters 1989, Section 3.1.1). For efficiency, cultural resource reviews are classified according to four criteria: 1) whether the project entails maintenance, demolition, or new construction; 2) the existence of previous disturbance in the area to be reviewed; 3) the cultural resource sensitivity of the area in which the activity is planned; and 4) whether the project involves an existing structure or building. Six classes result from these criteria: I) maintenance in a disturbed, low-sensitivity area; II) maintenance in a disturbed, high-sensitivity area; III) new construction in a disturbed, low-sensitivity area; IV) new construction in a disturbed, high-sensitivity area; V) all projects involving undisturbed ground; and VI) projects involving demolition or remodeling of existing structures. Each class requires a different response, as specified in Section 3 of the Hanford Cultural Resources Management Plan (Chatters 1989).

\subsection{REVIEWS CONDUCTED}

During FY 1990, Hanford contractors requested 122 cultural resource reviews. Most cases initiated in FY 1990 were Class III reviews (58), followed by Class V (34), Class VI (13), Class I and II (10), and Class IV (7). The majority of reviews were requested for the 300 and 600 Areas ( 30 and 29, respectively), followed by those for the 200 and 100 Areas (24 and 21). The remainder were fairly equally divided among the 400, 700, 1100, and 3000 Areas, and DOEadministered lands outside of the Hanford Site boundaries (see Table A.1 in Appendix A).

A new policy was implemented in FY 1990 regarding clearances for the fenced portions of the 200 Areas. Because these areas previously had been intensively surveyed for cultural properties (Chatters and Cadoret 1990), no new case numbers were assigned to projects occurring within those boundaries. Telephone clearance with subsequent permit signatures was provided, along with reference to PNL-7264 (Chatters and Cadoret 1990). A total of 112 clearances of this type were provided for the 200 Areas. An additional 25 telephone/signature clearances were provided for other areas when the project entailed excavations of less than $5 \mathrm{ft}^{3}$, when emergencies necessitated immediate action, or when small-scale activities occurred in areas known to be disturbed and lacking cultural resources. 
In FY 1990, 26 cases requiring survey and 11 requiring monitoring were initiated. Six additional cases remaining from previous years were completed. Only two cases ini:-ated in FY 1990, 89-300-032 and 89-300-024, are still pending at this time. There is some overlap in the numbers of monitoring and survey cases because monitoring was required in some cases after the survey had been completed.

Thirty surveys were completed totaling $302.00 \mathrm{ha}$, or more than three times the area surveyed in FY 1989. The largest project (89-200-023) covered 69.13 ha. Three cases had areas greater than 50 ha, and five other cases covered more than 10 ha. The smailest case covered only 0.0007 ha. Most surveys covered less than 2 ha, and 13 ivere less than 1 ha. The vast majority of surveys occurred in the 600 Area (16), followed by the 300 Area (6), 200 Areas (3), 1100 Area (2), 400 Area (1), 100 Areas (1), and one outside of normally recognized boundaries (see Appen$\operatorname{dix} A$ ). Not all Class $V$ cases required survey, with three projects initiated in areas previously surveyed and others requiring only monitoring because of the nature and scale of the impact.

\subsection{CULTURAL RESOURCES LOCATED}

During the course of the Section 106 clearance process, 22 archaeological sites were recorded (see Appendix A). Eighteen of these are prehistoric, the remainder historic. Projects in which cultural resources were located are 88-600-011, 89-200-023, 89-300-023, 89-600-010, 89-600-011, 89-1100-003, 90-600-006, and 90-600-012 (see Appendix A). Fourteen prehistoric sites, consisting of lithic scatters and cairns, were recorded on Saddle Mountain during case 88-600-011. Four prehistoric sites were recorded during the review for the 200 Areas Treated Effluent Disposal Facilities (89-200-023). The four historic sites are located in the 300 Area (89-300-023), the 600 Area (89-600-010), and the 1100 Area (89-1100-003). One additional prehistoric site was located but not formally recorded (89-600-011). Three isolated artifacts--a cobble tool, an evaporated milk can dating from 1915, and an Oregon license plate dating from 1925--were also recorded.

Two previously recorded archaeological sites, deemed eligible for nomination to the National Register of Historic Places, were discovered to be within the area of potential effect for two projects (89-300-026 and 89-300-019). Major ground disturbing activity was directed away from these sites, and monitoring of all excavations was required.

Of the surveys conducted and sites recorded during FY 1990, the Saddle Mountain area proved to be the most interesting, containing a large number of varied yet apparently interrelated sites. A.lthough the survey area was restricted to a narrow corridor, no less than 14 sites were 
recorded. Stone cairns associated with religious vision quests and stone tool processing stations composed the bulk. of these sites. However, hunting blinds and possible storage pits, found along the talus slopes by researchers on their way to the survey area, were noted in abundance. Apparently, the entire mosaic of hunting behaviors is represented in this region, from weapon preparation to kill sites, from food storage to the cosmologies necessary to provide a hunter with a spirit guardian. Taken individually, the Saddle Mountain sites may seem unimpressive; yet when viewed as representative of an entire range of activities, these isolated features serve to clarify our understanding of past lifeways. Additionally, this cursory survey has further supported the reports that this area was one of the three vision quest localities utilized by practitioners of the Dreamer Religion within the Hanford vicinity. 


\subsection{HANFORD SITE ARCHAEOLOGICAL RESOURCES PROTECTION PLAN}

The Hanford Site contains more than 150 known archaeological sites ranging in age from more than 7000 years to less than 100 years. These sites contain artifacts that are of interest to private collectors and are, therefore, subject to diminishment by looting and vandalism. Federal statutes require the DOE to protect these fragile, nonrenewable manifestations of our nation's heritage and provide means for enforcing prohibitions against unauthorized collecting and damage to these resources. During FY 1990, a draft plan was developed that outlines the iegal basis for archaeological resources protection; describes archaeological resources protection issues faced at the Hanford Site; and offers measures to be used by the RL and its agent, the HCRL, to enhance archaeological resources protection.

The federal statutes that drive archaeological protection activities on the Hanford Site are the National Historic Preservation Act (NHPA) and the Archaeological Resources Protection Act (ARPA). Section 110 of the furmer stipulates that federal agency heads have the responsibility to maintain the historic properties under their jurisdiction; in the case of the Hanford Site, these properties consist primarily of archaeological sites and objects. The ARPA specifically prohibits the damage, destruction, collection, trade, sale, or transportation of items of archaeological interest from federal land without a permit from the land-managing agency. When these two statutes are considered together, they assign the RL the responsibility to prevent violations of ARPA, enforce ARPA, and maintain confidentiality of information about archaeological resources on the Hanford Site. The National Park Service has promulgated uniform rules and regulations for the implementation of ARPA under 43 CFR 7, which the plan was developed to address.

Two archaeological resources protection issues were identified, based on stipulations of ARPA: 1) direct impacts to archaeological resources and 2) confidentiality of archaeological resource information. The archaeological site monitoring task, described in Section 4, identifies arcas receiving impact from relic collectors in violation of ARPA. Based on 1989 monitoring and general knowledge of archaeological resource distributions on the Hanford Site (Rice 1980; Chatters 1989), the Site was divided into three zones, each with unique archaeological protection needs and an identifiable population of potential violators.

The issue of confidentiality of archaeological site records is internal to the HCRL and cultural resource staff of the RL. To meet statutory obligations, inadvertent release of precise site location information must be avoided, keeping archaeological site records out of the eye of the public and Hanfora Site workers without a need to know. The protection plan report identifies areas of needed improvement in the area of record protection. 
The draft plan proposes protection measures to address the issues listed above. Because they are still under discussion, details of prevention and enforcement measures are not presented here. In general, they include information campaigns directed at Hanford Site workers and various segments of the general public, tighter control of archaeological site records, training of enforcement personnel, increased surveillance of vulnerable archaeological resources, and active prosecution of violators.

The protection plan will be finalized in FY 1991, following discussions among the staff of the Site Management Division, the Safeguards and Security Department, and the HCRL. 


\subsection{THE MONITORING PROGRAM}

As manager of the Hanford Site, the DOE is assigned the stewardship of all archaeological resources, traditional use areas, paleontological deposits, and historic properties onsite. The RL therefore is responsible for determining whether its management and protection policies are effective and when they are inadequate. To determine the impact of DOE policies and to safeguard cultural resources from destruction by natural processes or unauthorized excavation and collection, the HCRL will maintain a monitoring program. The monitoring program is designed to inspect each cemetery site once a year, each site listed on the National Register of Historic Places (National Register) at least every 3 years, and each nonlisted site every 5 years. Sites that are found by monitoring to be receiving impacts, particularly from DOE actions and unauthorized collection activity, will be reinspected annually, at a minimum. Results of monitoring are used in planning for cultural resource site management and protection.

To select the sample of sites to be inspected in FY 1990, Laboratory staff first identified the cemeteries known to exist onsite, then stratified the remaining National Register sites according to site type as listed on the State of Washington Archaeological Site Record. Sites were listed as house-pit sites, open camps, and fishing stations, following definitions used by Rice (1968a, b) for these categories. Site age was not included as a category because so few of the site records contain this kind of information. A random 33\% sample of National Register sites was chosen. An additional group of sites not yet listed on the National Register, but situated within the area expected to be frequented by boaters using the planned Vernita boat launch, was added to the list. Including the cemeteries, this made a list of 40 sites (Figure 4.1). Monitoring results are described below on a site-by-site basis, and findings are summarized in Table 4.1.

\subsection{CEMETERY SITES}

The purpose of inspecting cemetery sites is to evaluate their condition and document any erosion, vandalism, looting, or unintentional disturbance as a background for developing and maintaining effective measures for protecting these sites. Their inspection is not intended as a means to collect data to verify the sites' existence, their identification as cemeteries, or their listing on the National Register of Historic Places. 


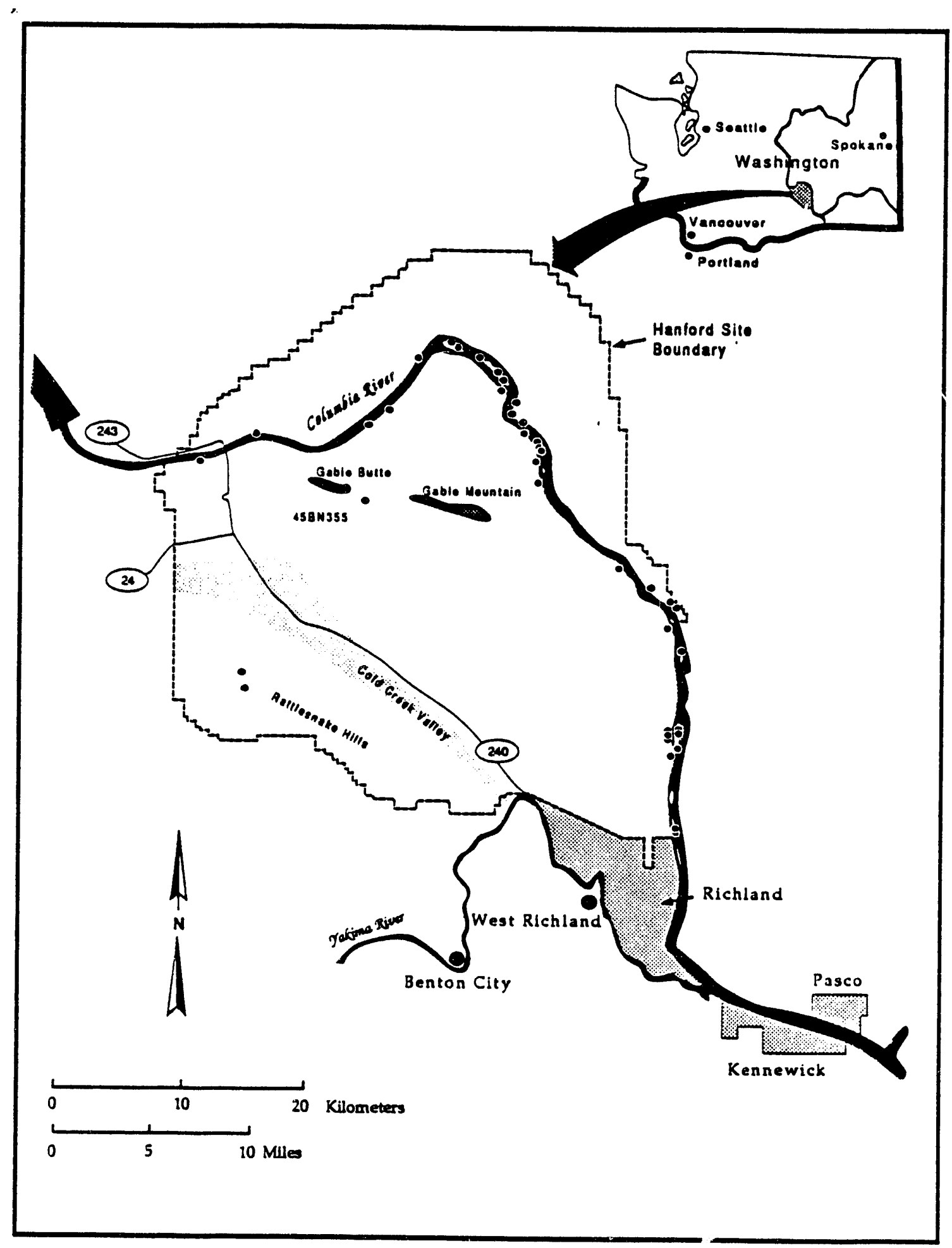

FIGURE 4.1. Locations of Archaeological Sites Monitored in FY 1990 
TABLE 4.1. Observations and Recommendations from FY 1990 Archaeological Site Monitoring

\begin{tabular}{|c|c|c|c|}
\hline Site No. & Monitoring Group & Disturbar.ce Type $^{(a)}$ & Conclusion/Recommendation ${ }^{(b)}$ \\
\hline 45BN36 & Register & WE, WA & Combine with BN111 and BN112 \\
\hline 45BN38 & Non-Register & None & Does not exist, remove from records \\
\hline $45 \mathrm{BN} 41$ & Register & WA & (b) \\
\hline $45 \mathrm{BN} 42$ & Non-Register & WE, WA & (b) \\
\hline $45 \mathrm{BN} 108$ & Register & WE, WA & (b) \\
\hline $45 \mathrm{BN} 110$ & Register & PR, WA & (b) \\
\hline $45 \mathrm{BN} 111$ & Register & WE, WA & Combine with BN112 and BN36 \\
\hline $45 \mathrm{BN} 112$ & Register & WE, WA & Combine with BN111 and BN36 \\
\hline 45BN113 & Non-Register & WA & (b) \\
\hline $45 \mathrm{BN} 116$ & Register & VT & Further evaluation \\
\hline $45 \mathrm{BN} 124$ & Cemetery & VT & (b) \\
\hline $45 B N 128$ & Cemetery & $\mathrm{TR}, \mathrm{WE}$ & (b) \\
\hline $45 \mathrm{BN} 129$ & Cemetery & WE, WA & Further evaluation \\
\hline 45BN130 & Register & WE, WA & (b) \\
\hline $45 \mathrm{BN} 131$ & Register & $\mathrm{CD}, \mathrm{WA}$ & Increase surveillance \\
\hline $45 \mathrm{BN} 140 / 139$ & Cemetery & WE, WA & Combine into one site \\
\hline 45BN142 & Cemetery & None & (b) \\
\hline $45 \mathrm{BN} 143$ & Cemetery & WE, WA, SC & Increase surveillance \\
\hline $45 \mathrm{BN} 151$ & Cemetery & VT & Replace sign \\
\hline $45 \mathrm{BN} 157 \mathrm{~b}$ & Cemetery & $\mathrm{VD}, \mathrm{CD}, \mathrm{WE}, \mathrm{WA}$ & Increase surveillance \\
\hline 45BN164 & Non-Register & WE, WA & (b) \\
\hline $45 B N 168$ & Non-Register & WE & Evaluate for nomination \\
\hline 45BN17' & Register & Unknown & Unabie to locate \\
\hline $45 \mathrm{BN} 173$ & Register & Unknown & Unable to locate \\
\hline $45 \mathrm{BN} 176$ & Register & & Site buried, leave on register \\
\hline $45 \mathrm{BN} 179$ & Register & $\mathrm{D}, \mathrm{TP}, \mathrm{WA}$ & Backfill pits \\
\hline $45 \mathrm{BN} 354$ & Register & VD & Further evaluation \\
\hline 45BN355 & Register & VD & Further evaluation \\
\hline $45 \mathrm{FR} 257$ & Register & WA & (b) \\
\hline 45FR258 & Register & $\mathrm{TR}, \mathrm{CD}$ & Increased surveillance \\
\hline 45FR259 & Register & WA & Further evaluation \\
\hline 45FR264 & Non-Register & WE, WA, SC & Evaluate for nomination \\
\hline 45FR266 & Non-Register & TR, VD, TP & Stabilization \\
\hline 45GR301 & Non-Register & WE, WA & Further evaluation \\
\hline $45 G R 302 b$ & Register & WE, WA & \\
\hline $45 \mathrm{GR} 302 \mathrm{c}$ & Cemetery & None & Further evaluation \\
\hline $45 \mathrm{GR} 305$ & Register & $\mathrm{WE}$ & \\
\hline 45GR306c & Cemetery & PR, SC & İncrease surveillance \\
\hline $45 \mathrm{GR} 317$ & Cemetery & SC & Evaluate, increase surveillance \\
\hline
\end{tabular}
(a) Disturbance type abbreviations: WE, wind erosion; WA, water erosion; PR, public recreation; VT, vehicle traffic; TR, trespassing; $C D$, collector digging; $S C$, surface collecting; $\mathrm{VD}$, vandalism; C, construction; $\mathrm{D}$, noncollector digging; TP, open test pits.
(b) No recommendation. 
Eight cemeteries were originally identified on the Hanford Site by Wanapum Indian leaders, from archaeological evidence of burials, or both. Additional fieldwork and literature searches have brought this number to 13 . All of these cemetery sites were monitored in FY 1990 with the exception of 45BN125, the status of which is still in doubt (Chatters et al. 1990). Two additional sites, 45GR317 and 45GR302c, were incleded on the list of cemeteries based on the original field records that described the presence of burials.

Damage to cemeteries varies, but in general sites in this category are undisturbed by modern human activity. Wind erosion is the most severe type of damage observed. Sites 45BN142, 45BN124, and 45BN151 are in stabilized dunes and exhibit no erosion. Erosion is severe enough to expose human remains at 45BN128,45BN140, and 45BN143. Looting is still evident at 45BN157b, around which a cyclone security fence was erected in the fall of 1989 to curtail trespassing. When HCRL staff members arrived to inspect the site in the summer of 1990 , it was discovered that the gate had been rammed by a vehicle, creating a gap in the fence large enough for a person to pass through. At least one area within the site had been subjected to unauthorized excavation.

\subsection{SITES LISTED ON THE NATIONAL REGISTER}

Twenty of the monitored sites, excluding the cemeteries, are listed on the National Register of Historic Places. These sites are included in the Savage Island (45BN116, 45FR257, 45FR258, 45FR259), Hanford North (45BN130, 45BN131), Locke Island (45BN176, 45GR302b, 45GR305), Wooded Island (45BN108, 45BN110, 45BN111, 45BN112, 45BN36, 45BN41), Snively Canyon (45BN172, 45BN173), and Ryegrass (45BN149 [and enclosed 45BN179, 45BN180]) Archaeological Districts. Sites 45BN354 and 45BN355 are located in the Gable Butte/Gable Mountain Archaeological District, which is pending nomination. Concerns are slightly different in the case of National Register listings. Evidence of damage, looting, or erosion were again of primary importance, but whether the site could be found and actually appeared to contain data of scientific significance was also important. In some cases, absence of the site as described or the lack of evidence for scientific significance may warrant removal of a site from the National Register.

Observations made by HCRL staff are presented in Appendix A. Three sites (45BN36, $45 B N 111$, and 45BN112) were determined to actually represent one continuous site and should be placed under one designator (45BN36). 45BN176 was found to be buried beneath $3 \mathrm{~m}$ of fill material. Because this ethnographically known camp is probably still intact and is currently well protected, its status should remain unchanged. On two other sites (45FR259 and 45GR317), 
previously unrecorded features were discovered that increase the research and information potential of these sites. 45FR259 exhibits three parallel rows of large anthropogenically placed boulders that extend along the shoreiine for more than $800 \mathrm{~m}$. 45GR317 also $\epsilon$ xhibits shoreline features, but in the form of 17 regularly spaced depressions. The function of these features is open to speculation. The existence of similar features elsewhere is not reported in the professional literature. Further research into features such as these can potentially better illuminate prehistoric riverine adaptations, a fact that increases the significance of these sites.

Most of the sites inside the security fence in Benton County exhibited no signs of damage, except for minor wind erosion and, perhaps, surface collection by Site workers (Table 4.1). Sites 45FR258 and 45BN179 were revisited in FY 1990 to determine whether negative impacts noted during 1989 monitoririg (Chatters et al. 1990) were still occurring. Looting continues to be a problem at 45FR258 with signs of fresh digging. However, the fire break cut over 45BN179 was not regraded in FY 1990 and has become revegetated. The open test pit in this site continues to promote slumping and should be backfilled.

Damage to National Register sites again tends to be more severe on the Franklin and Grant County sides of the Columbia River and on the sides of the islands not visible from the secure portion of the Hanford Site. Many of the island sites exhibit signs of past digging, and the general absence of projectile points on the surface suggests extensive surface collecting. In general, however, with the exceptions of 45FR258 and 45BN157b, evidence of recent looting was quite rare. A previously unreported potential impact is the excavation of waterfowl hunting blinds on many of the islands. For example, several large pits were noted on Wooded Island. If this practice is allowed to continue, the potential to accidently damage a site is increased. The discovery of artifacts in the course of blind-digging may encourage further exploration.

\subsection{SITES NOT LISTED ON THE NATIONAL REGISTER}

Eight sites that have not been nominated to the National Register were also reviewed in FY 1990 (Table 4.1). These sites were inspected to determine whether they did in fact exist; to determine what damage, if any, they had received; and to consider their National Register potential. Sites found to have potential will be evaluated in more detail in the near future. Appendix A presents the results of monitoring at each site.

Based on monitoring observations, one site (45BN38) should be removed from state records because it could not be located. Three sites (45BN168, 45FR264, and 45GR301) should undergo further evaluation to determine whether they should be nominated to the National 
Register. 45FR266, the White Bluffs Cainin, is architecturally unique for the area and is the only standing structure on the Hanford Site that represents the early period of Euroamerican settlement. The structure should be stabilized and nomination procedures implemented. The remainder of the sites were not deemed significant.

Damage to this group of sites is similar in kind and gengraphic distribution to the National Register group. Sites inside the Hanford security fence showed signs of surface collection, in that artifacts such as net sinkers, which had been reported by the original discovery team, could not be found. No other damage was evident inside the fence, but sites outside the fence consistently showed some signs of relic collector activity.

\subsection{CONCLUSIONS AND RECOMMENDATIONS}

Based on the results of the FY 1990 monitoring program, several conclusions can be drawn. The situation at 45BN157b has demonstrated that deterring a determined looter is difficult, if not impossible. In spite of a well-built security fence, access was gained and damage was caused. The only effective solutions seem to be 1 ) increased public education programs to reach those who do not know any better, 2) increased patrolling of consistently impacted properties to catch those who do know better, and 3) blockage of the access roads to deter the casual vandals. The sites consistently impacted appear to be those with a long history of exploitation. Sites without evidence of past looting rarely show signs of recent looting and seem relatively immune. Those areas open to public recreation and with ease of access show the greatest negative anthropogenic impacts. This problem can be alleviated by increased surveillance during peak periods of public use (e.g., fishing and hunting seasons). Although noted in FY 1989 as a problem, no sign of damage from stock grazing was found on any cultural property in FY 1990. Natural erosion is currently the most destructive force impacting Hanford's archaeological sites. Although erosion is generally difficult to reverse, those sites with good vegetation development tended to be well stabilized. Vegetation also obscures the ground surface and thereby discourages casual collecting. A revegetation program has been suggested for the most severely eroded sites. 


\subsection{THE CURATION PROGRAM}

Substantial collections of artifacts have been made at the Hanford Site as a result of archaeological surveys and excavations conducted since 1968. Recent inspection of these artifacts and the associated records has shown that collections are maintained in at least five locations and are in varying conditions (Chatters et al. 1990). In 1989, the Hanford Cultural Resources Management Plan (HCRMP) recognized the need to establish a plan for the curation of these and any future collections so they could be maintained indefinitely for future scientific study or display. A first draft of such a plan was prepared in FY 1990, establishing the regulatory authorization for curation and the standards curation must meet, describing the current condition and composition of collections, offering plans for a curation facility, and suggesting the process that might be followed to transfer collections to DOE control. The plan is still under review and is not presented here. 


\subsection{EVALUATION OF KNOWN CULTURAL RESOURCE SITES FOR ELIGIBILITY TO THE NATIONAL REGISTER OF HISTORIC PLACES}

Section 110 of the NHPA and Executive Order 11593 require the DOE to evaluate all cultural resources under its management for their eligibility to the National Register. Evaluation procedures were conducted for two properties during FY 1990, and nomination documents were completed for a third. Mapping, surface collection and subsurface testing were conducted at archaeological sites 45BN90 and 45BN412. The nomination of the 100-B Reactor was completed.

\subsection{NOMINATION OE THE 100-B REACTOR}

During FY 1989, nomination forms for the 100-B Reactor were prepared and submitted to the Washington State Historic Preservation Officer for comment. Suggestions for revision were received in FY 1990 and revised documents were resubmitted. The Washington Advisory Council for Historic Preservation then considered and concurred with the nomination, which is being considered by DOE Headquarters for submission to the Keeper of the National Register.

\subsection{ARCHAEOLOGICAL SITE 45BN90}

Archaeological site 45BN90 is located near the Vernita Bridge on the right bank of the Columbia River, a location under consideration for a Washington State Department of Fisheries boat launch. Subsurface testing was required to obtain data for an assessment of the site's scientific significance to comply with stipulations of Section 106 of the NHPA. Testing took place with the assistance of a field school team from Western Washington University during June and July 1990. In addition, representatives of the Yakima Tribe visited the site on July 20 and August 8 and provided their opinions about the cultural significance of the locality.

\subsubsection{Subsurface Testing}

\section{Procedures}

Testing of 45BN90 entailed preparation of a topographic map, placement of a 10-m grid, systematic augering at 10-m intervals, and excavation of five 1- $x 2-\mathrm{m}$ test pits. Excavations were conducted in accordance with procedures specified in the HCRMP (Section 3). Artifacts were processed by the Western Washington University team and are currently being analyzed. Pits have been backfilled. 


\section{Results}

The terrace consists of massive fine and very fine fluvial sand overlying cobble gravel and capped in some cases by sand from the 1894 and/or the 1948 flood. The sand is organically stained to a depth of 40 to $50 \mathrm{~cm}$ and contains numerous fire-cracked rocks, mussel shells, and fragments of chipped stone. These materials also occur beneath the stained horizon, but in lower density. Depth of the deposits ranges from more than $150 \mathrm{~cm}$ toward the outer (north) edge of the terrace to $100 \mathrm{~cm}$ at the back of the terrace.

Artifacts occurred throughout the profile on the terrace proper but were ordinarily most abundant in the uppermost $50 \mathrm{~cm}$. Approximately 5400 pieces of chipped stone, 1600 fragments of mammal and fish bone, and 10,000 mussel shells were recovered. Preservation of bone is excellent, although most pieces are fragmented. Distinct bimodality was evident in the vertical distribution of artifacts in some excavation units on the terrace, indicating more than one period of habitation. Additionally, projectile point styles found in association with the upper mode were consistently of the stemmed style typical of the late Frenchman Springs Phase (about 2500 to 4000 years ago), whereas those found on the site surface were arrow points dating to the middle and late Cayuse Phases (the past 1000 years). Thus, at least three periods of site use appear to be distinguishable. An additional habitation of the site area may be present, as indicated by artifacts found among gravels at the bottom of several auger pits and a test pit in the slope behind the terrace. The forms of chipped stone tools found in this context, including large, leaf-shaped projectile points, may date to the Cascade/Vantage Phase (5000 to 9000 years ago).

Some horizontal patterning also occurs in the artifact distributions, although this may be simply a function of the small number of test pits excavated. Bone, shell, and fire-broken rock are more common along the back of the terrace than elsewhere. No evidence of dwelling features was found; the one feature observed was a small midden of mussel shell located at the back of the terrace. No material was recovered from which an unequivocal radiocarbon date could be obtained.

\section{Conclusion}

$45 \mathrm{BN} 90$ is a multi-component stratified habitation site that may date as early as the Cascade/Vantage Phase and certainly dates to the late Frenchman Springs and middle/late Cayuse Phases. The potential for studies of subsistence (good bone and shell preservation, occurrence of charcoal) and habitation site utilization (based on patterning) is good. 


\subsubsection{Interview of Tribal Members}

Yakima Tribe members who visited the site expressed strong concerns about excavation into the site. Philip Minthorn of the HCRL staff spoke with Lorena Sohappy, whose elders had told her how the site had been used. A longhouse (whether a mat-lodge dwelling or a ceremonial structure is unclear) was located on the terrace in the area of our excavations. West of the longhouse was a young women's house, and between the two at the back of the terrace was a cooking area (this area is where large quantities of shell, bone, and fire-cracked rock were found). Water was obtained upstream and washing took place just downstream of Liat. A sweat lodge was located farther downstream, near the slip for the old Vernita Ferry.

This site is recognized as an important place. Village sites along this reach of the Columbia River, presumably from at least Coyote Rapids upstream to Priest Rapids, were where the Washane religion started. They are associated with some of the teachings of the religion, such as ideas about where and how people originated. As such, each village site is considered to be at least as important as Coyote Rapids, where the first Washat dances were held.

\subsubsection{Assessment of Significance}

Using the criteria given in 36 CFR 60.4 for evaluation of cultural resources, site 45BN90 is significant and eligible for nomination to the National Register of Historic Places. From a scientific perspective, the site is a culturally stratified deposit with good preservation of animal remains and charcoal and can thus contribute to knowledge about subsistence, settlement patterning, and general patterns of adaptation in the Hanford reach of the Columbia River for as many as four time periods. From a cultural perspective, the site is a place of historic importance in the development of the Washane religion because of the part played by its inhabitants in developing the teachings of that religion. Therefore, the site meets criteria (a), importance to patterns of (Native American) history, and (d), importance to the scientific understanding of prehistory.

\subsection{ARCHAEOLOGICAL SITE 45BN412}

This site, which consists largely of bone and tooth fragments and large flakes of coarse stone, was discovered weathering out of an active sand dune in the fall of 1989. Because of the rate of erosion and the perishability of much of the artifact assemblage, the HCRL decided to evaluate the site during FY 1990. This work was also done with the aid of students and staff from Western Washington University under the direction of Dr. Sarah Campbell. Analysis of artifacts is still under way, but a few preliminary findings and tentative conclusions are warranted. 


\subsubsection{Data Collection}

\section{Procedures}

Work consisted of topographic mapping, surface collection, and a small amount of subsurface testing. After data were collected for the topographic map, a 5-m grid was established. Bone, teeth, and small stone ' $a k e s$ were collected by grid unit, while larger stone items and obvious tools were mapped individually. Three 1- $\mathrm{x} 2-\mathrm{m}$ test pits were excavated, using standard techniques (Chatters 1989), into less deflated parts of the dune in the hope of finding the surface from which artifacts have been eroding.

\section{Results}

Although precise counts are not yet available, approximately 1000 fragments of bones and teeth, fewer than 100 pieces of chipped stone, and fragments of 7 projectile points were recovered. Artifact categories are all closely associated spatially in a setting that does not naturally limit human activity. Therefore, it is apparent that the artifactr represent a single occupation event. Animal bones are from a variety of animals that still reside in the dune fields, but most large bone fragments and nearly all pieces of tooth are identifiable as those of bison, which were absent from the area in historic times. Numerous fragments of mussel shell were also found. Only the bison bones and mussel shells can be attributed to human agents. Stone artifacts consist primarily of large flakes of quartzite and basalt, some of which were chipped from a quartzite core found in the center of the dune. Projectile point fragments include parts of both dart and arrow points, both of which were made in a basal-notched, triangular-bladed style.

The projectile point styles and bison remains permit preliminary estimates of site age. The bow and arrow came into use around 1800 to 2000 years ago, gradually replacing the atlatl and dart (throwing stick and short spear) by around 1500 years ago (see Lohse 1985). Bison are known to have been common in the Columbia Basin between around 1600 and 2500 years ago. The site probably dates between 2000 years ago, when the bow and arrow were introduced, and 1600 years ago, after which bison were rare but during the later years of atlatl and dart usage. Tooth fragments have been submitted for radiocarbon dating to obtain an absolute age determination.

\section{Conclusion}

Site 45BN412 represents a bison kill and butchering site that was used once during the first four centuries of the Christian era. 


\subsubsection{Evaluation}

Site 45BN412 is only the second bison kill site ever found in the Columbia Basin region (Schroedl 1973). Evidence for the contemporaneity of arrow and dart technologies is also rare, so rare in fact that this site may represent the first unequivocal assocation of the competing weapon types. Given these two observations, this site has the potential to provide data of a type known nowhere else in the region. Therefore, the site is significant under criterion (d) of 36 CFR 60.4, importance to the scientific understanding of prehistory. 


\subsection{THE PUBLIC EDUCATION PROGRAM}

This activity consists of three paris: targeting elementary and middle school students, secondary school students, and the general public. The elementary and middle school effort is directed at 4th and 8th grades and will emphasize Native American cultures, archaeological interpretations, and conservation. The secondary school effort will be a part of the DOE Sharing Science with Schools program and will emphasize scientific values of cultural resources and preservation problems. The effert aimed at the general public includes 1) public relations efforts to increase awareness of cultural resources management (CRM) at Hanford, including news releases, as appropriate, and a brochure produced by the Office of Hanford Environment; 2) public lectures on CRM at Hanford and on regional prehistory; and 3) various activities related to Native American awareness.

During FY 1990, HCRL staff members spoke to 10 organizations about Native American issues and cultural resources management at Hanford. Prisentations were made to the Richland Rotary, Washington State University--Tri-Cities, Pasco Kiwanis, City of Richland Planning Commission, Lewis and Clark Days (Kennewick), the Annual Hanford Life Sciences Symposium, the Northwest Conference on Cultural Preservation (Pendleton), Unitarian Church (Kennewick), a group of visiting Native American college students, and the DOE Tiger Team. PNL's Public Relations staff, in collaboration with the HCRL, prepared a brocnure on cultural resources management at Hanford. The liberally illustrated brochure describes the Site's cultural resources, explains laws intended to protect those resources, and describes the DOE's efforts at cultural resource preservation. 


\subsection{SECTION 110 SURVEYS}

Section 110 of the NHPA specifies that federal agencies must identify all historic properties on lands under their administration. Because this requirement has rarely been practicable, given the scale of federal holdings, the Advisory Council for Historic Preservation has added to its list of acceptable identification procedures the process of predictive modeling. A predictive model estimates the number and distribution of different types of cultural resources based on either a theoretical conception of human behavior (deductive model) or a knowledge of the distribution of cultural resources on a statistically selected sample of the agency's lands (see Chatters 1989, Section 3.1.1).

The $\mathrm{RL}$ is already using a simple predictive model for conducting cultural resource reviews, in which lands have been classifíed as either low or high sensitivity, depending on their geographic setting and the likelihood that cultural resources occur in that setting. The classification is based on ethnohistorical information and on the results of archaeological reconnaissance and survey efforts previously conducted on the Hanford Site and the nearby, ecologically similar Pasco Basin. Although this model is currently in use, it has not yet been validated.

The HCRMP specifies that predictive model validation and refinement will include a $10 \%$ survey of Site lands; an analysis of the cultural properties found during that survey in temporal, functional, and distributional terms; and an extrapolation from these data of the number and distribution of different kinds of cultural resources throughout the area. This work is to be conducted during a 6-year period that started with FY 1989.

A stratified random sampling strategy has been used to select $10 \%\left(143 \mathrm{~km}^{2}\right)$ of Hanford Site lands for survey. The study area was first divided into parts (environmental zones) that were assumed or demonstrated to be internally homogeneous for environmental characteristics pertinent to human use. The characteristics considered in stratifying the area were topography, surface hydrology, soils, and known distributions of archaeological resources. Once the environments had been defined, the entire site was divided into sample units of $16 \mathrm{ha}$, which were then numbered and sampled randomly for each environmental zone. (a)

(a) The stratification and sampling procedures are documented in "Basalt Waste Isolation Project Archaeological and Cultural Resource Surveys," a 1988 letter report from the Hanford Cultural Resources Laboratory, Pacific Northwest Laboratory, to the U.S. Department of Energy Field Office, Richland, Washington. 
In FY 1990,13 plots were surveyed covering $2.08 \mathrm{~km}^{2}$, or $0.14 \%$ of the entire Hanford Site (see Appendix C). Although this is an insufficient area from which to draw conclusions, some preliminary observations are warranted. Seven plots were located in areas of high relief, such as slopes, escarpments, and buttes. These areas contained a higher proportion and variety of archaeological sites than did those located in environmental zones with generally flat and low-lying topography. The most commonly found archaeological properties in areas of high relief were prehistoric rock features, lithic scatters, isolates, and historic late nineteenth- or early twentiethcentury Euroamerican occupational remains. The combined coverage during FY 1989 and FY 1990 totals $4.64 \mathrm{~km}^{2}$, or $0.34 \%$ of Hanford Site lands. 


\subsection{ETHNOHISTORY}

An important goal set by the HCRMP--following guidelines of the American Indian Religious Freedom Act of 1978, the National Historic Preservation Act, and the Archaeological Resources Protection Act--is to establish procedures for gathering ethnographic and ethnohistorical data. This information will then be utilized to augment the RL efforts toward the protection of properties pertaining to the history and cultures of the Hanford region.

\subsection{TRADITTONAL CULTURAL PROPERTIES}

Recently, additional guidelines have been developed to assist federal agencies in determining eligibility of an identified cultural property (Parker and King 1989). In recognition of the wide range of property types, the National Register has established criteria to aid in determining whether a property may possess traditional cultural significance, therefore making it cligible for inclusion onto the National Register of Historic Places. The RL is interested in the application of National Register criteria to Hanford Site properties that otherwise may not be considered eligible using the more traditional review standards. Through ethhnohistorical research and interviews with knowledgeable tribal consultants, the RL has identified various geographic locations important to area native groups. Identified as traditional cultural properties, these localities were once occupied and used by aboriginal peoples (for centuries prior to the establishment of the Hanford Site) for gathering traditional food, medicine, and mineral resources, as well as for religious activities.

The HCRL, therefore, employs the following definitions:

- Traditional Cultural Propern - a property "defined as one that is eligible for inclusion in the National Historic Register because of its association with cultural practices or beliefs of a living community that (a) are rooted in the community's history, and (b) are important in maintaining the continuing cultural identity of the community" (Parker and King 1989, p. 2).

- Traditional Cultural Significance - "significance derived from the role the property plays in a community's contemporary but historically rooted beliefs, customs, and practices" (Parker and King 1989, p. 1).

A neccessary part in the identification of traditional cultural properties on the Hanford Site is the participation and collaboration of knowledgeable tribal consultants. Interviews are conducted by HCRL staff annually to identify knowledgeable tribal consultants willing to participate in the identification of traditional cultural properties and related topics. Information obtained as a result 
of an interview with a knowledgeable tribal consultant is considered culturally senstive consultation. Culturally sensitive consultations may be kept confidential under the authority of Section 304 of the National Historic Preservation Act. In addition to conducting interviews, research is under way to review pertinent ethnographic and ethnohistorical literature to supplement the existing HCRL data base.

\subsection{INTERVIEWS WITH KNOWLEDGEABLE TRIBAL CONSULTANTS}

In FY 1990, HCRL staff conducted preliminary interviews with four contemporary Sahaptin-speaking elders to gather information on the types of cultural properties that may be present on the Hanford Site. Background of these four elders consisted of Nez Perce, Umatilla, and Palouse affiliations. Ethnographic information relating to oral histories, traditional beliefs, and past lifeways was also solicited. Interviews took the form of an unstructured narrative with minimal questioning by the interviewer. Future interviews will be more topical to allow for a variety of descriptions and interpretations of the same subject. Also, future interviews will be documented, archived, and stored as a part of the HCRL data base. 


\subsection{REFERENCES}

Chatters, J. C., ed. 1989. Hanford Cultural Resources Management Plan. PNL-6942, Pacific Northwest Laboratory, Richland, Washington.

Chatters , J. C., and N. A. Cadoret. 1990. Archaeological Survey of the 200 East and 200 West Areas. Hanford Site. Washington. PNL-7264, Pacific Northwest Laboratory, Richland, Washington.

Chatters, J. C., N. A. Cadoret, and P. E. Minthorn. 1990. Hanford Cultural Resources Laboratory Annual Report for Fiscal Year 1989. PNL-7362, Pacific Northwest Laboratory, Richland, Washington.

Lohse, E. S. 1985. "Rufus Woods Lake Projectile Point Chronology," in Summary of Results, Chief Joseph Dam Cultural Resources Project. Washington. Edited by S. K. Campbell, Office of Public Archaeology, University of Washington, Seattle.

Parker, P. L., and T. F. King. 1989. Traditional Cultural Properties: Guidelines for Evaluation. National Register Bulletin 38, National Park Service, U.S. Department of the Interior, Washington, D.C.

Rice, D. G. 1968a. Archaeological Reconnaissance of the Ben Franklin Reservoir. Washington State University Laboratory of Anthropology, Pullman, Washington.

Rice, D.G. 1968b. Archaeological Reconnaissance of the Hanford Atomic Works. Washington State University Laboratory of Anthropology, Pullman, Washington.

Rice, D. G. 1980. Qverview of Cultural Resources on the Hanford Reservation in South Central Washington State. U.S. Department of Energy Field Office, Richland, Washington.

Schroedl, G. F. 1973. The Archaeological Occurrence of Bison in the Southern Plateau. Reports of Investigations 51, Laboratory of Anthropology, Washington State University, Pullman, Washington. 
APPENDIX A

SECTION 106 REVIEWS CONDUCTED AT THE HANFORD SITE IN FY 1990 


\section{APPENDIX A}

\section{SECTION 106 REVIEWS CONDUCTED AT THE HANFORD SITE IN FY 1990}

This appendix presents a complete listing of Section 106 cultural resource reviews requested of the Hanford Cultural Resources Laboratory (HCRL) by Hanford Site contractors and the U.S. Department of Energy Field Office, Richland (RL) during FY 1990 (Table A.1). Following this listing are descriptions of those Class V reviews completed during the fiscal year, including cases from FY 1988 through FY 1990 (Section A.2).

\section{A.1 SECTION 106 REVIEWS REQUESTED DURING FY 1990}

A complete listing of Section 106 reviews requested by Hanford Site contractors or the RL between October 1, 1989, and September 1, 1990, is presented in Table A.1. 


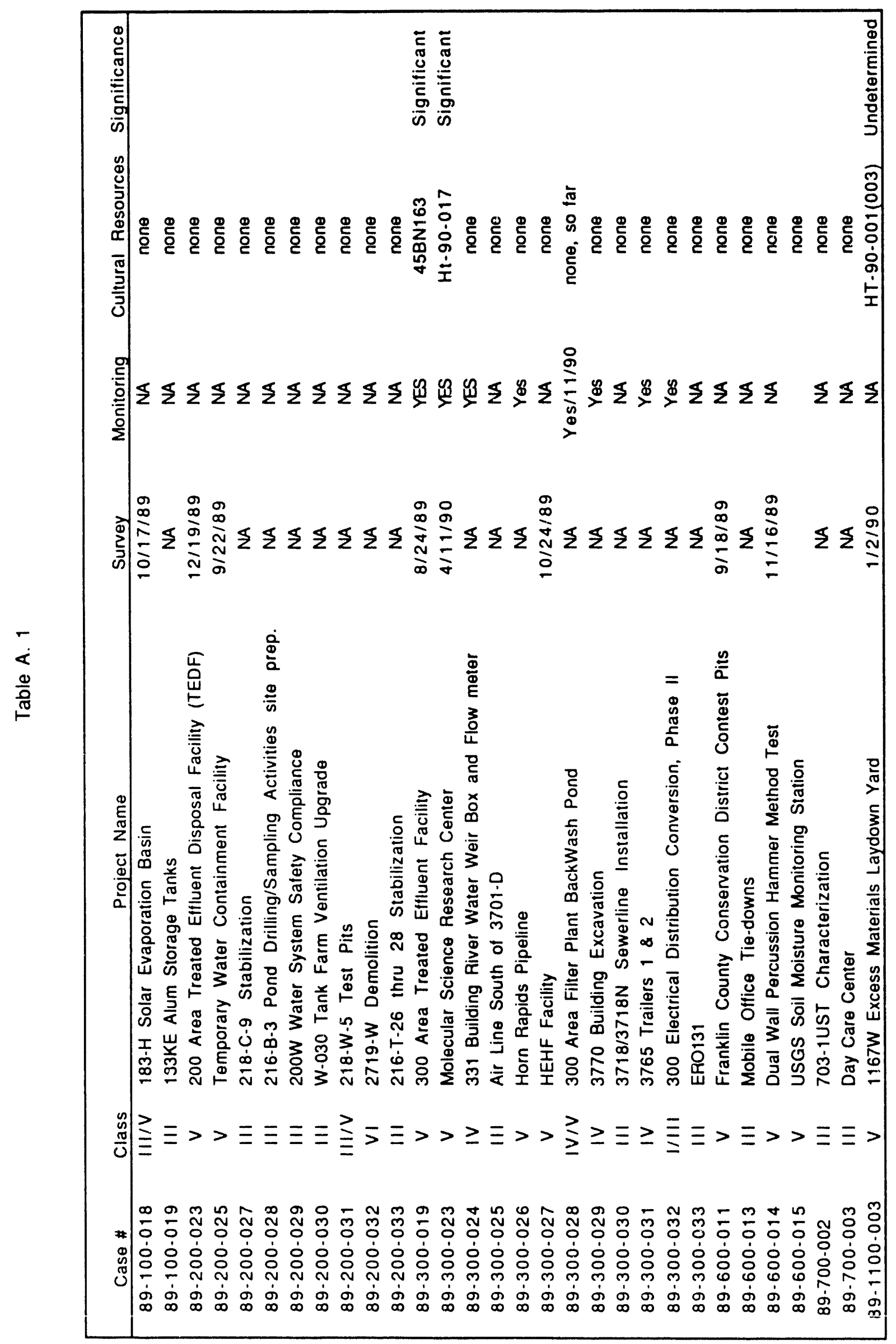

A. 2 


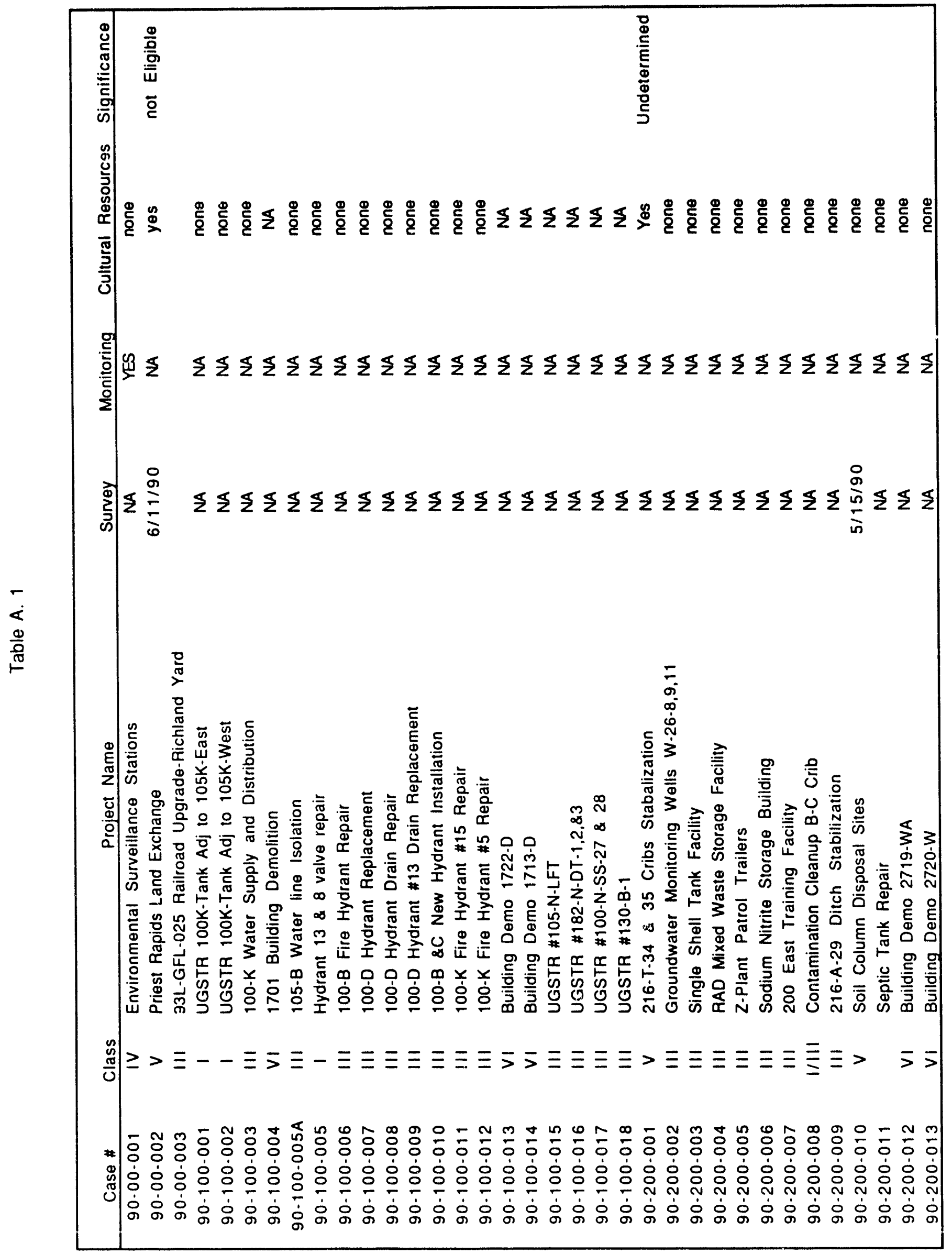

A. 3 


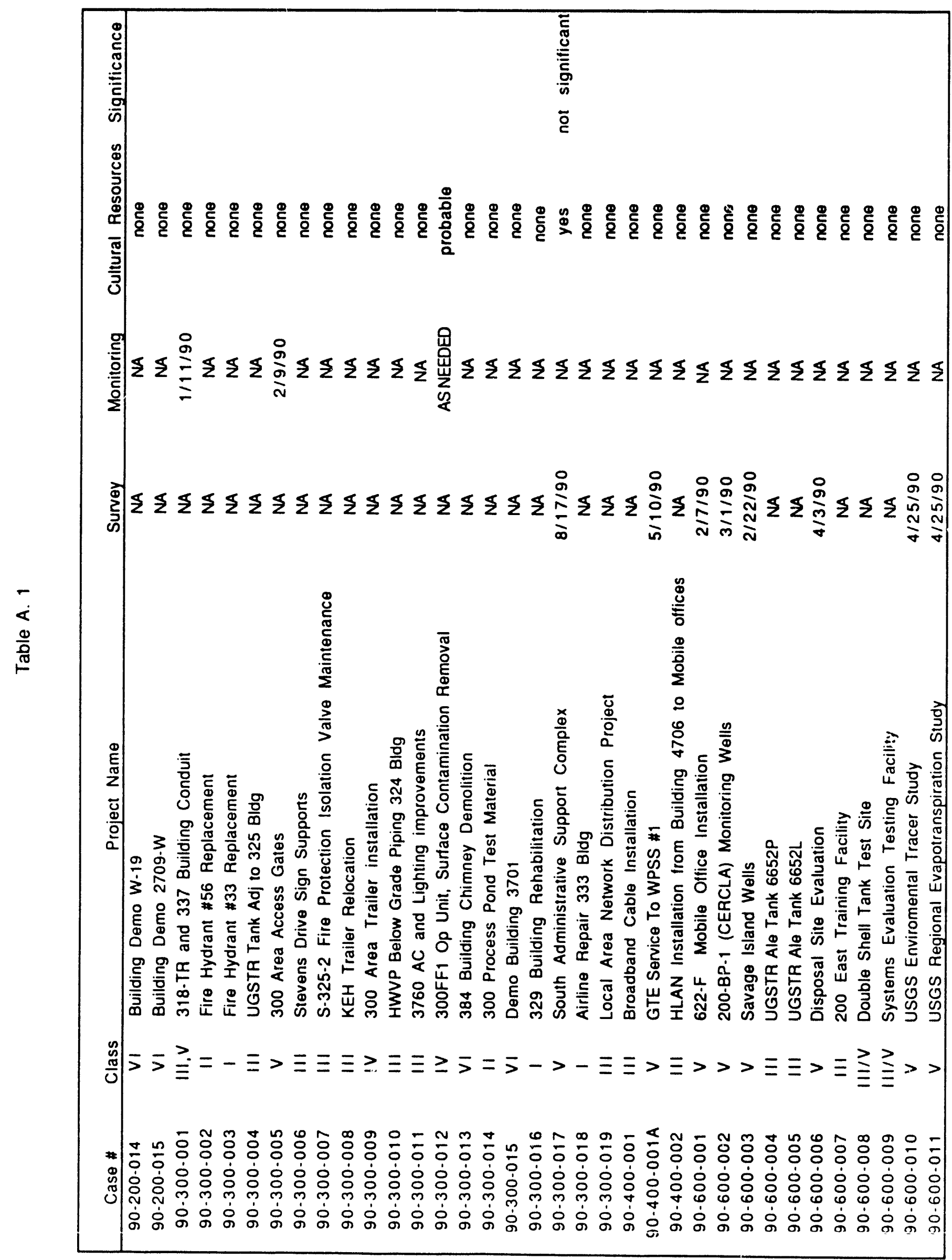

A. 4 


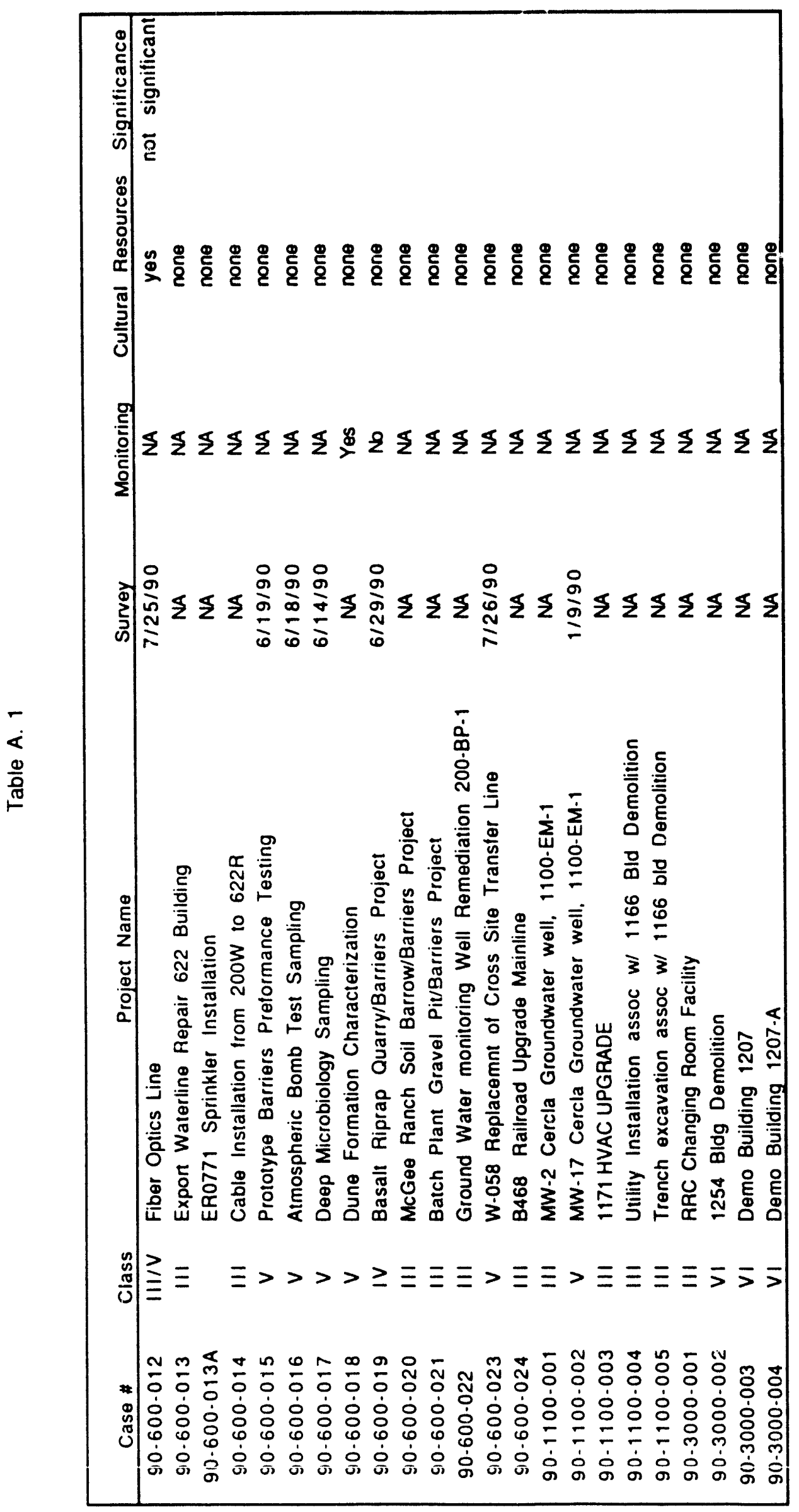

A. 5 


\section{A.2 CLASS V SECTION 106 REVIEWS}

The Class V Section 106 reviews conducted by the HCRL during FY 1990 are described on the following pages in order by Hanford Cultural Resource Case (HCRC) number. For each case, descriptions are provided for the project, the surveyed area, techniques used in the survey, and survey findings. A map of the survey area is also provided. 


\section{HCRC \#88-600-011}

\section{THE SADDLE MOUNTAIN WATER IMPROVEMENT PROJECT}

\section{Requester: R. D. Kent}

Columbia Basin Wildlife Areas

Washington State Department of Wildlife

Route 2, Box 333G

Moses Lake, WA 98837

Project Descrintion: This project entailed the construction of four water retention ponds, the erection of $15.6 \mathrm{~km}$ of wire fencing, and the installation of $11.7 \mathrm{~km}$ of buried waterline to improve grazing and wildlife habitat within the Wahluke Wildlife Area. The project area, which is on land leased to the Washington State Department of Wildlife by the U.S. Department of Energy, extends along the crest of Saddle Mountain down to its southern slope (Figure A.1).

A literature and records review demonstrated that no archaeological or Native Americari cultural properties were known to be located within the project boundaries. Areas in the vicinity of the proposed retention ponds had been previously surveyed (Chatters 1989); however, the pipeline and fenceline corridors had not. Because the entire project area was situated on undisturbed ground, pedestrian surveys were required before the project could be cleared. J. C. Chatters inspected the four pond sites on December 6, 1988. The waterline and fenceline corridors were surveyed by P. E. Minthorn between September 19, 1989, and January 14, 1990. Because of the linear nature of these improvements, only a single transect was used, with a 10-m area on either side carefully inspected. All distinct topographic features located near the project boundaries were also closely inspected.

Cultural Resources: No cultural properties were found within or in the vicinity of the four water retention ponds. Fourteen prehistoric sites were recorded along or in the vicinity of the waterline and fenceline corridors; eight of these sites appeared likely to receive direct impacts from construction activities. Temporary designations, descriptions, and the areas of these properties are listed in Table A.2. For those sites that may receive impacts, the preferred mitigation alternative of the HCRL is avoidance, and this recommendation has been transmitted to the requesting agency. The acceptance of this recommendation or the development of acceptable alternatives has yet to be negotiated. 


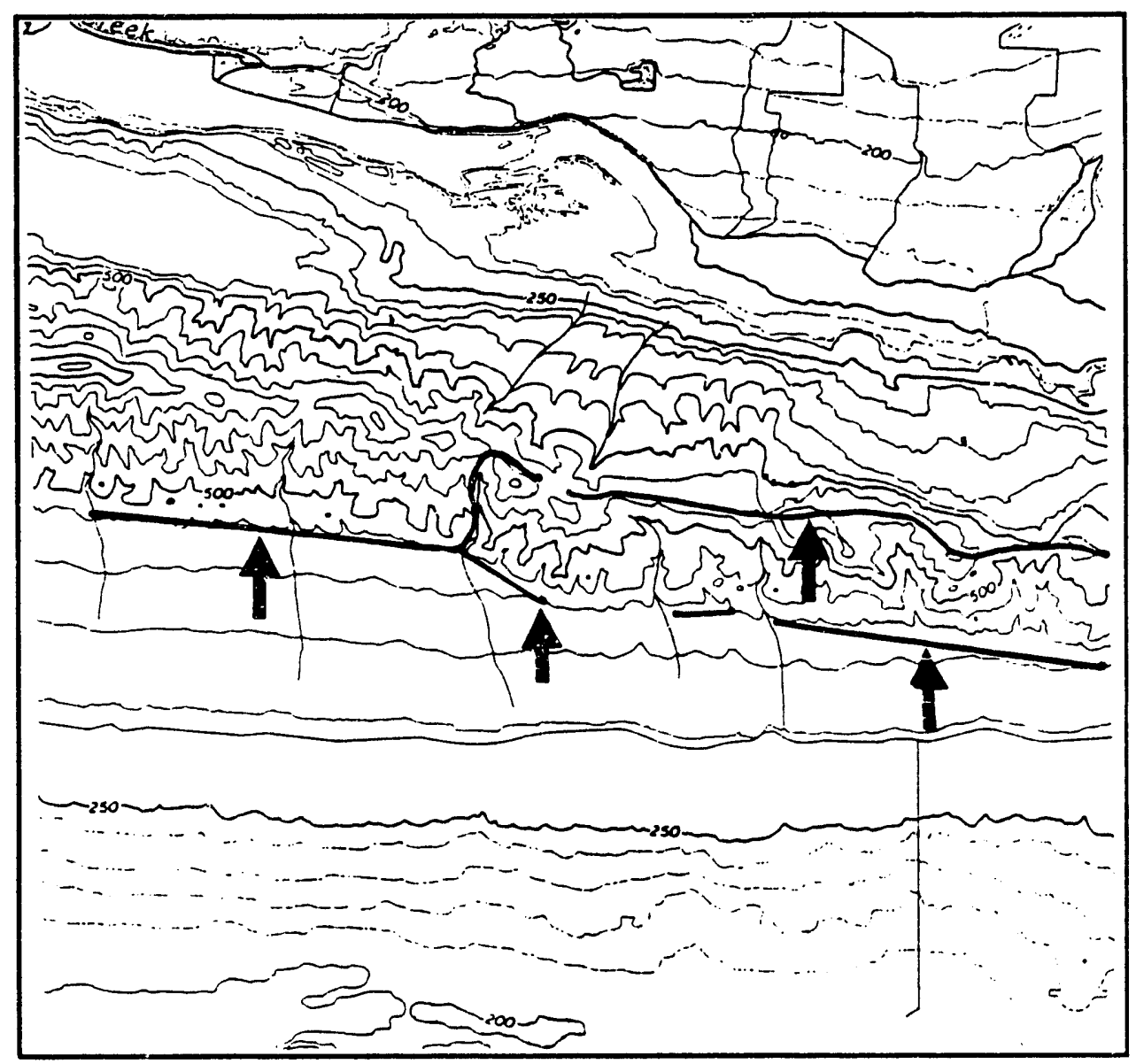

FIGURE A.1. Location of the Area Reviewed (heavy line) for the Saddle Mountain Water Improvement Project, HCRC \#88-600-011, on a Portion of the U.S. Geological Survey (USGS) Map for Priest Rapids, Washington, (contour interval $50 \mathrm{~m}$ ) 
TABLE A.2. Cultural Sites Recorded During Surveys for the Saddle Mountain Water Improvement Project

Site Number

HT-89-018*

HT-89-019*

HT-89-020*

HT-89-021

HT- $89-022 *$

HT-89-023*

HT-89-024

HT-89-025*

HT-89-026*

HT-89-027*

HT-89-028

HI-89-013

HI-89-014

HI-89-015
Description

Size. $\mathrm{m}^{2}$

Sparse lithic scatter, 5 CCS flakes

10

Lithic scatter, 100+ CCS flakes

50

Rock cairn; basalt, 2 CCS flakes assoc.

Rock cairn; basalt

Sparse lithic scatter, 3 CCS flakes

Rock cairn; red basalt, pos. burial

Rock cairn; basalt

Lithic scatter, $100+$ CCS flakes

Lithic scatter, $1000+$ CCS flakes

Lithic scatter, 100+ CCS flakes

Rock cairn; assoc. solarized bottle frag.

Isolate; CCS flake

Isolate; CCS flake

Isolate; CCS flake
20

5

10

10

10

100

500

100

10

NA

NA

NA

*These sites may be impacted by construction. Avoidance has been recommended. 


\section{HCRC \#89-100-018}

\section{3-H SOLAR EVAPORATION BASINS SOIL SAMPLING}

\section{Requester: A. D. Krug}

Environmental Engineering Group

Environmental Division

Westinghouse Hanford Company

Richland, WA 99352

Project Description: Nine soil samples outside of the 183-H solar evaporation basins were to be collected to gather radiological background information. The samples came from an undisturbed area outside of the 100-H security fence, in a region suggested by our literature and records potentially to contain prehistoric archaeological sites (Figure A.2). Although no sites had been recorded in the $46-\mathrm{m}^{2}$ area identified for sampling, several sites had been located within several hundred meters of the area; therefore, a pedestrian survey was necessary prior to any ground disturbing activity. N. A. Cadoret surveyed the area on November 10, 1989, utilizing standard survey techniques. Ground visibility was reported to be $70 \%$.

Cultural Resources: No cultural resources were located in the project area. 


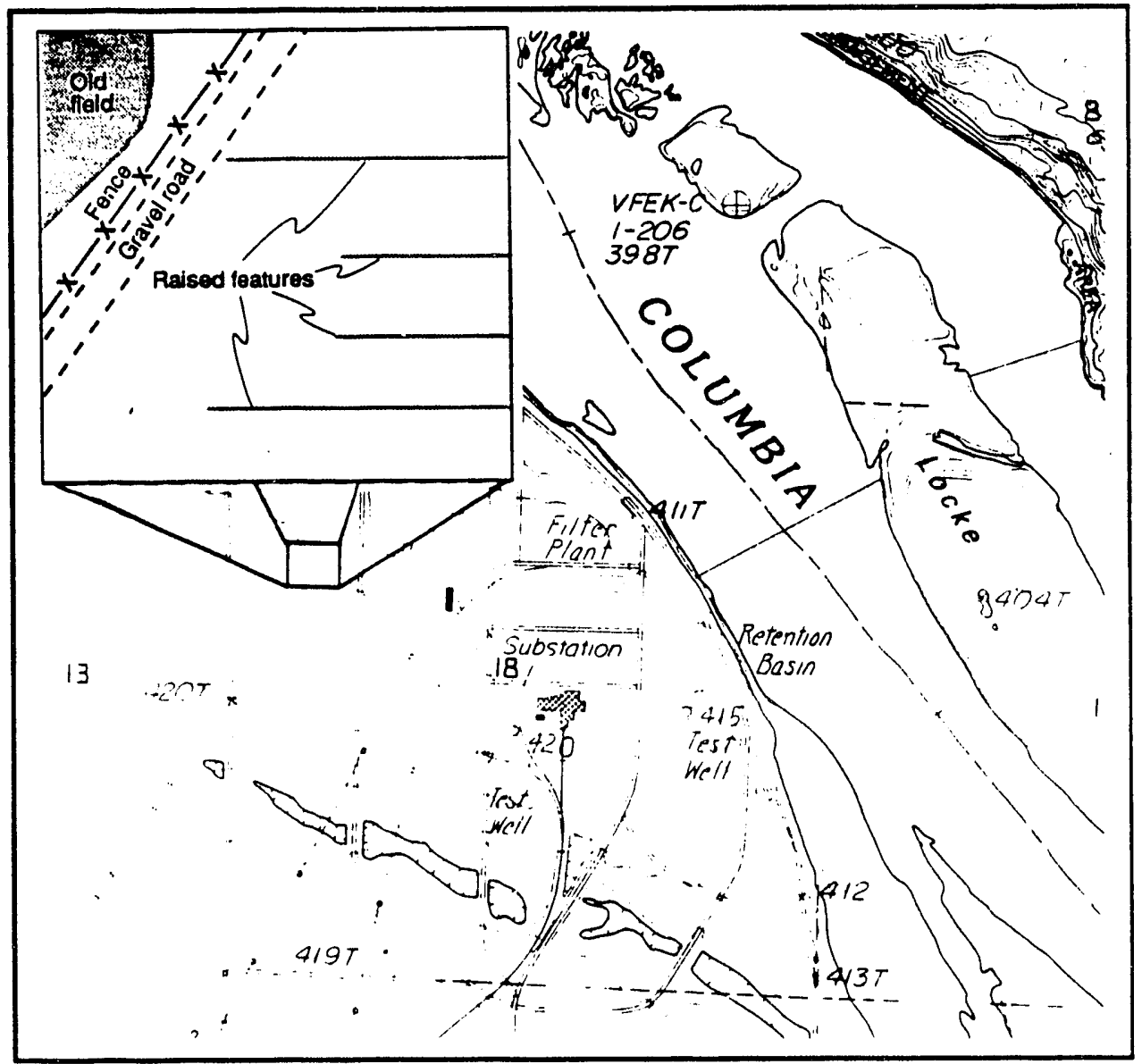

FIGURE A.2. Location of the Area Reviewed (inset) for the 183-H Solar Evaporation Basins Soil Sampling, HCRC \#89.100-018, on a Portion of the USGS Map for Locke Island Quadrangle, Sec. 18 T14-R27E 


\title{
HCRC \#89-200-023
}

\section{AREAS TREATED EFFLUENT DISPOSAL FACILITIES}

\author{
Requester: E. T. Trost \\ Site Planning Group \\ Westinghouse Hanford Company \\ Richland, WA 99352
}

Project Description: An area of approximately 275 acres is to be developed northeast of the 200 East Area (Figure A.3). Proposed facilities within this parcel of land include the Effluent Retention and Treatment Facilities (ERTF), the Liquid Effluent Retention Facility (LERF), and the Purge Water Projects. Additionally, $29 \mathrm{~km}$ of pipeline is proposed for construction. Two pipelines will extend between the 200 East and 200 West Arca a third pipeline, designated the East River Disposal Option (ERDO), may also be built extending from the ERTF to the Columbia River.

The proposed project site is located in predominantly undisturbed ground that had not been previously surveyed for cultural properties. A literature and records review showed that two archaeological sites are in the near vicinity of the proposed project. In the 200 West Area, a segment of the pipeline route intersects the historic White Bluffs Road, and at the river's edge, where the ERDO outfall area terminates, is archaeological site 45BN307.

P.E. Minthorn and N.A. Cadoret conducted a pedestrian survey of the project area between November 7, 1989, and January 10, 1990, using a 20-m transect interval. When archaeological properties were encountered, the survey was intensifier to locate the approximate boundaries of each site. Average ground cover during the survey was approximately 30 to $40 \%$.

Cultural Resources: No cultural properties were identified in the area designated for the Effluent Retention and Treatment Complex (ERTC). Survey results did reveal four prehistoric sites and one isolated artifact in the immediate vicinity of the proposed pipeline routes. Within the ERDO area, two archaeological sites were recorded and were designated HT-89-029 and HT-90-002. HT-89-029 is a Quilomene Bar Phase site with an age range of 150 to 3000 years ago and consists of a scatter of mammal bone fragments, fire-cracked rock, and one chronologically diagnostic projectile point. HT-90-002 is an aboriginal trail extending $140 \mathrm{~m}$ in a northeast/ southwest direction.

One archaeological site (HT-89-030) was recorded within the northern pipeline route that extends between the 200 West and 200 East Areas; the site consists of a large, angular, basalt rock cairn. On the southern portion of the pipeline connecting the 200 West and 200 East Areas, one 


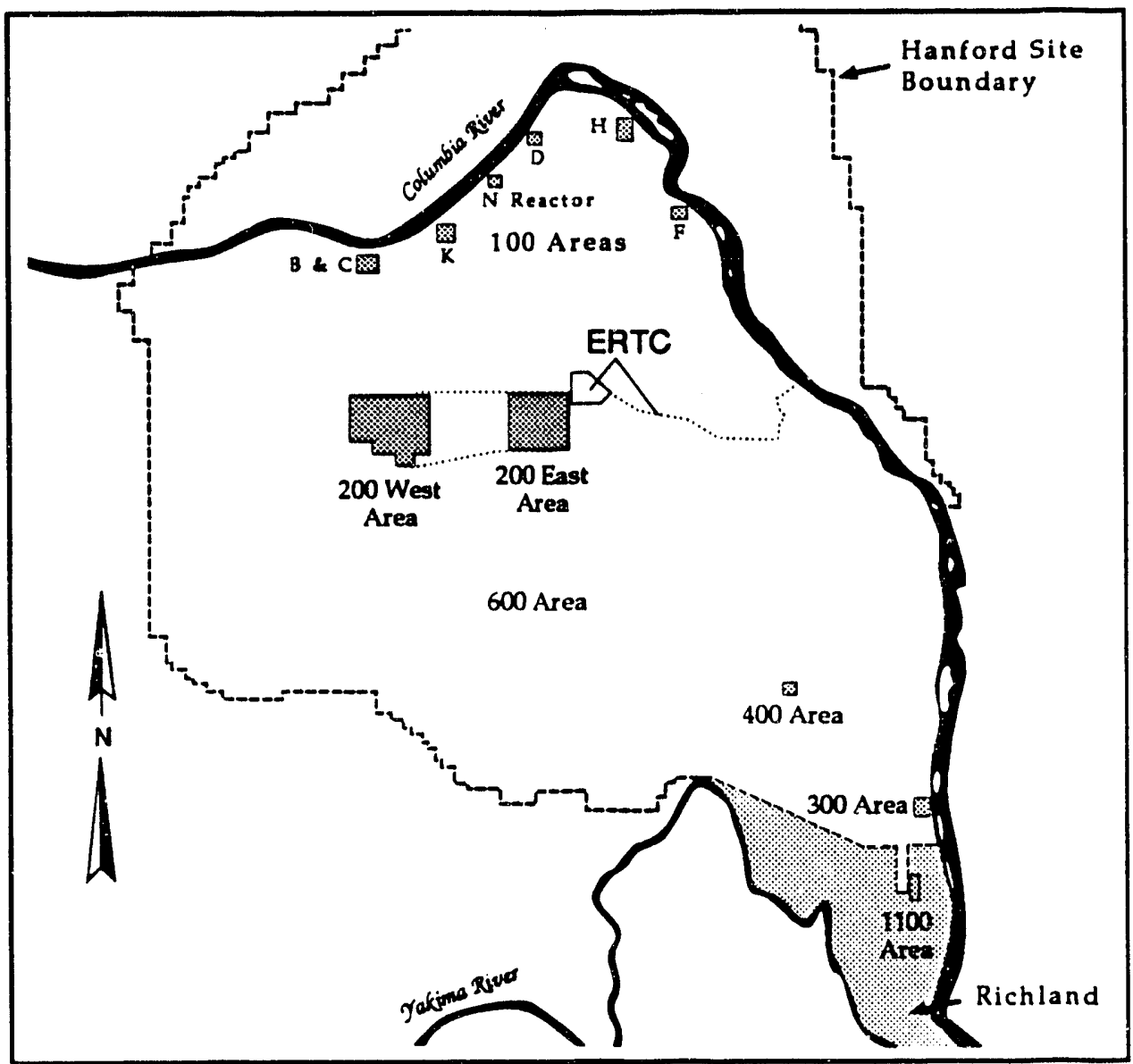

EIGUREA.3. Location of the Area Reviewed for the 200 Areas Treated Effluent Disposal Facilities, Including the Effluent Retention and Treatment Complex (ERTC) and Associated Pipeline Routes, HCRC \#89-200023, on a Portion of an HCRC Site Map (November 1990) 
archaeological site (HT-89-031) and one isolated artifact (HI-89-016) were recorded. HT-89-031 is a small concentration of fire-cracked rock and mammal bone fragments; HI-89-016 is a cobble tool.

Of the two previously recorded sites, the historic White Bluffs Road meets eligibility criteria for nomination to the National Register of Historic Places and is accorded certain protective measures. To prevent negative impacts to the White Bluffs Road, a culturally sensitive zone was established, extending for $100 \mathrm{~m}$ on either side of the road. Procedures now require that all personnel involved in ground disturbing activities are to be alerted to this culturally sensitive zone and that, for all proposed projects, appropriate allowances are to be made to minimize any impacts to the road and the surrounding area.

Archaeological site 45BN307 is considered potentially eligible for nomination to the National Register of Historic Places. This status is based on the nature of the archaeological materials within the site and how those materials relate to other archaeological sites in the area. Exploratory excavations at 45BN307 revealed a previously undisturbed prehistoric deposit, possibly representing a Cayuse Phase occupation, which dates from approximately 1500 A.D. to the historic period (ERTEC 1982). A reanalysis of the recovered material, however, suggests that this conclusion may be incorrect and that the site is actually associated with late Frenchman Springs Phase (2800 to 3500 years ago) and Cascade/Vantage Phase (5000 to 9000 years ago) manifestations. Reconnaissance through the site for this project further substantiated this interpretation by locating a Cascade Phase artifact. Further evaluation is required. Because the site retains considerable integrity and contains two distinct cultural components, exploratory excavation and mitigation of impacts will be necessary if the ERDO is selected. Additionally, a report on our findings to the State Historic Preservation Office will be necessary before the East River Disposai Option can proceed in its currently identified location.

Of the sites recorded during the survey for this project, all appear to be superficial in nature and to encompass relatively small areas, suggesting a brief occupational time span. Prehistoric sites HT-89-029, HT-89-030, HT-89-031, and HT-90-002 appear in direct line with, or on the peripheral margins of, the proposed pipeline route for the ERDO. Each of these sites will require further evaluation to determine the appropriate protective measures. Isolated artifact HI-89-016 will be collected, and no protective measures for this area will be necessary.

Because no historic properties were identified in the parcel of land designated for the Effluent Retention and Treatment Complex adjacent the 200 East Area, this portion of the project was 
cleared of cultural resource concerns. Further evaluation is required for those sites within the ERDO, and our evaluation must be completed before the project may proceed in those locations. The status of the East River Disposal Option is as yet unknown. 
HCRC \#89-200-025

\section{TEMPORARY GROUNDWATER CONTAINMENT TANKS}

\section{Requester: C. E. Hodge}

Environmental Projects

Defense Waste Management

Westinghouse Hanford Company

Richland, WA 99352

Project Description: The installation of four above-ground, modular, 3.79-million-L storage tanks disturbed an area of approximately $41,000 \mathrm{~m}^{2}$ east of the 200 East Area to a depth of $1.5 \mathrm{~m}$ (Figure A.4). An area measuring $150 \mathrm{~m}$ by $100 \mathrm{~m}$ was previously undisturbed, and, therefore, a cultural resource survey was required before construction could take place. A review of literature and records showed that no archaeological sites or culturally important properties were known to be located in the project area. On September 22, 1989, N. A. Cadoret surveyed the area using standard field techniques.

Cultural Resources: No cultural properties were observed within the undisturbed portion of the project area. 


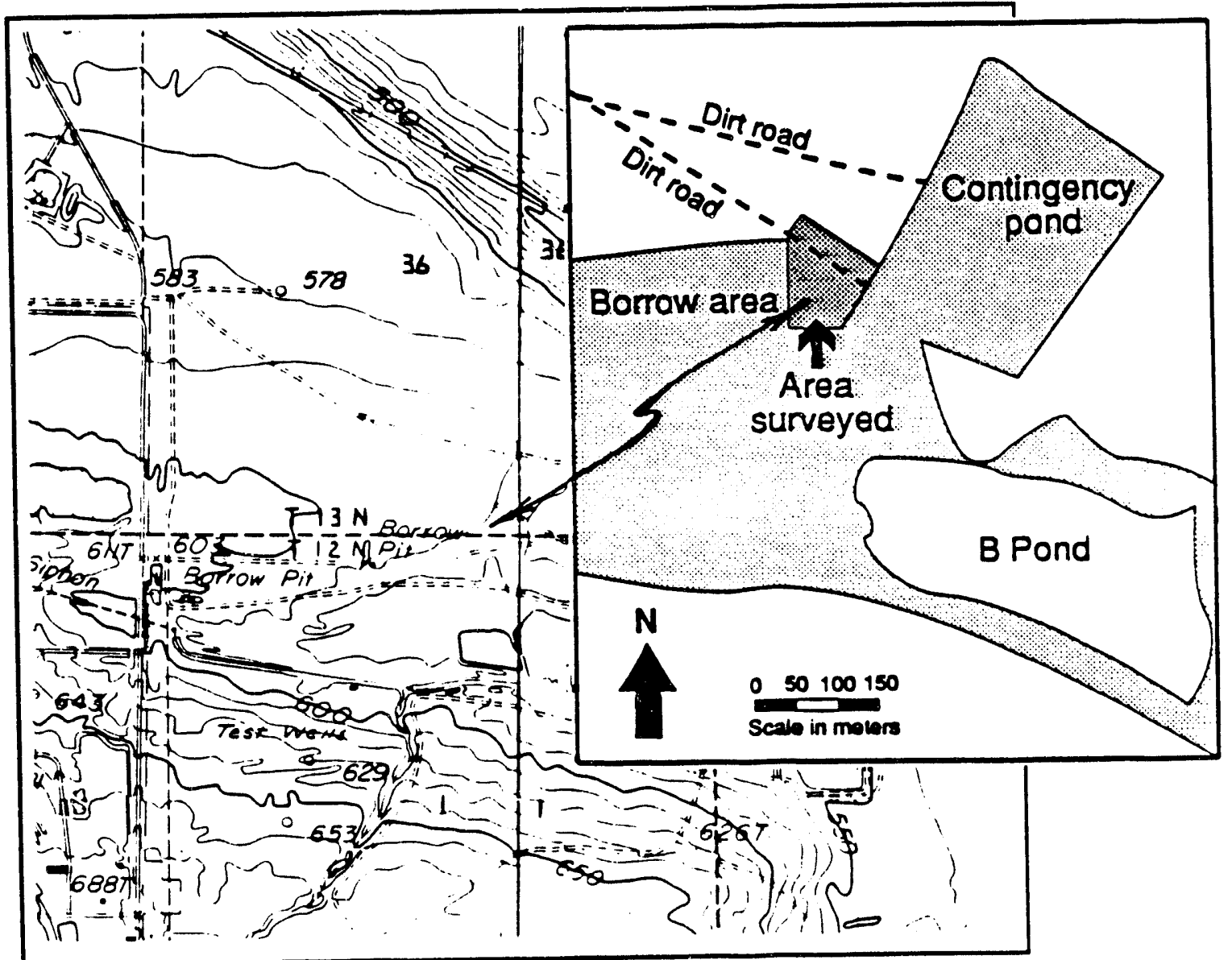

FIGURE A.4. Location of the Area Reviewed (see inset) for the Temporary Groundwater Containment Tanks, HCRC \#89-200-025, on a Portion of USGS Gable Butte and Hanford Quadrangles, Sec. 1 T12-R13N 
HCRC \#89-300-019

\section{AREA TREATED EFFLUENT DISPOSAL FACILITY (TEDF)}

\section{Requester: S. W. Seiler \\ Site Support \\ Operations Support Services \\ Westinghouse Hanford Company \\ Richland, WA 99352}

Project Description: This project entails the construction of a 20-acre effluent retention and treatment facility north of the 300 Area (Figure A.5). Excavations are projected to reach $9.1 \mathrm{~m}$ in depth. Two separate options are still under consideration for disposal of the treated effluent, construction of a storage crib, adjacent to the north end of the retention ponds, or an outfall line extending from the retention facility to the Columbia River.

A literature and records review showed that one significant archaeological site is located in the vicinity of the project area. Archaeological site 45BN163 is a multi-component, stratified, prehistoric village site, with evidence of human graves. It was previously determined eligible for nomination to the National Register of Historic Places based on the site's scientific potential, as well as its possible sacred standing because of the presence of human remains.

The areas identified for the retention facility, and crib and outfall options were surveyed by $P$. E. Minthorn of the HCRL on August 24 and 25, 1989. Standard field techniques were used to ensure adequate surface coverage.

Cultural Resources: No cultural material was noted in the vicinity of either the retention facility or the crib option. Subsurface testing of Site 45BN163, conducted in 1987, indica.ed that buried material does not extend west beyond the dirt road that parallels the Columbia River along the bank. Numerous artifacts and discrete surface features were recorded, however, within the proposed outfall line corridor east of the road.

The construction of the sewage retention facility will not directly impact the archaeological site in question, provided the construction activities are confined to the west side of the dirt road mentioned above. However, indirect impacts may occur, resulting from increased numbers of personnel in the vicinity of the site, heightening the probability of unauthorized surface collection and/or vandalism. Installation of the outfall option, as it is currently planned, will directly impact the site.

The HCRL has made several requirements and recommendations concerning the construction of the TEDF. To prevent indirect impacts to the site, access to the river bank east of the road should be restricted by signing the area off limits, informing personnel that the signs are to be taken 


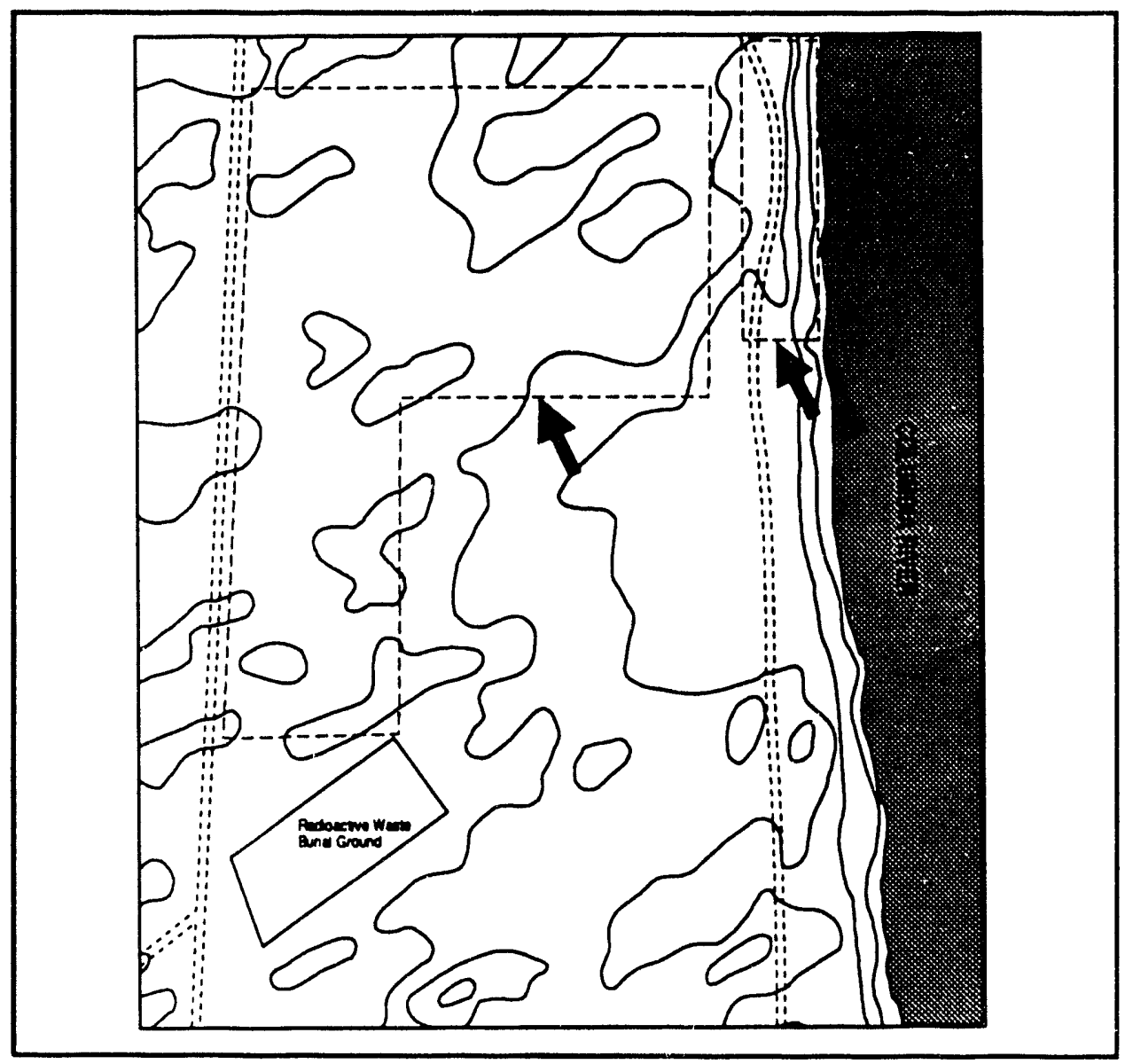

EIGURE A.5. Location of the Area Reviewed (within dashed lines) for the 300 Area Treated Effluent Disposal Facility (TEDF), HCRC \#89-300-019, on a Portion of an HCRL Site Map (November 1990) 
seriously, and periodically monitoring restriction compliance. To ensure that no human remains are inadvertently disturbed by construction, excavations for the retention facility, and, if selected, the crib option should be periodically monitored by an HCRL archaeologist. Finally, if the outfall option is selected, impacts to the site will need to be mitigated through data recovery. Less expensive and time-consuming alternatives, which are preferred by HCRL staff, are to select the crib option for effluent storage or to relocate the outfall line farther upstream. If the outfall line is relocated north to a point beyond the boundaries of site $45 \mathrm{BN} 163$, then only monitoring of excavations in that area will be required.

This project is still in the site planning stage and final determinations as to option selections, construction scheduling, and decisions regarding the disposition of Site 45BN163 have yet to be made. 
HCRC \#89-300-023

THE ENVIRONMENTAL AND MOLECULAR SCIENCES LABORATORY

Requester: $\quad M$. T. Thomas

Molecular Science Research Center

Pacific Northwest Laboratory

Richland, WA 99352

Project Description: This project involves the location of the proposed Environmental and Molecular Sciences Laboratory that was to be erected between George Washington Way and Stevens Drive on the north side of Horn Rapids Road (Figure A.6). Construction of the new facility would have impacted a 10.5-ha (26-acre) area, with excavations for footings and utilities measuring between 0.9 and $1.8 \mathrm{~m}$ in width. The location of the facility has subsequently been changed.

A review of records and applicable literature did not reveal the presence of any known archaeological or Native American cultural properties. However, because the area was largely undisturbed, a pedestrian survey of the project area was required prior to the beginning of construction. P. E. Minthorn surveyed the area on August 31, 1989, using standard survey methods. The area was reinspected on March 20, 1990, by P. E. Minthorn and H. A. Gard.

Cultural Resources: Two historic sites (temporarily designated as HT-89-016 and HT-89-017) were recorded, and, based on temporally diagnostic artifacts, both appeared to date from the late nineteenth or early twentieth century. HT-89-016 is a light-density, widely dispersed artifact scatter, while HT-89-017 is a discrete concentration of synchronic debris that appears to be the result of a single depositional episode. Based on the predominance of household items, HT-89-017 appears to be the remains of a homestead. The remains of an old road or dirt track connect the two sites, raising the possibility that the sites actually represent two separate loci within a larger complex, such as a farm with outlying structures. Neither the road nor evidence of structures is present on 1868 Government Land Office Survey maps, indicating that the sites postdate that survey. Preliminary conclusions are that HT-89-017 may be eligible for nomination to the National Register of Historic Places as representative of an early regional homestead, while HT-89-016 is not eligible because it lacks the integrity and information potential of the other site. Fortunately, neither site would have been directly impacted by construction of the new facility. To prevent inadvertent damage from machinery, equipment storage, traffic, etc., the sites were to have been flagged prior to the commencement of construction activities. 


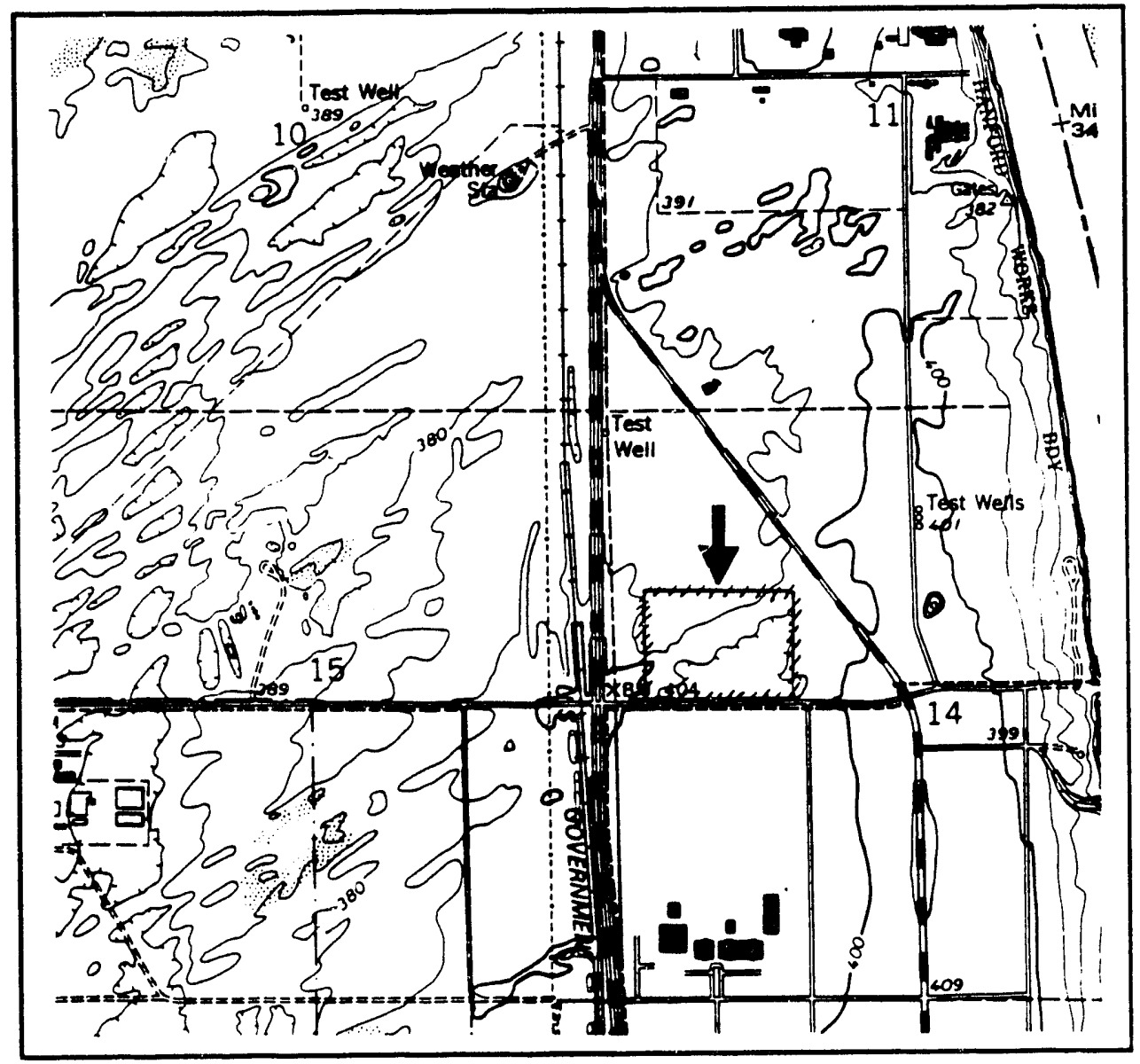

FIGURE A.6. Location of the Area Reviewed (within hatched lines) for the Environmental and Molecular Sciences Laboratory, HCRC $\# 89-300-023$, on a Portion of the USGS Richland Quadrangle, Sec. 14 T10N-R28E 
HCRC \#89-300-024

331 BUILDING RIVER WATER WEIR BOX AND FLOW METER

Requester: D. A. Koontz

Facilities Engineering

Pacific Northwest Laboratory

Richland, WA 99352

Project Descriotion: On the east side of the 331 Building, within the 300 Area, a replacement river flow meier and associated weir were necessary to replace a faulty unit (Figure A.7). Installation required that a $1.8-\mathrm{m}^{2}$ area be excavated to a depth of $1.5 \mathrm{~m}$. Literature and records did not reveal the presence of any known cultural properties within the project area. Although the flow meter was to be installed in a previously disturbed area, proximity to the sensitive river bank necessitated the presence of an HCRL archaeologist during excavations.

Cultural Resources: At the time of this writing, the contractor has yet to begin the project. 


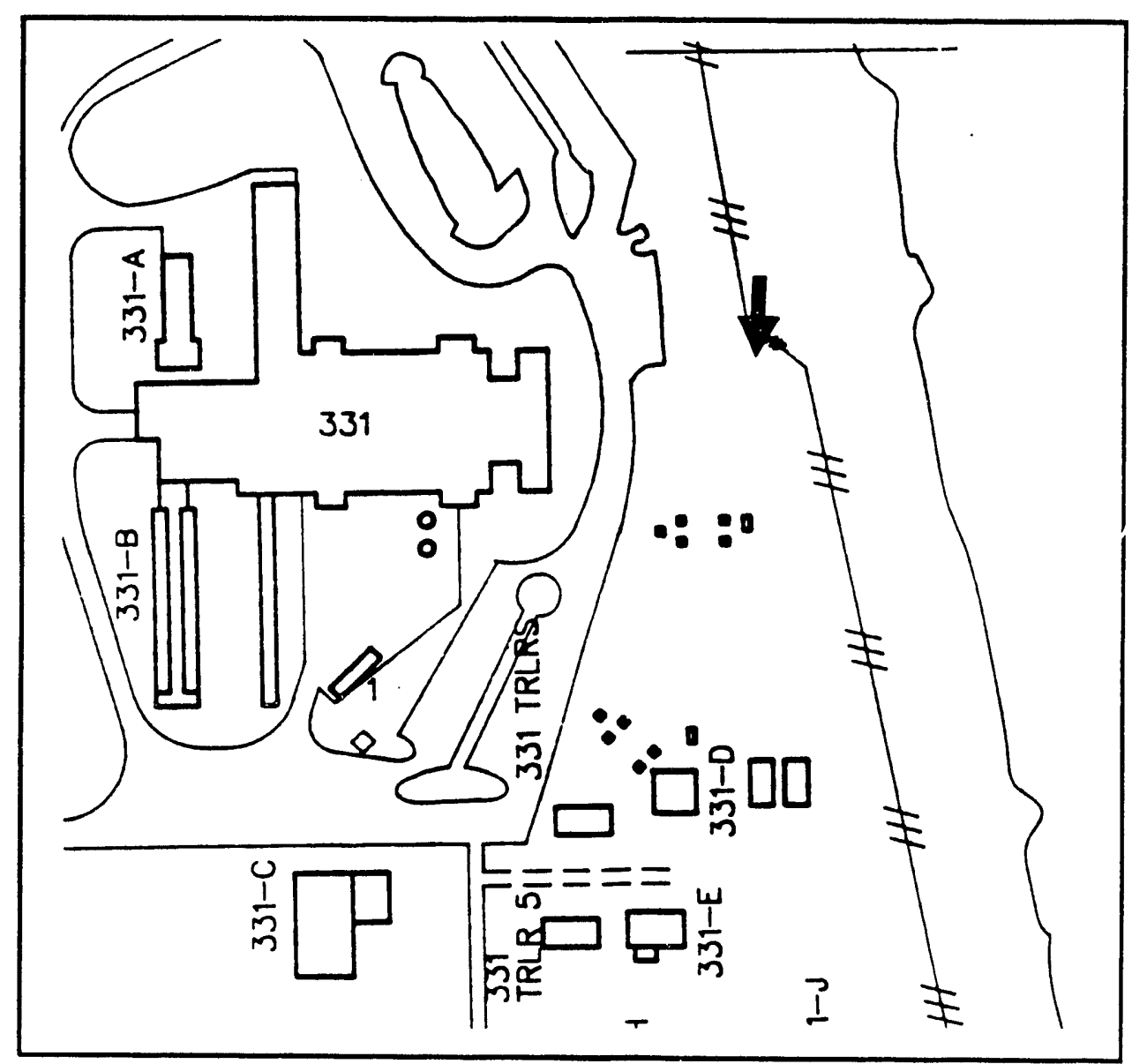

FIGURE A.7. Location of the Area Reviewed for the 331 Building River Water Weir Box and Flow Meter, HCRC \#89-300-024, on a Portion of a 300 Area General Layout Map (October 1987) 
HCRC \#89-300-026

\section{HORN RAPIDS IRRIGATION PIPELINE}

Requester: S. L. Jones

Site Management Division

U.S. Department of Energy

Field Office, Richland

Richland, WA 99352

Project Description: During April and May 1990, a 0.9-m-diameter waterline was constructed, extending westward from the Columbia River, paralleling the north side of Horn Rapids Road to the west side of the railroad tracks adjacent to Stevens Drive, and from that point extending southwest to the Hanford Site boundary in Section 22 (Figure A.8). Because this project would impact the river bank (considered a sensitive area), as well as uncisturbed ground, a pedestrian survey was required prior to the commencement of construction activities. A review of literature and records showed that one archaeological site, 45BN104, considered eligible for nomination to the National Register of Historic Places, was located within $200 \mathrm{~m}$ of the pipeline along the river. P. E. Minthorn and N. A. Cadoret surveyed the pipeline corridor on October 16 and 17, 1989.

Cultural Resources: Several artifacts were recorded within $50 \mathrm{~m}$ north of the pipeline corridor. Because of these, and because all areas within $400 \mathrm{~m}$ of the river are considered sensitive, monitoring of pipeline excavations within this sensitivity zone was required. P. E. Minthorn monitored installation of the pipeline on January 3,1990, and J. C. Chatters inspected the trench after excavation. No cultural resources were encountered. 


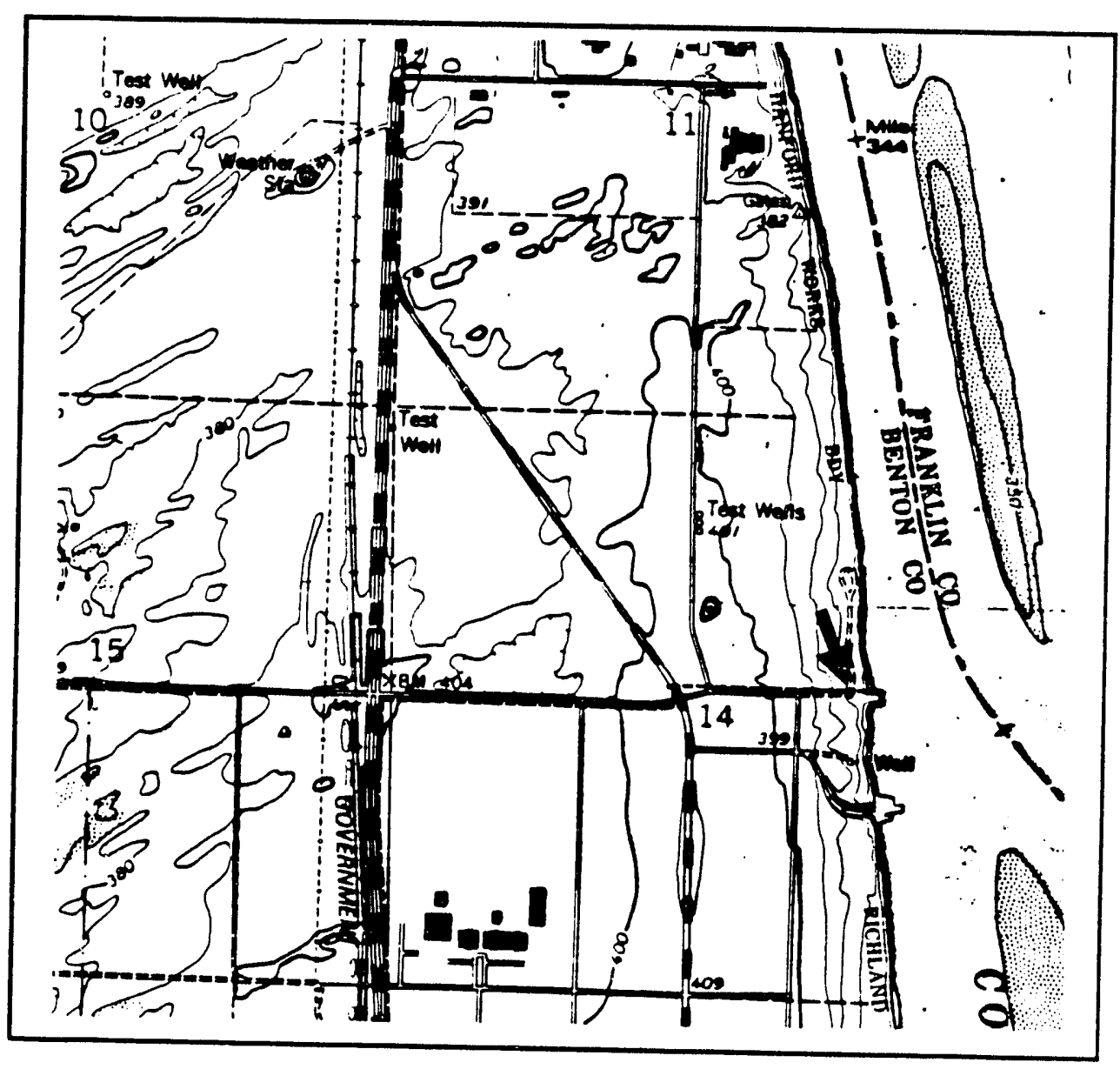

FIGURE A.8. Location of the Area Reviewed for the Hom Rapids Irrigation Pipeline, HCRC \#89-300-026, on a Portion of the USGS Richland Quadrangle, SEC. 14 T10N-R28E 
HCRC \#89-300-027

HANFORD ENVIRONMENTAL HEALTH FOUNDATION-ENVIRONMENTAL HEALTH SCIENCE FACILITY

Requester: K. S. Daly

Site Planning Group

Westinghouse Hanford Company

Richland, WA 99352

Project Description: The new Hanford Environmental Health Foundation-Environmental Health Science (HEHF-EHS) Facility, situated on the northwest juncture of Horn Rapids Road and George Washington Way, is being constructed on undisturbed ground, and, therefore, a cultural resource survey was required before construction could begin. The project would impact a 5-acre area (Figure A.9). A review of literature and records showed that no archaeological sites or culturally important properties were known to be located in the project area. On November 10 , 1989, P. E. Minthorn surveyed the area using standard field techniques.

Cuitural Resources: Aside from some neoteric debris, not considered significant under federal regulations, no cultural properties were observed within the project area. 


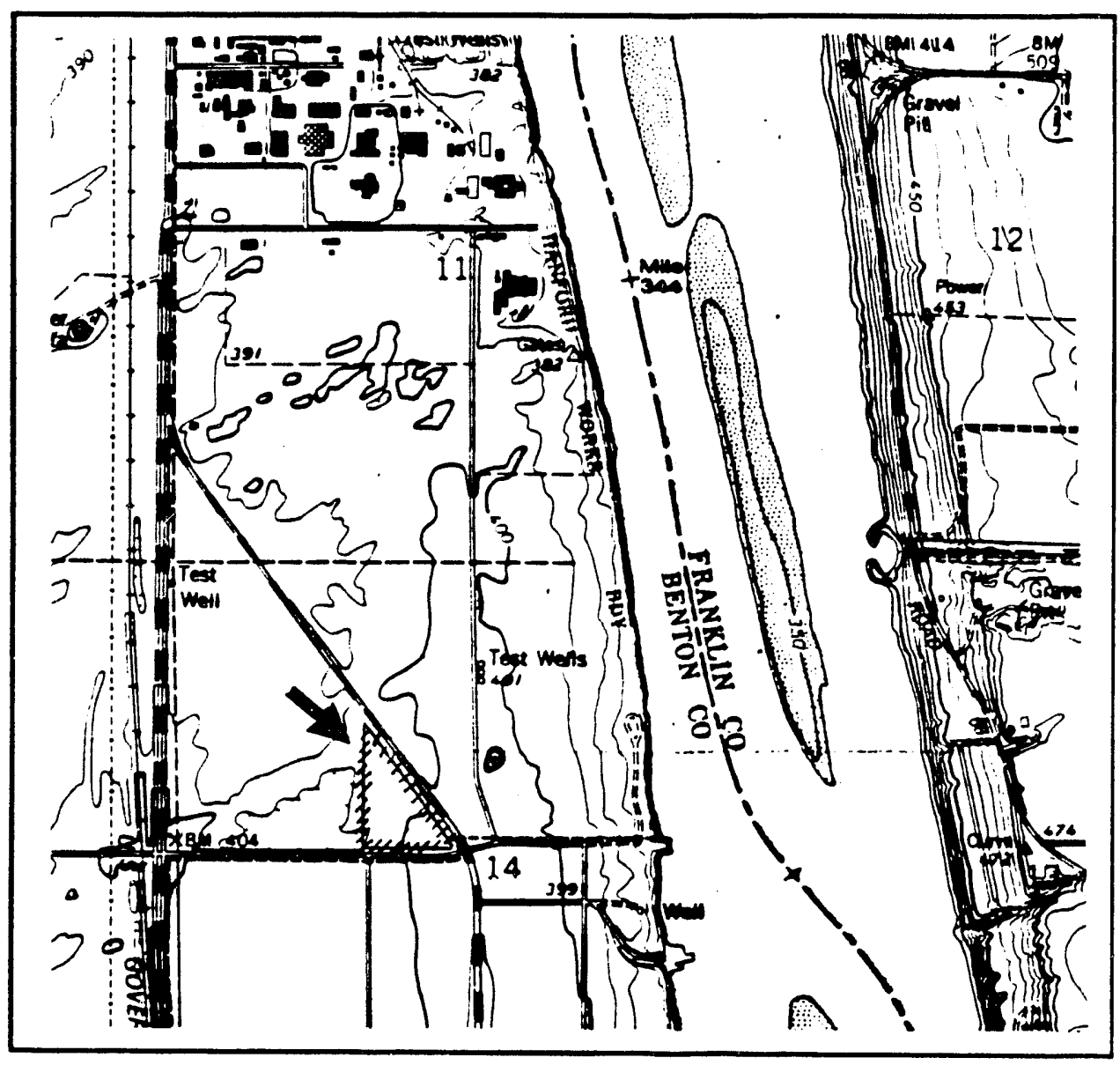

FIGURE A.9. Location of the Area Reviewed (within hatched lines) for the HEHF-EHS Facility, HCRC \#89-300-027, on a Portion of the USGS Richland Quadrangle, Sec. 14 T10N-R28E 
HCRC \#89-300-028

\section{AREA FILTER PLANT BACKWASH POND}

Requester: D. L. Pursley

Nuclear Energy Projects

Westinghouse Hanford Company

Richland, WA 99352

Project Description: A Filter Plant Backwash Pond is currently under construction north of the 315 Building (Figure A.10) in the 300 Area of the Hanford Site. The final lined sedimentation pond will measure $52 \mathrm{~m}$ by $97.5 \mathrm{~m}$ and will be $6 \mathrm{~m}$ deep. Literature and records did not reveal the presence of any known cultural properties within the project area. However, because this project was to take place both in a sensitive area, within $400 \mathrm{~m}$ of the Columbia River, and in undisturbed ground, a survey was required prior to commencement of excavation. The project area was surveyed by P. E. Minthorn on January 10, 1990.

Cultural Resources: Several artifacts were noted adjacent to the project area, principally firecracked rocks and spalled cobbles; however, none was located in concentrations dense enough for the area to be designated a site, and none was in undisturbed settings. Given these findings, an archaeological monitor was required to be present during ground disturbing activities. Excavations for the pond are currently ongoing at the time of this writing. No cultural remains have been uncovered, and all excavations so far have been confined to fill areas. 


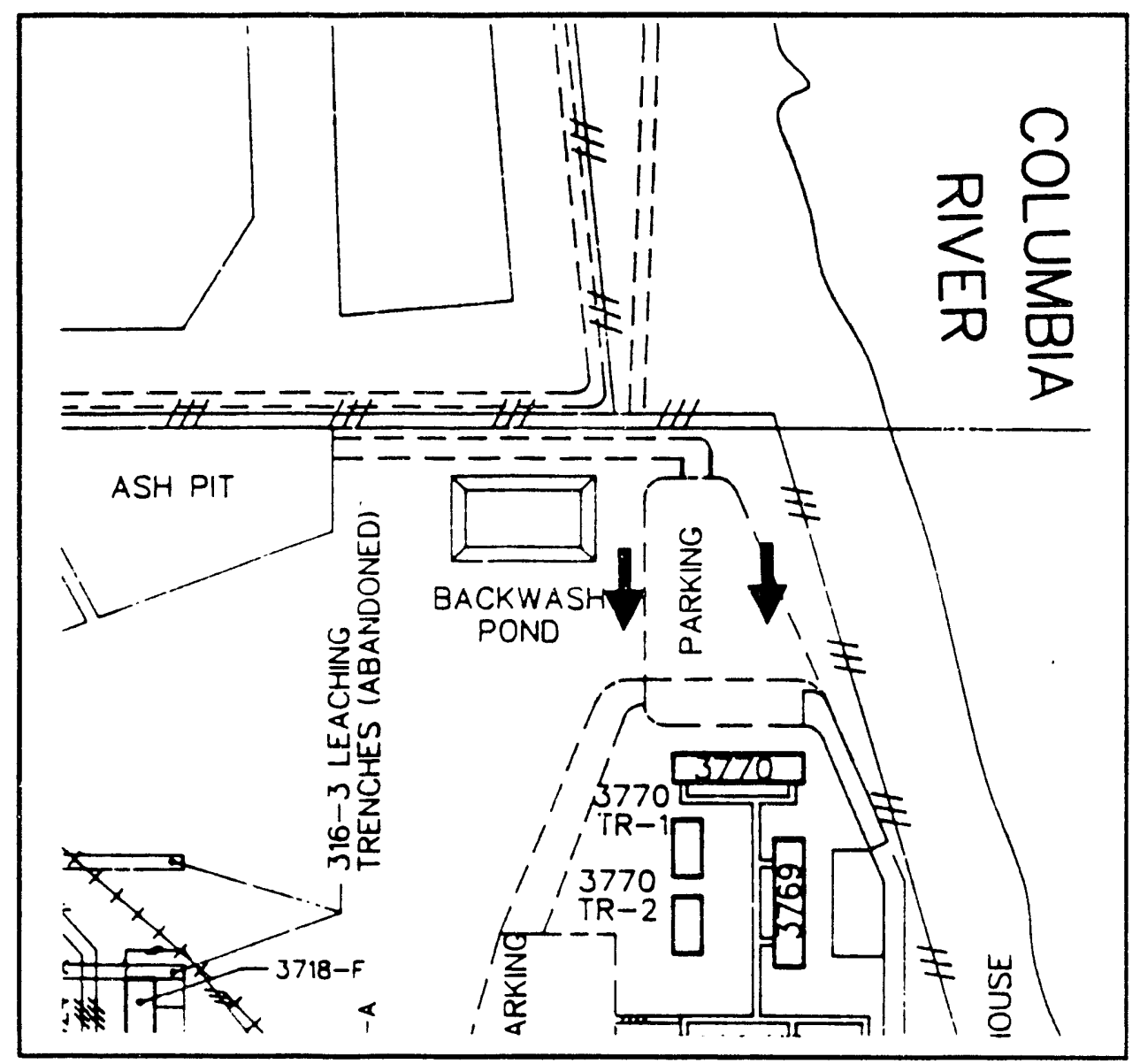

FIGURE A.10. Location of the Area Reviewed for the 300 Area Filter Plant Backwash Pond, HCRC \#89-300-028, on a Portion of a 300 Area General Layout Map (October 1987) 
HCRC \#89-300-029

\section{BUILDING CABLE INSTALLATION}

\section{Requester: L. A. Jeppson} Facilities Projects

Westinghouse Hanford Company

Richland, WA 99352

Project Description: Archaeological monitoring was required during the installation of a cable within the 300 Area because of its proximity to the Columbia River shoreline (Figure A.11). Literature and records did not reveal the presence of any known cultural properties within the project area, and the proposed improvements are all within previously disturbed areas. The cable trench extended from the 3770 Building, along the eastern periphery of the 300 Area, to the south side of the 338 Building. Trench excavations were monitored by P. E. Minthorn on November 9 and $10,1990$.

Cultural Resources: Excavations rarely extended below fill material, reaching a maximum depth of $1 \mathrm{~m}$. No cultural materials were encountered. 


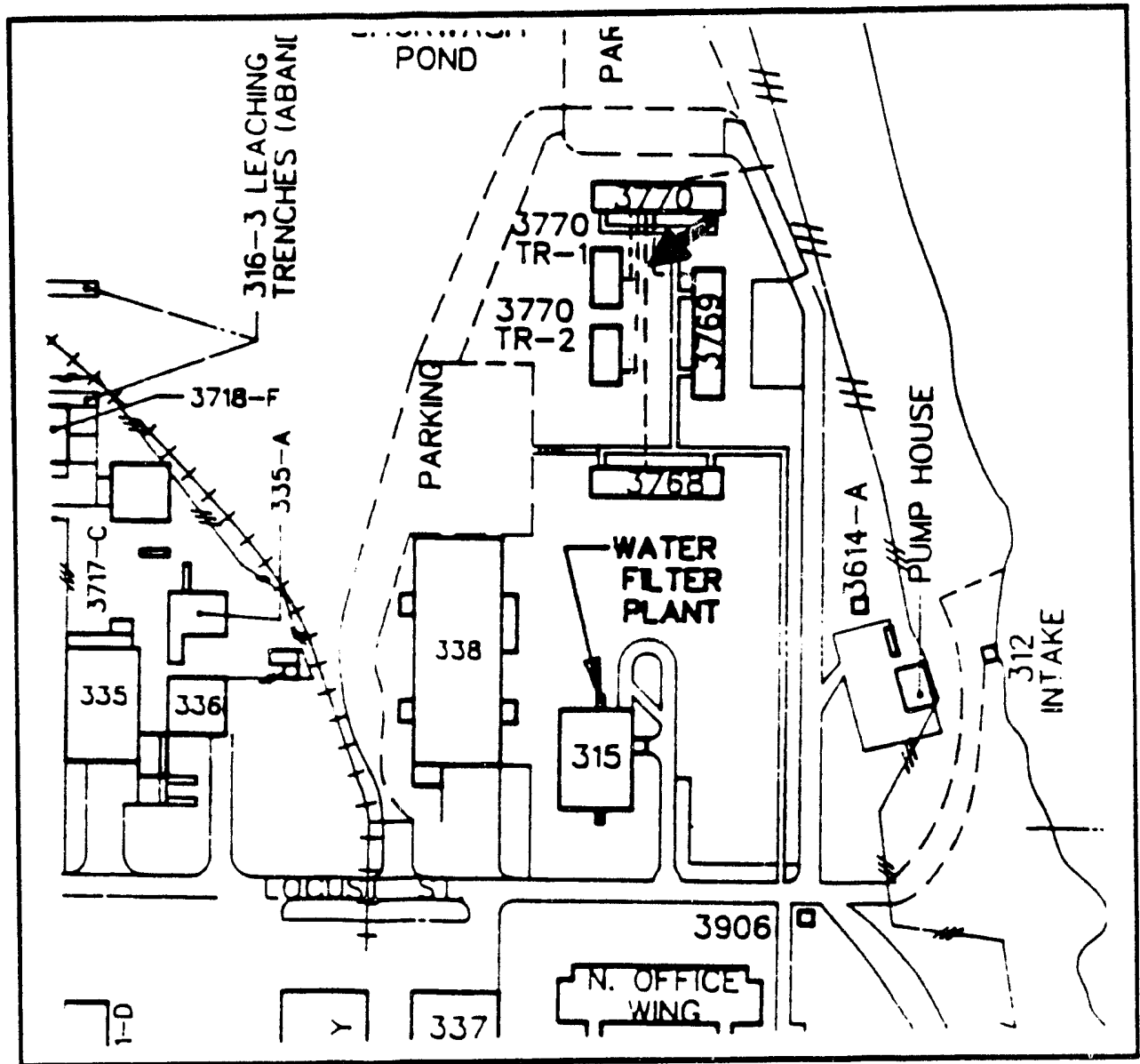

FIGURE A.11. Location of the Area Reviewed for the 3770 Building Cable Installation, HCRC \#89-300-029, on a Portion of a 300 Area General Layout (October 1987) 
HCRC \#89-300-031

3765 TRAILERS $1 \& 2$ INSTALLATION

Requester: V. P. Epperly

Facilities Engineering

Pacific Northwest Laboratory

Richland, WA 99352

Project Description: Two double-wide trailers have been installed $15 \mathrm{~m}$ north of the

3765 Building in an area previously occupied by three single-wide office trailers (Figure A.12).

Limited excavations were required to hook up utilities to the new trailers. Literature and records

did not reveal the presence of any known cultural properties within the project area, and the excavation areas were all within previously disturbed areas. Because of their proximity to the Columbia River, archaeological monitoring of the excavations was required.

Cultural Resources: The project proceeded without this office being notified. It is unknown if any cultural property was impacted by ground disturbing activity. 


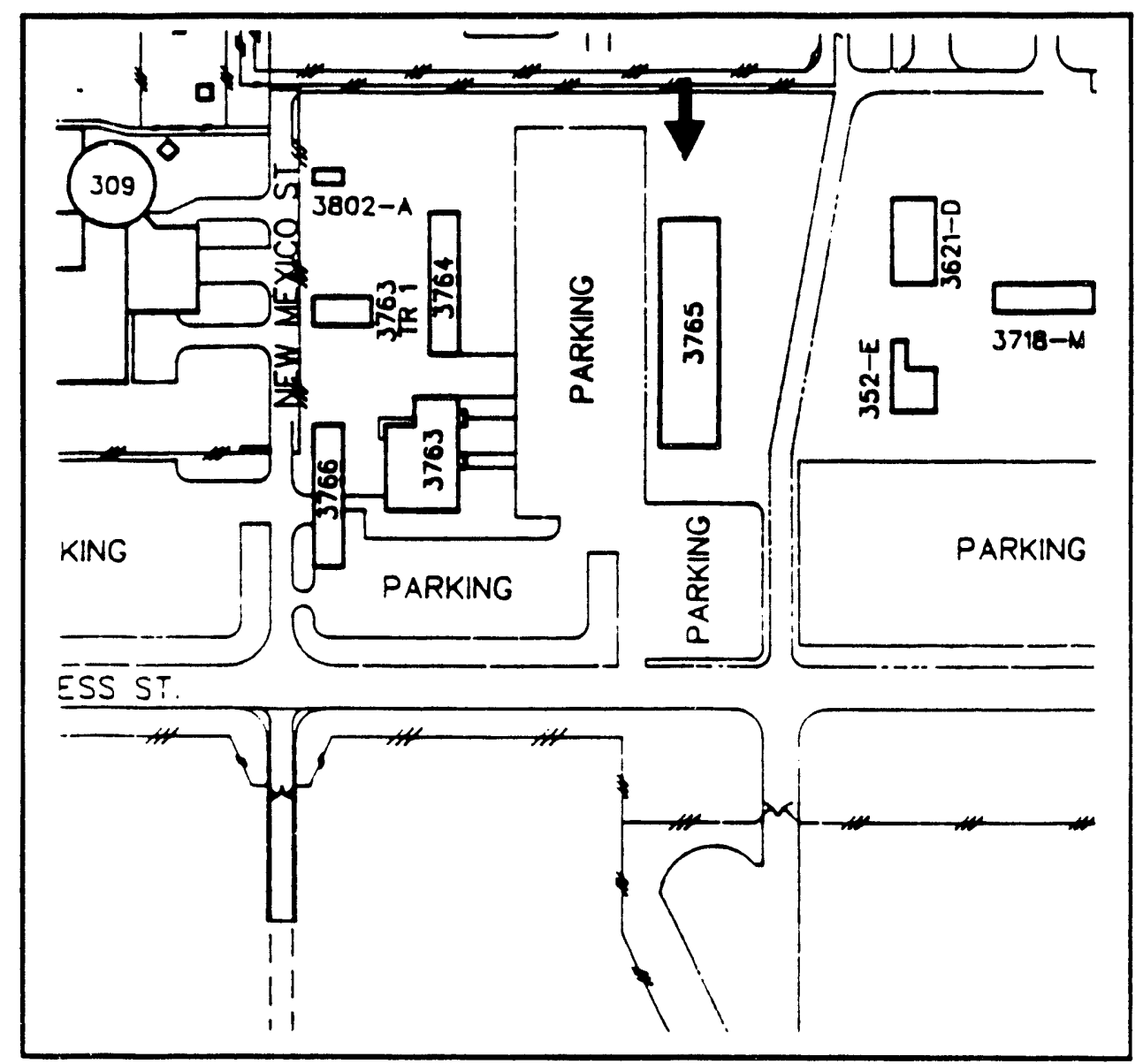

FIGURE A.12. Location of the Area Reviewed for the 3765 Trailers 1 and 2 Installation, HCRC \#89-300-031, on a Portion of a 300 Area General Layout Map (October 1987) 
HCRC \#89-300-032

300 AREA 92L-GFL-047 ELECTRICAL DISTRIBUTION CONVERSION, PHASE II

Requester: P. I. Thakkar

Utilities Projects Processing

and Landlord Projects

Westinghouse Hanford Company

Richland, WA 99352

Broject Description: This project to convert the primary electrical distribution system throughout the northern portion of the 300 Area is currently in the planning stage (Figure A.13). Grounddisturbing aspects of the project will include installation of new underground electrical and signal conductors, pad mounted transformers, manholes, and perimeter lighting. Conduits will measure 0.3 to $1.2 \mathrm{~m}$ in width and 0.6 to $1.2 \mathrm{~m}$ in depth, manholes 1.2 to $1.8 \mathrm{~m}$ deep, light post foundations $1 \mathrm{~m}$ in diameter and 1 to $1.2 \mathrm{~m}$ deep, and transformer foundations will measure $0.5 \mathrm{~m}^{2}$ by $0.3 \mathrm{~m}$ deep. Literature and records did not reveal the presence of any known cultural properties within the project area, and the proposed improvements are all within previously disturbed areas. Some excavations will occur, however, within $\mathbf{4 0 0} \mathrm{m}$ of the Columbia River, and, therefore, monitoring for cultural materials will be required.

Cultural Resources: This project is still awaiting funding. Construction is not expected to begin until 1992. 


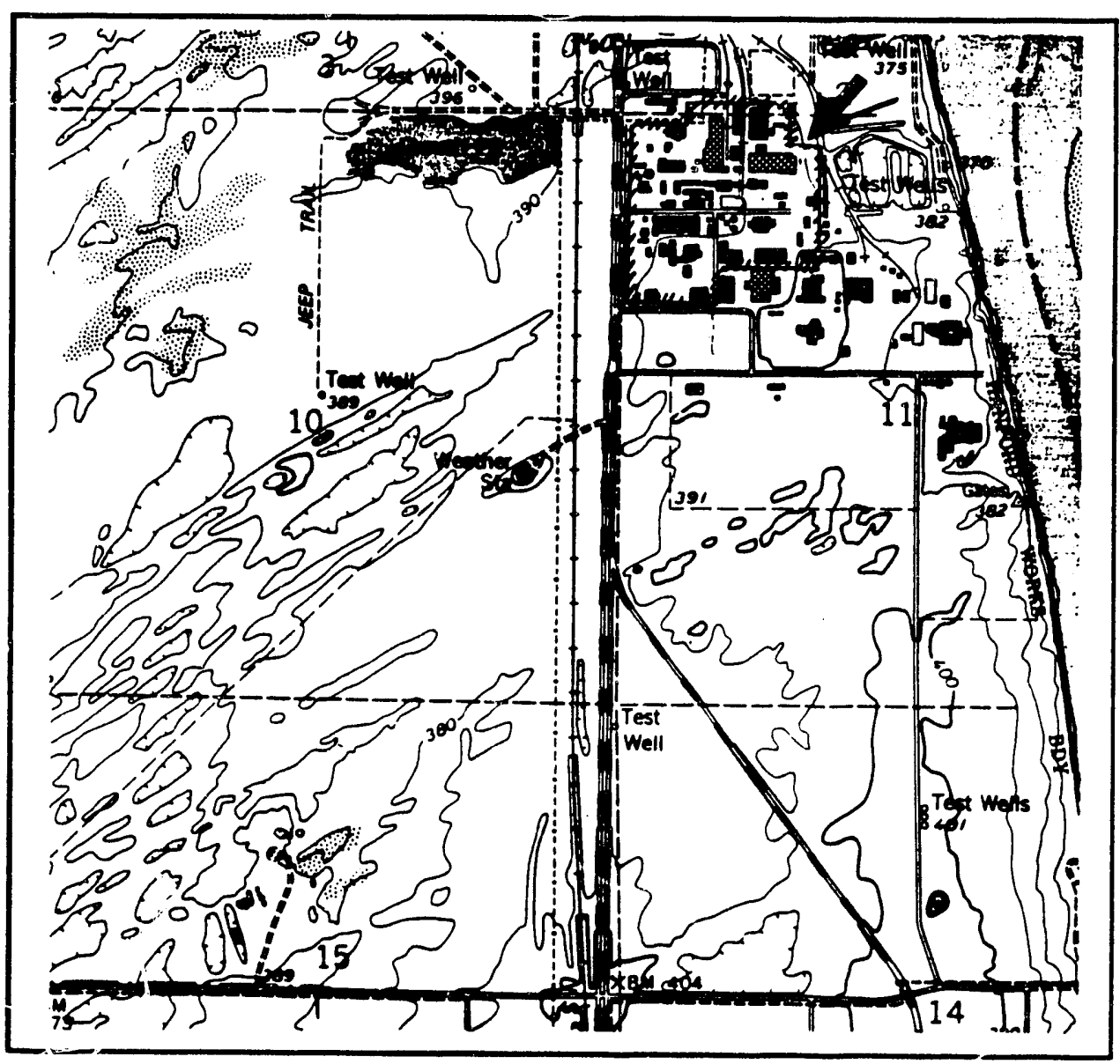

EIGURE A.13. Location of the Area Reviewed (within hatched lines) for the 300 Area 92L-GFL-047 Electrical Distribution Conve-siun, HCRC \#89-300-032, on a Portion of the USGS Richland Quadrangic, Sec. 2 T10N-R28E 
HCRC \#89-600-010

PROJECT L-006 ROUTES 3S AND 4S INTERSECTION SAFETY IMPROVEMENTS

Requester: E. M. Koellermier Projects Department

Westinghouse Hanford Company

Richland, WA 99352

Project Description: This project entailed plans to upgrade and construct both highway Route $4 \mathrm{~S}$ and the Route $3 \mathrm{~S}$ intersection (Figure A.14). The project scope includes

- the reconstruction of Route $4 \mathrm{~S}$ and the Route $3 S$ intersection, including a section tangential to 4 th Street and Route 4 S

- the realignment and reconstruction of the existing curve on Route $4 \mathrm{~S}$

- the reconstruction of a portion of Route 3.

Proposed depth of excavations varied between sections of fill to $1.5 \mathrm{~m}$ below ground surface. A literature and records search failed to reveal the presence of any known cultural properties or archaeological sites. Because a portion of the project was to impact undisturbed ground, however, a pedestrian survey was required. On September 1, 1989, K. A. Hoover and P. E. Minthorn surveyed the project area using standard field methods as outlined in the Hanford Cultural Resources Management Plan (Chatters 1989). The project area was revisited by N. A. Cadoret on January 2, 1990.

Cultural Resources: One archaeological site was located during the survey. Temporarily designated HT-89-032, this historic site consisted of a collapsed stock impoundment and associated debris. Temporally diagnostic artifacts indicated a turn-of-the-century date. It was determined that this site may be eligible for nomination to the National Register of Historic Places as representative evidence of past regional economic development.

To avoid impacts to the site, a 20-m culturally sensitive zone was established around the site, and project personnel were alerted to its presence. Monitoring was also required when construction activities approached the site. Monitoring reports indicate that the sensitivity zone has been successful and that construction has avoided the property. 


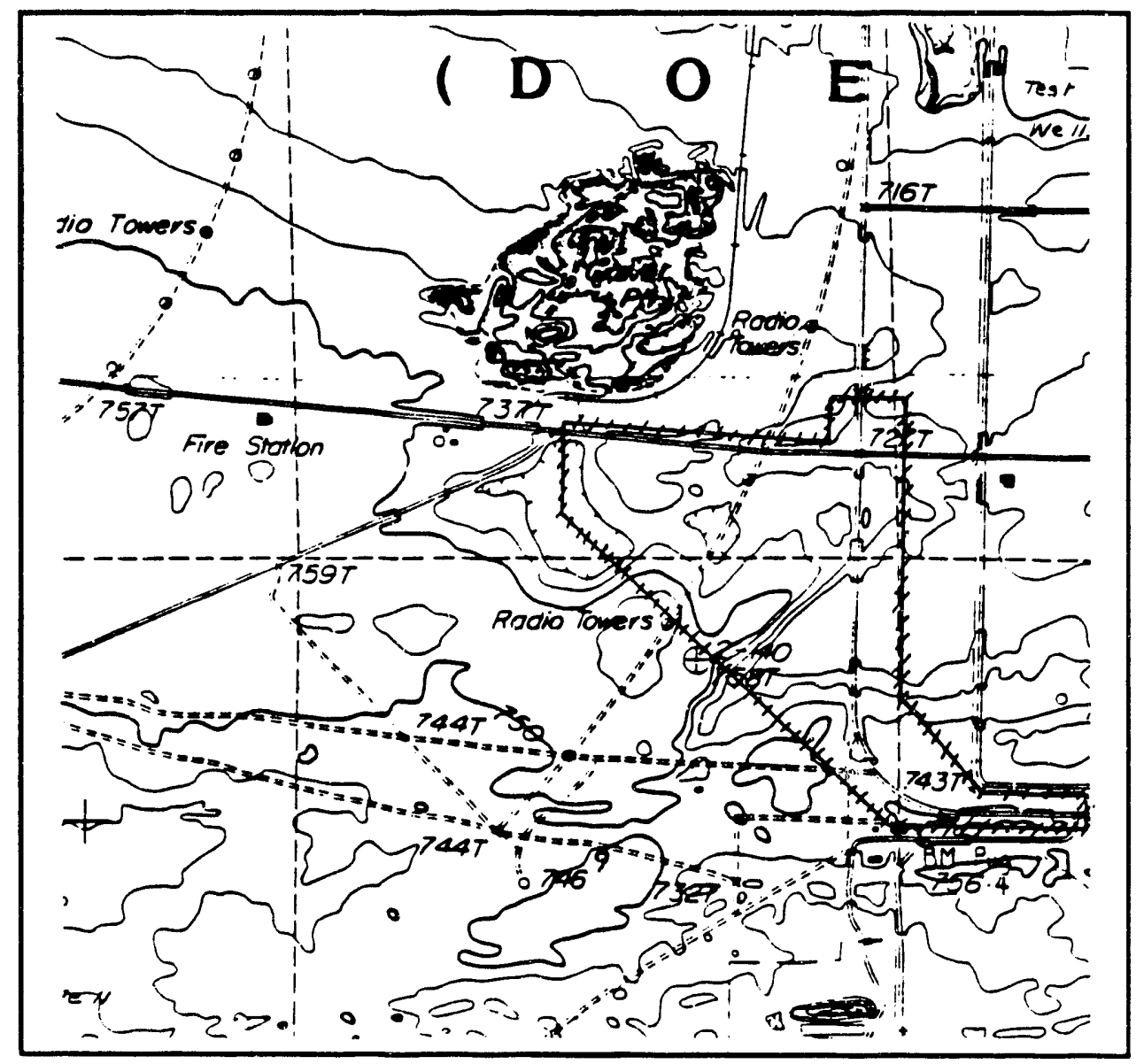

FIGURE A.14. Location of the Area Reviewed (within hatched lines) for the Project L-006 Routes 3S and 4S intersection Safety Improvements, HCRC $\# 89-600-010$, on a Portion of the USGS Gable Butte Quadrangle, Sec. 4 and 9 T12N-R26E 
HCRC \#89-600-011

FRANKLIN CONSERVATION DISTRICT SOIL JUDGING CONTEST

Requester: E. Brincken

USDA Soil Conservation Service

1620 Road $44 \mathrm{~N}$

Pasco, WA 99301

Project Description: As part of a soil judging contest for high-school members of the Future Farmers of America (FFA), the U.S. Soil Conservation Service planned to excavate four soil test pits on DOE land. The pits were located in Franklin county, within Township 13 north, Range 28 east, Section 32 (Figure A.15). The $1.7-\mathrm{m}$ deep, $0.9-\mathrm{m}$ wide by $3.6-\mathrm{m}$-long pits were to be situated in undisturbed ground that is currently leased to the State of Washington Department of Wildlife. Seven potential pit sites were inspected by N. A. Cadoret on September 18, 1989.

Cultural Resources: Of the seven potential locations, two were rejected for use because of the presence of cultural material. Sites B and C on the enclosed map were situated in active sand dunes and contained shell, fire cracked rock, and cryptocrystalline debitage. This archaeological site appeared to date from the Cascade Phase. The remaining locations, A, D, E, F, and G, were cleared of cultural resource concerns. 


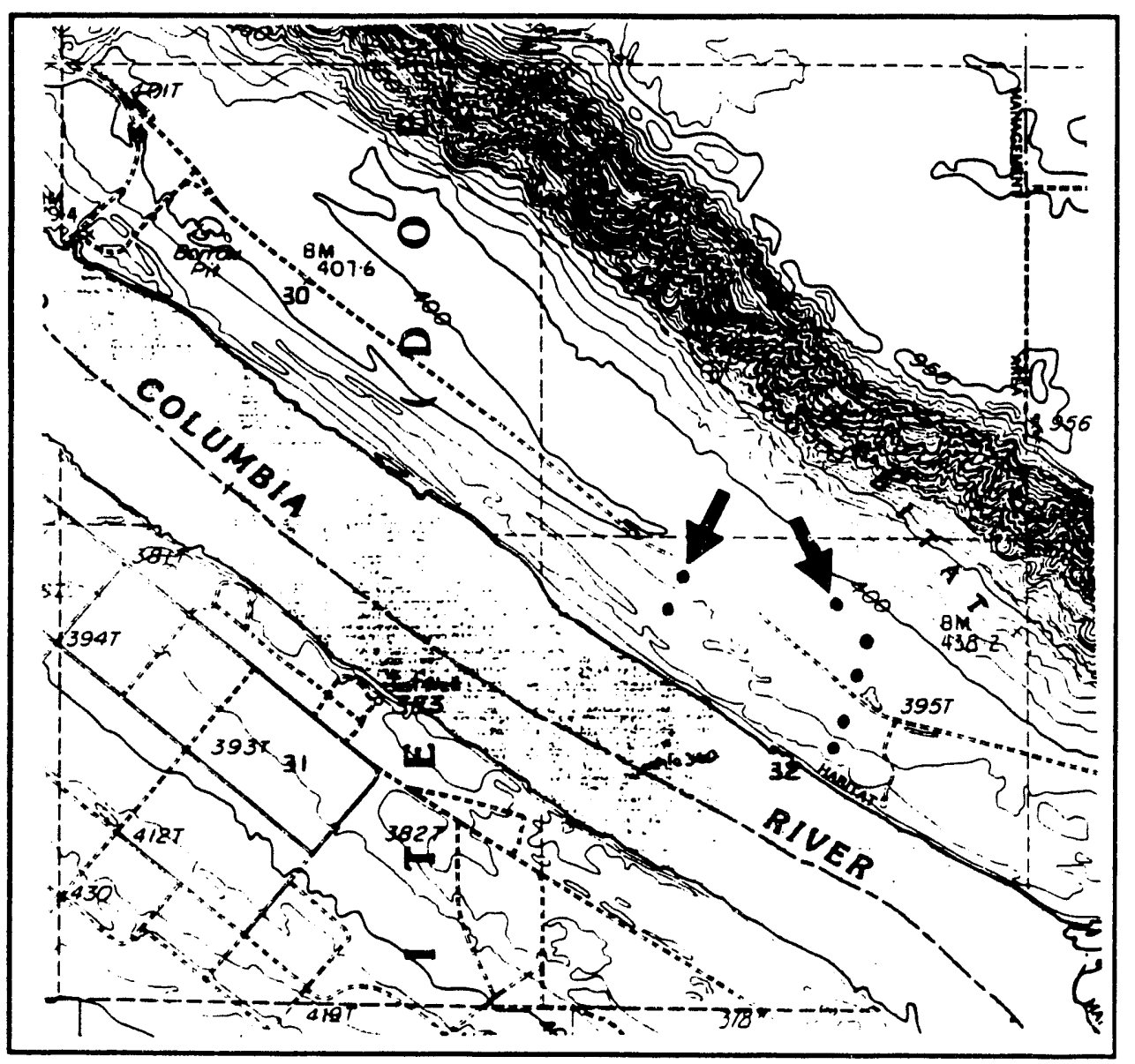

FIGURE A.15. Location of the Area Reviewed for the Franklin Conservation District Soil Judging Contest, HCRC \#89-600-011 on a Portion of the USGS Savage Island Quadrangle, Sec. 30 and 32 T13N-R28E 
HCRC \#89-600-914

DUAL WALL PERCUSSION HAMMER METHOD TEST

Requester: J. Gale

EFSG

Westinghouse Hanford Company

Richland, WA 99352

Project Description: A 23-m by 38-m drilling pad, located adjacent to ARC 3 Road between the 200 East and the 200 West Areas, was to be sited on previously undisturbed ground (Figure A.16). Therefore, a cultural resource survey was required before construction could take place. Aside from leveling activities, which would disturb the ground to a depth of $0.3 \mathrm{~m}$, two test boreholes would each measure $0.3 \mathrm{~m}$ in diameter and reach a depth of $36.5 \mathrm{~m}$. A review of literature and records showed that no archaeological sites or culturally significant properties were known to be located in the project area, but that the area had never been surveyed for cultural properties. On November 16, 1989, P. E. Minthorn surveyed the area using $15-\mathrm{m}$ transect intervals oriented parallel to the road. The entire area inspected measured $80 \mathrm{~m}$ by $75 \mathrm{~m}$.

Cultural Resources: No cultural properties were observed within the undisturbed portion of the project area. 


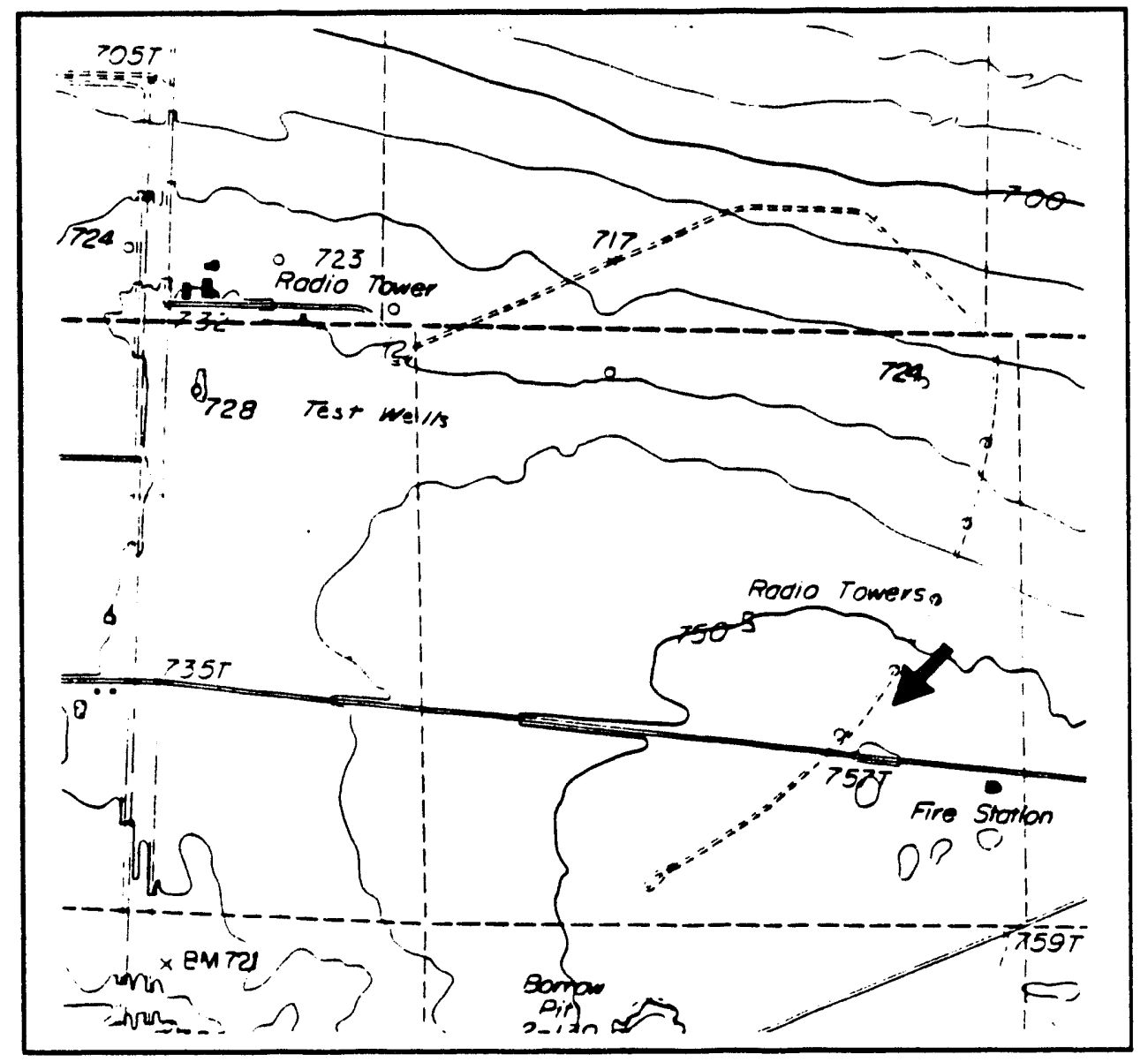

FIGURE A.16. Location of the Area Reviewed for the Dual Wall Percussion Hammer Method Test, HCRC \#89-600-014 on a Portion of the USGS Gable Butte Quadrangle, Sec. 5 T12N-R26E 
HCRC \#89-600-015

United States Geologic Survey Suil Moisture Monitoring Stations

Requester: Ward W. Staubitz

Water Resources Division

United States Geologic Survey

1201 Pacific Avenue

Tacoma, WA 98402

Project Description: As part of an ongoing hydrologic investigation within the Cold and Dry creek watersheds on the Hanford Site, the USGS planned to install five or six soil moisture monitoring stations within these stream channels (Figure A.17). Each monitoring station required installation of three 5-cm neutron probes to a depth of 9 to $12 \mathrm{~m}$. The probes would be installed with a truck-mounted auger rig. A review of literature and records showed that no archaeological sites or culturally significant properties were known to be located in the project area. On December 7, 1989, N. A. Cadoret surveyed the area using 15-m-transect intervals within each impact area.

Cultural Resources: No cultural properties were observed within the project area. 


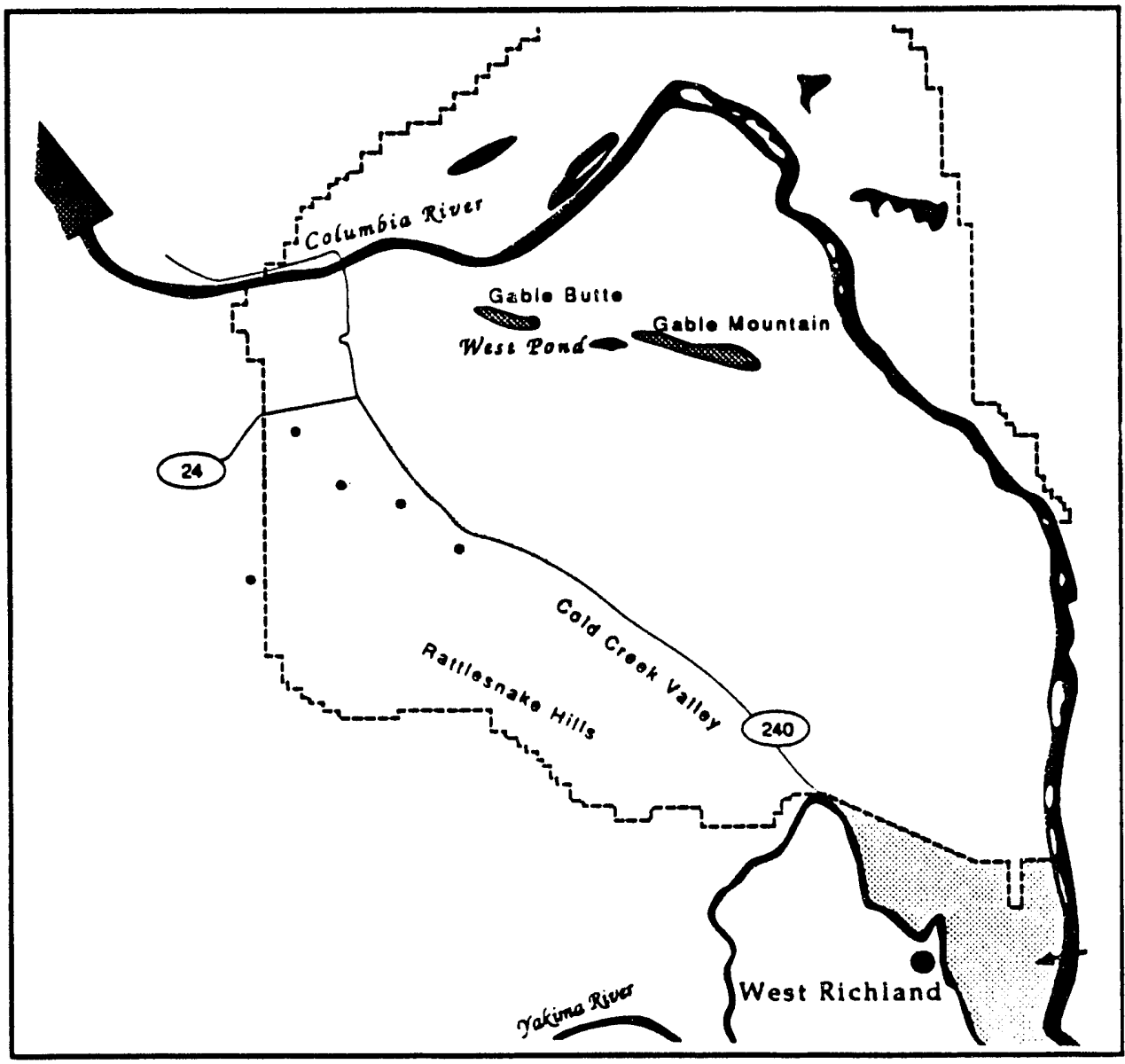

FIGURE A.17. Location of the Area Reviewed for the USGS Soil Moisture Monitoring Stations, HCRC \#89-600-015 on a Portion of a HCRC Site Map (November 1990) 
HCRC \#89-1100-003

EXCESS MATERIALS LAYDOWN YARD

Requester: E. T. Trost

Site Planning Group

Westinghouse Hanford Company

Richland, WA 99352

Project Description: A 6-acre area, located due west of the 1167 Building was the proposed site of an excess material storage yard (Figure A.18). Aside from the installation of protective fencing and lighting, the yard would be graded and graveled. Because this undertaking was to occur on undisturbed ground, a cultural resource survey was required before construction could take place. A review of literature and records showed that no archaeological sites or culturally important properties were known to be located in the project area. On January 2, 1990, a 225-m by $160-\mathrm{m}$ area was inspected by P. E. Minthorn using standard survey techniques.

Cultural Resources: A single historic archaeological site, HT-90-003, was recorded. This consisted of an irrigation canal with two parallel ditches, a cement water chute, wooden water lines, several cement foundations, and associated debris. Due west of the site, ground furrows from abandoned fields are still visible. Preliminary determinations made by the HCRL are that HT-90-003 is not eligible for nomination to the NRHP. However, until the HCRL has consulted with the State Historic Preservation Office, it has been recommended that the requester try to relocate his project in order to avoid impacting the property. The final disposition of this review is as yet unknown. 


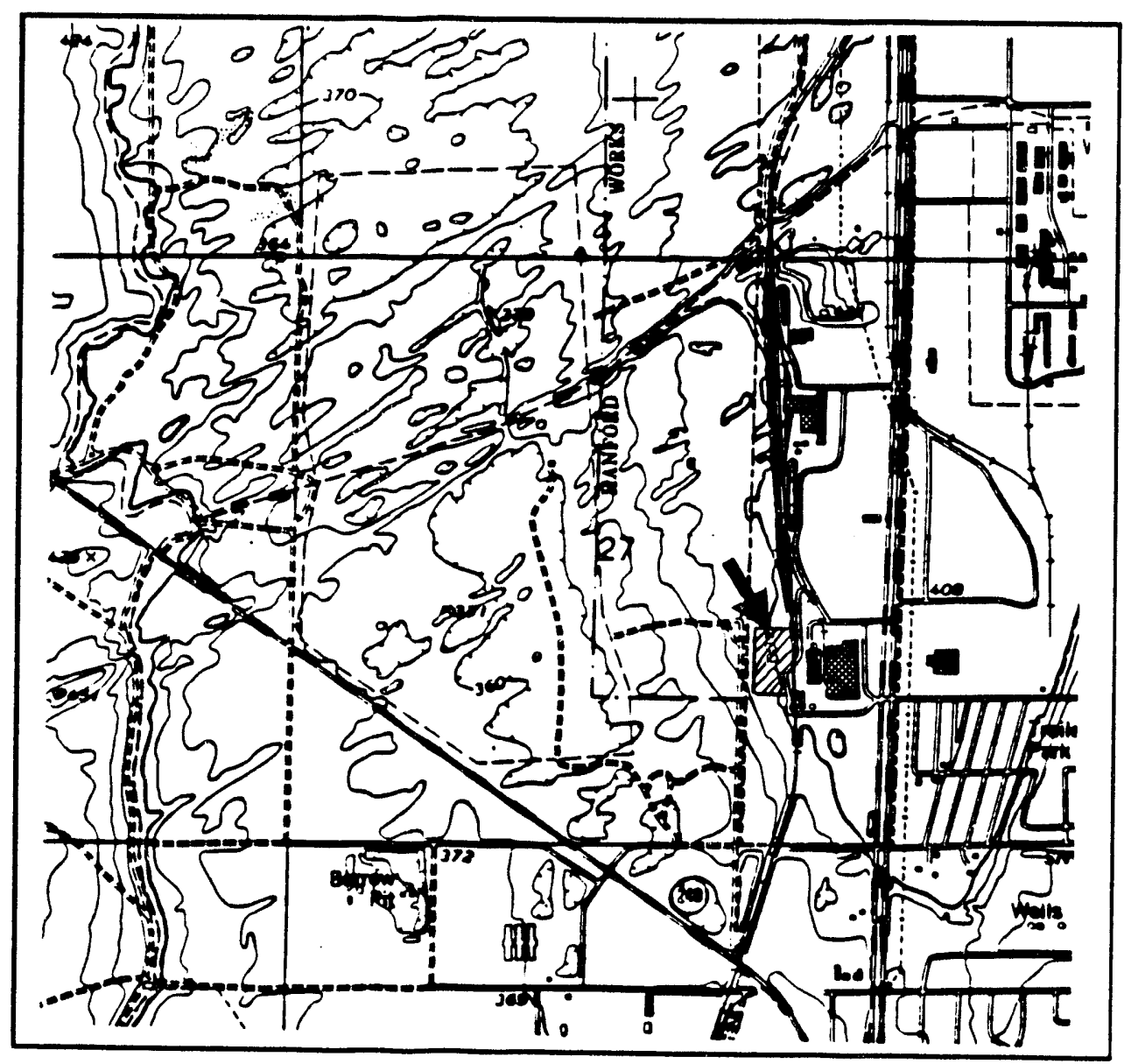

FIGURE A.18. Location of the Area Reviewed for the Excess Materials Laydown Yard, HCRC \#89-1100-003 on a Portion of the USGS Richland Quadrangle, Sec. 27 T10N-R28E 
HCRC \#90-00-001

ENVIRONMENTAL SURVEILLANCE STATIONS

Requester: P. E. Moore

Facilities Management

Pacific Northwest Laboratory

Richland, WA 99352

Project Description: Three environmental monitoring stations were installed during the summer of 1990, off the Hanford Site. These are located at Leslie Groves Park, Richland; Edwin Markham School, Franklin County; and Basin Elementary School, Basin City. Each monitoring station required excavations to a maximum depth of $0.9 \mathrm{~m}$ below grade for the installation of underground electrical and irrigation systems. Literature and recoids did not reveal the presence of any known cultural properties within the project areas. The site at Leslie Groves Park required monitoring for cultural resources because of its proximity to the Columbia River (Figure A.19). A pedestrian survey was not warranted because of the small size of the area to be impacted and its previously disturbed nature. Excavations were monitored throughout July by P. E. Minthorn.

Cultural Resources: No cultural remains were located. 


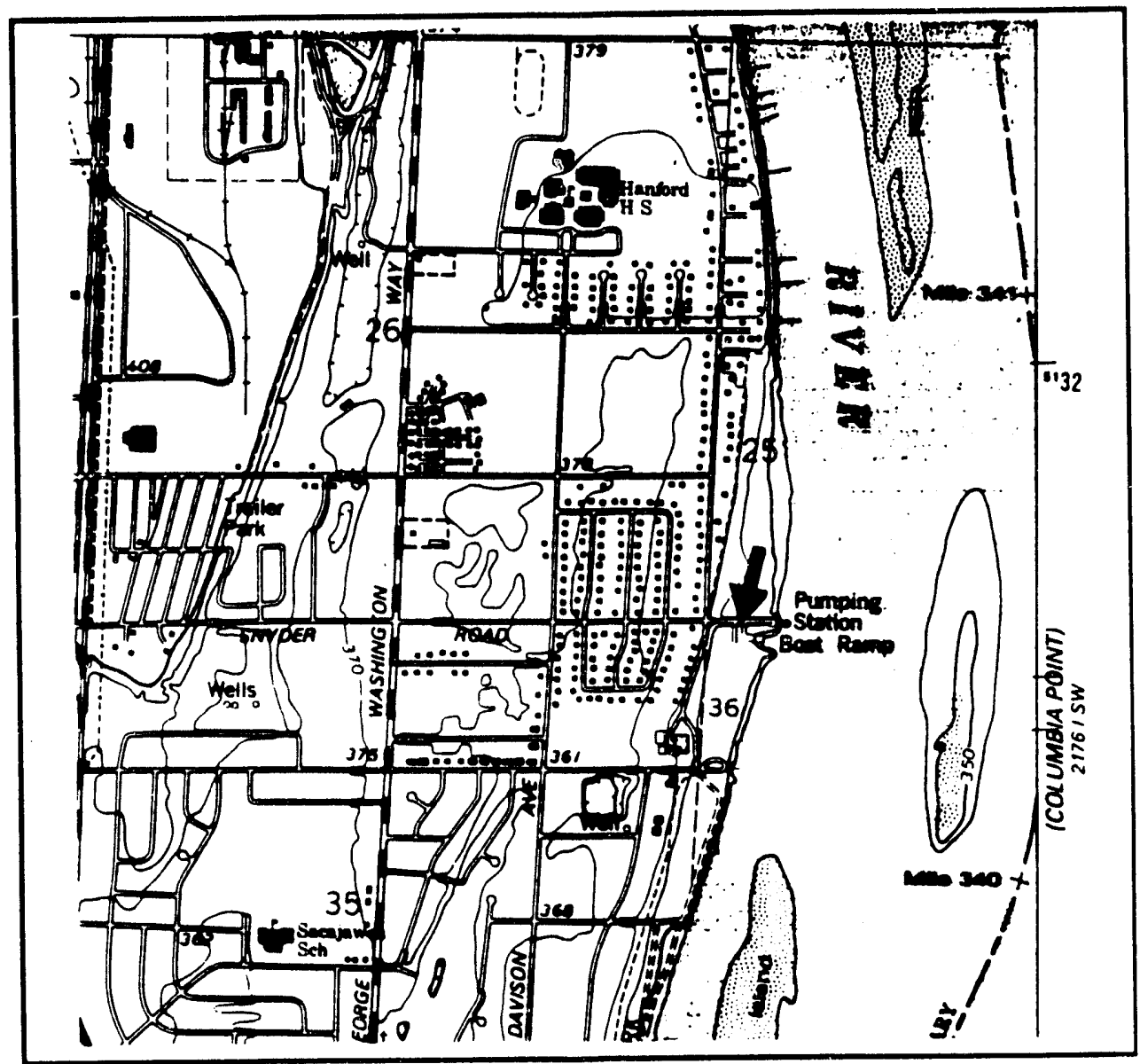

FIGURE A.19. Location of the Area Reviewed for the Environmental Surveillance Stations - Site \#1, HCRC \#90-00-0.01 on a Portion of the USGS Richland Quadrangle, Sec. 36 T10N-R28E 


\section{HCRC \#90-00-002}

\section{PRIEST RAPIDS LAND TRANSFER}

Requester: Mr. Kevin Clark

Site Management Division

U. S. Department of Energy

Field Office, Richland

Richland, WA 99352

Project Description: Two parcels of land currently under the jurisdiction of the U. S. Department of Energy were proposed to be excessed to the Grant County Public Utilities District (PUD)

(Figure A.20). The transfer of title from federal to county ownership is defined as an undertaking under the National Historic Preservation Act (NHPA) and, as such, is subject to a cultural resource review to ensure that eligible cultural properties are not inadvertently transferred. A review of literature and records showed that no archaeological sites or culturally important properties were known to be located in the project area. On June 11, 1990, the two parcels, found in Section 2, Township 13 north, Range 23 east, were inspected by P. E. Minthorn using standard survey techniques as outlined in the Hanford Cultural Resources Management Plan.

Cultural Resources: In the NW $1 / 4$ of the SW 1/4 of Section 2, which is immediately adjacent to and on the west side of Priest Rapids Dam, two historic features were recorded. One feature was a cement foundation of relatively recent origin, with associated neoteric debris, clearly ineligible for nomination to the National Register of Historic Places (NRHP). The other feature consists of a rectangular depression measuring $10 \mathrm{~m}$ by $30 \mathrm{~m}$ with an average depth of $15 \mathrm{~cm}$ below grade. This area was identified by Rex Buck, of the Wanapum, as the location of the first post-dam ceremonial longhouse of his people. Longhouse sites, even when no longer in use, symbolize the continuity of traditional tribal lifeways; this site is the approximate equivalent of an abandoned, but never desanctified, church within the Euro-American culture. Given this interpretation, this feature is not eligible for nomination to the NRHP under 36CFR800. However, it may be protected under the American Indian Religious Freedom Act. Considering the fact that the land will be released to the Grant County PUD and will in all probability be designated for the use of the Wanapum, it does not appear that the land transfer will have an affect on the religious freedom of the Wanapum.

The second parcel, situated in the SE $1 / 4$ of the SW $1 / 4$ of Section 2, contained no cultural resources, a situation attributable to the development of a borrow pit, which was used for the construction of a nearby levy. 


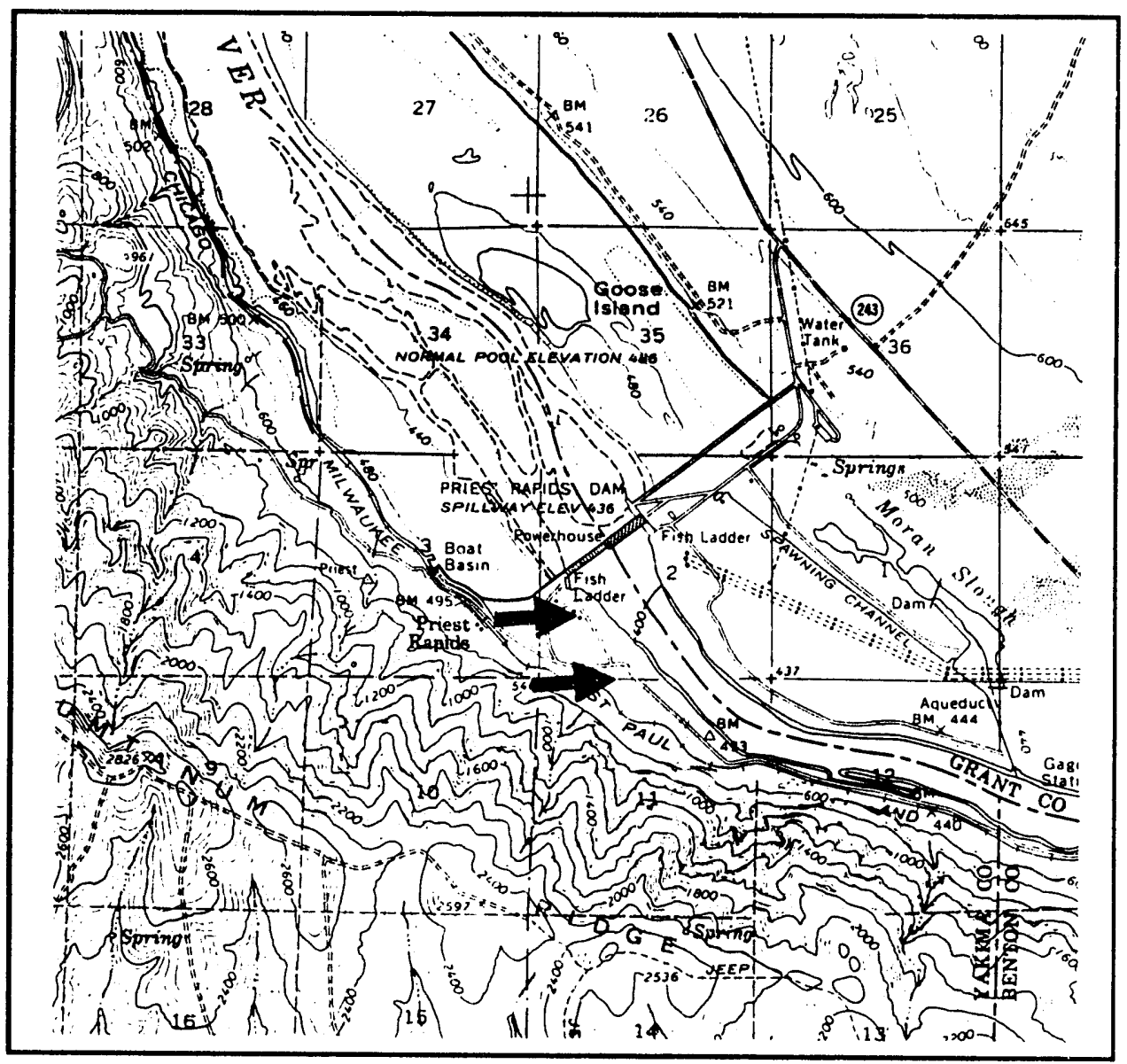

FIGURE A.20. Location of the Area Reviewed for the Priest Rapids Land Transfer, HCRC \#90-00-002 on a Portion of the USGS Priest Rapids Quadrangle 1965, Sec. 2 T13N-R23E 
HCRC \#90-200-010

SOIL COLUMN DISPOSAL SITE EVALUATION; LOCATION 1.

Requester: K. J. Koegler

Environmental Engineering Group

Environmental Division

Westinghouse Hanford Company

Richland, WA 99352

Projact Description: As part of the site evaluation phase, three areas were under consideration for the potential location of a new soil column disposal site (Figure A.21). Two of the proposed areas, numbers 2 and 3, had been previously surveyed, thereby making further evaluation unnecessary. Area number 1, a 2787- $\mathrm{m}^{2}$ area located north of the 200 West Area, had never been surveyed for archaeological properties and was situated on largely undisturbed ground. Therefore, field survey was required. A review of literature and records showed that no archaeological sites or culturally important properties were known to be located in the project area. On June 15, 1990, the area was inspected by P. E. Minthorn using standard survey techniques as outlined in the Hanford Cultural Resources Management Plan.

CulturaL Resources: No cultural resources were located. 


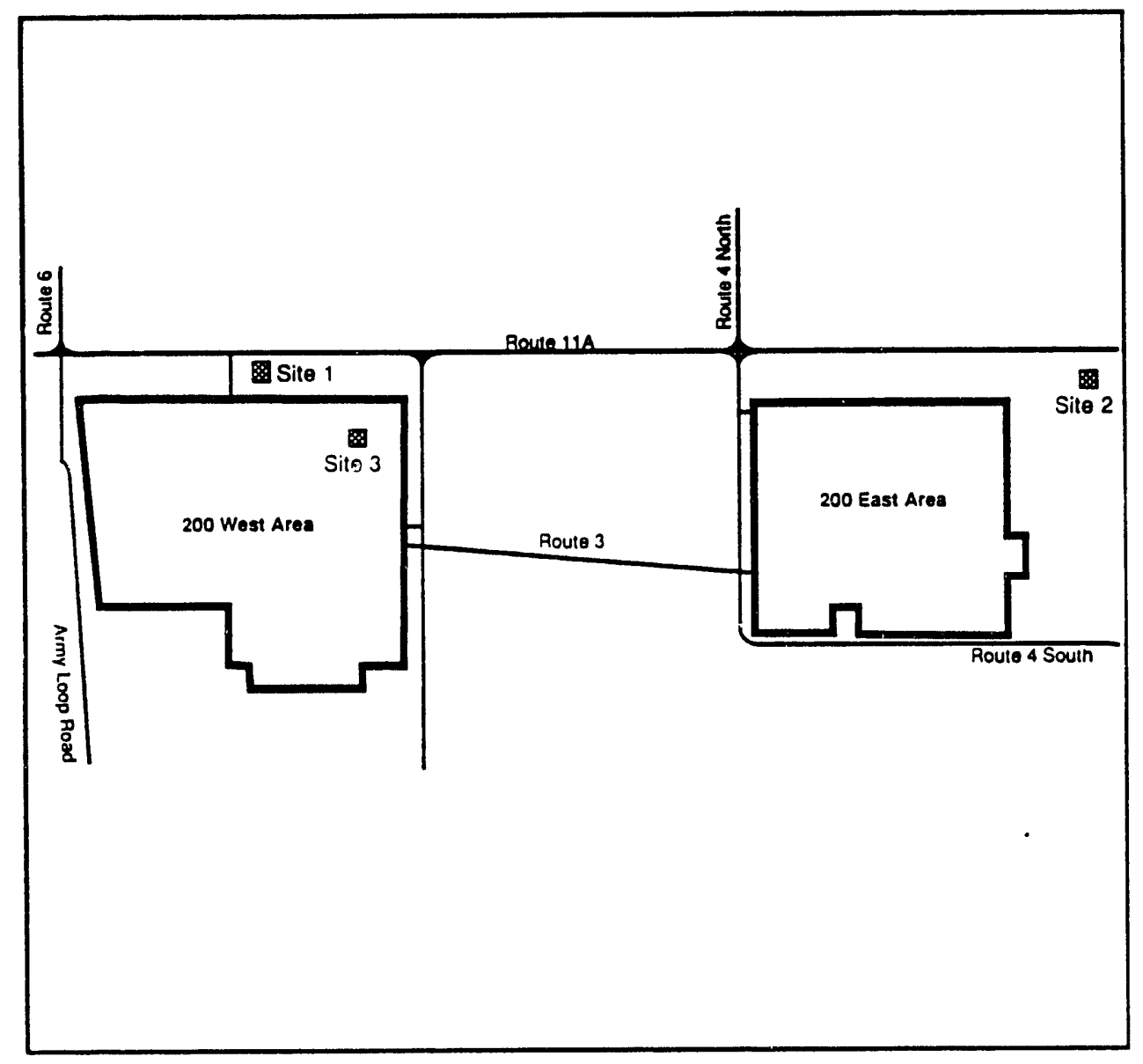

FIGURE A.21. Location of the Area Reviewed for the Soil Column Disposal Site, HCRC \#90-200-010 on a Portion of a Westinghouse Hanford Company

Project Map 
HCRC \#90-300-001

\section{TRAILER AND 337 BUILDING CONDUIT INSTALLATION}

\section{Requester: L. A. Jeppson}

Facilities Projects

Westinghouse Hanford Company

Richland, WA 99352

Project Description: As part of a utilities upgrade, two conduit installation trenches were required within the 300 Area, one, $19 \mathrm{~m}$ long, south of the 318 Trailer and the other, $76 \mathrm{~m} \mathrm{long}$, southeast of the 337 Building (Figure A.22). Although the excavations were to take place in previously disturbed ground, the trench adjacent to the 337 Building fell within the Columbia River sensitivity zone, and, therefore, monitoring by ar archaeologist was required during grounddisturbing activities. Literature and records did not reveal the presence of any known cultural properties within the project area. N. A. Cadoret monitored excavations on January 9 and 12, 1990.

Cultural Resources: Excavations rarely extended below fill material, reaching a maximum depth of $0.9 \mathrm{~m}$. No cultural materials were encountered. 


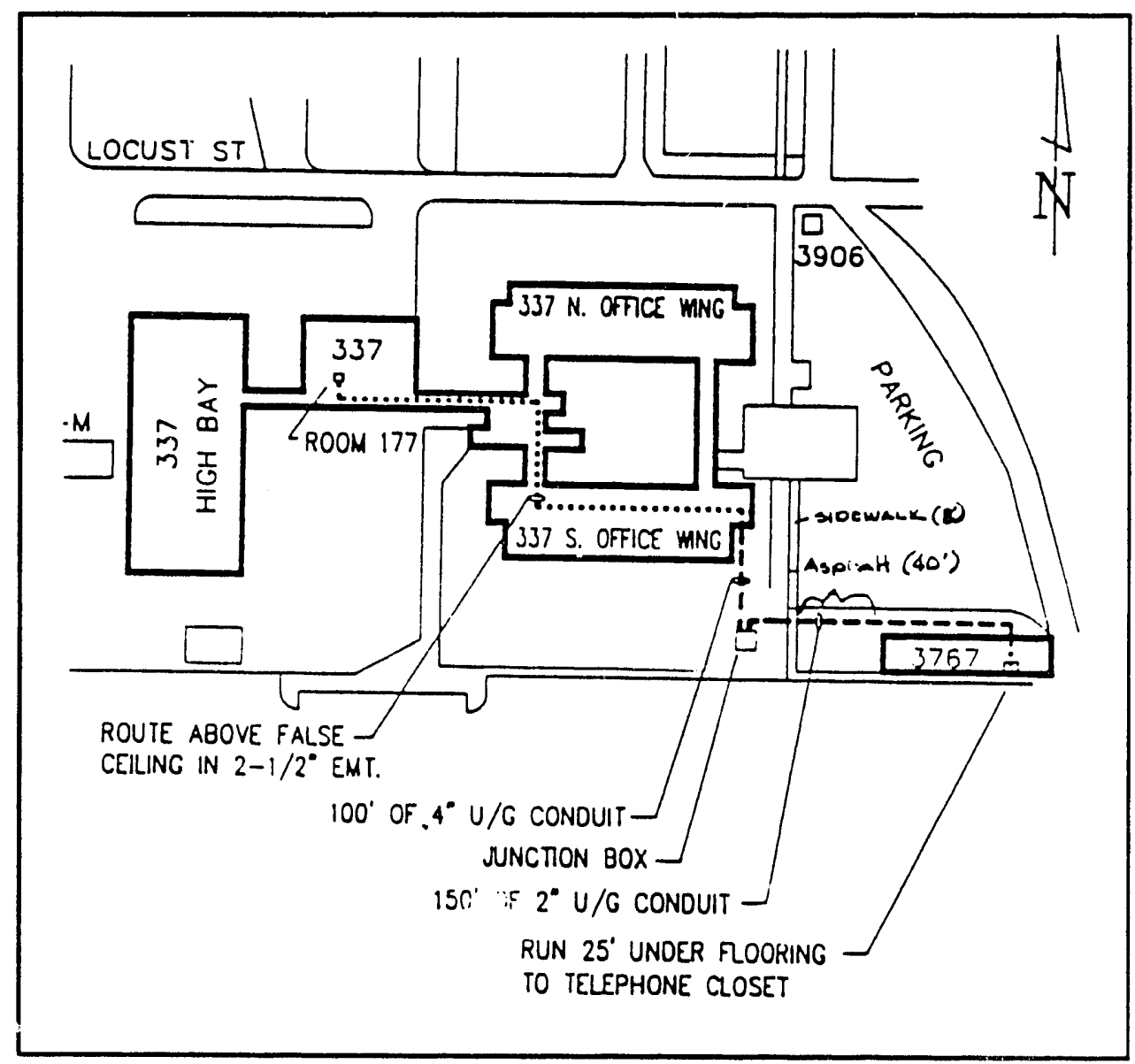

FIGURE A.22. Location of the Area Reviewed for the 318 Trailer and 337 Building Conduit, HCRC \#90-300-001 on a Portion of a Westinghouse Hanford Company Site Sketch Map 
HCRC \#90-300-005

\section{AREA ACCESS GATES}

Requester: R. R. Knight

Site Services

Westinghouse Hanford Company

Richland, WA 99352

Project Description: Six access restriction gates were erected across gravel roads within the northern portion of the 300 area (Figure A.23). Each gate required excavation of two $1-\mathrm{m}^{2}$ by 2-m-deep post holes, with the majority of these placed in previously disturbed ground. Literature and records did not reveal the presence of any known cultural properties within the project area. A pedestrian survey was not warranted because of the small size of the areas to be impacted and their previously disturbed nature. Excavations were monitored February ?, 1990 by P. E. Minthorn.

Cultyral Resources: No cultural remains were observed. 


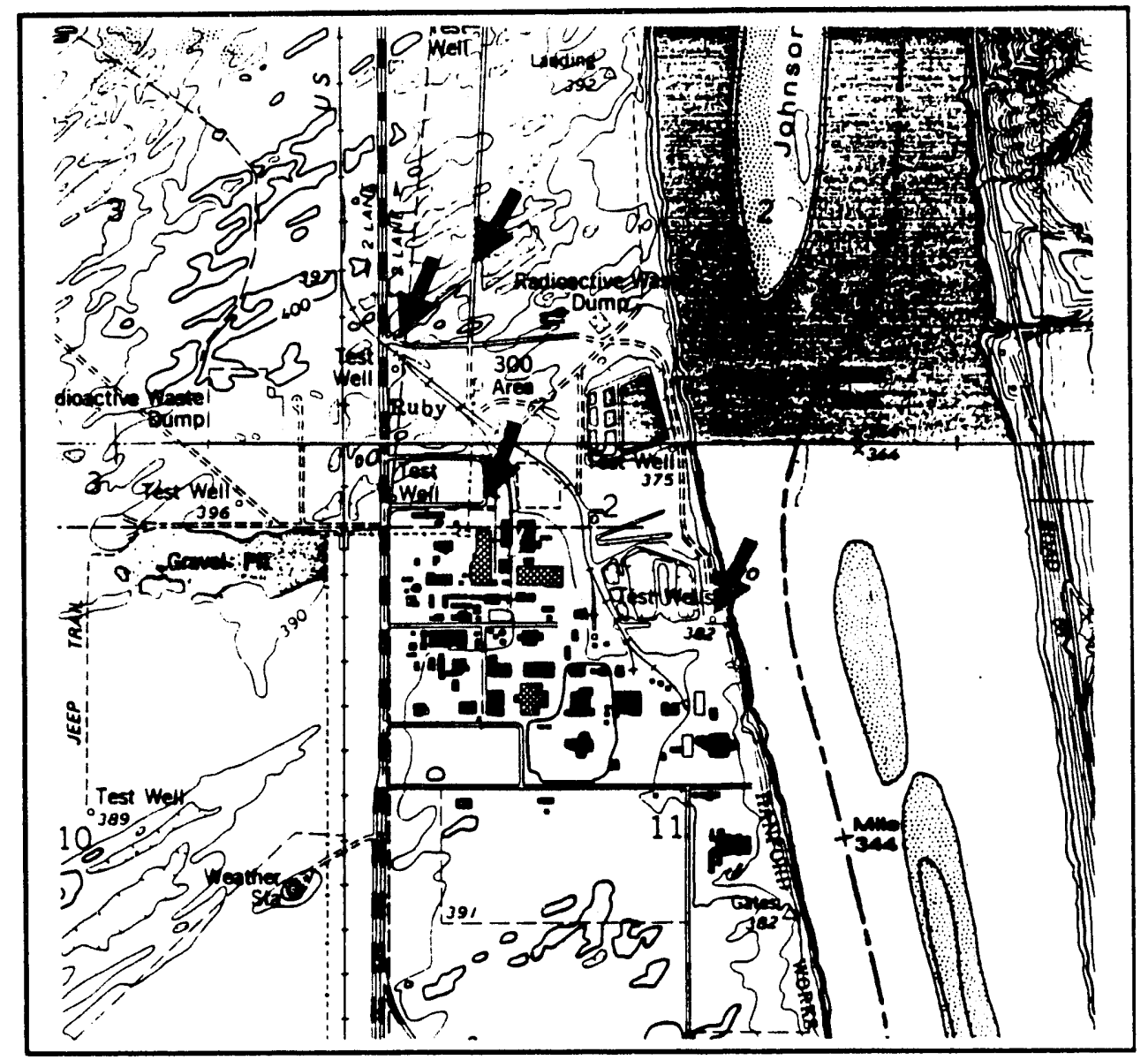

FIGIJRE A,23. Location of the Area Reviewed for the 300 Area Access Gates, HCRC \#90-300-005 on a Portion of the USGS Wooded Island and Richland Quadrangles, Sec. 2 T10N-R28E 
HCRC \#90-300-017

SOUTH ADMINISTRATIVE SUPPORT COMPLEX

Requester: E. T. Trost

Operations Support Services

Westinghouse Hanford Company

Richland, WA 99352

Project Description: This project involves the location of the proposed Administrative Support Complex to be erected directly south of the 300 Area, west of the George Washington Way entrance (Figure A.24). Construction of the new facility will impact 9.3 ha, with excavations for footings and utilities measuring between 1.2 and $3 \mathrm{~m}^{2}$.

A review of our records and applicable literature showed that two historic properties, the Fruitvale School and the Horn Rapids irrigation ditch are located within the project boundaries. An interview conducted with Mrs. Irene Town, a former Fruitvale resident, revealed that the school was also used as a grange hall and community meeting place until it was torn down and rebuilt two miles farther south where Battelle Boulevard enters Stevens Drive. Mrs. Town also stated that many of the buildings in Fruitvale lacked permanent foundations. The original school was built in 1910 (Parker 1979). The Horn Rapids irrigation ditch was constructed by the Lower Yakima Irrigation Company between 1905 and 1908 (Chatters 1989).

P. E. Minthorn surveyed the area on August 17, 1990, using standard survey methods.

Cultural Resources: No visible structural remains of either the Fruitvale School or the Horn Rapids irrigation ditch were located. The lack of foundations used in constructing the school may account for the lack of surface indications, while surface grading or other ground disturbing activities could have removed traces of both historic features.

Because the Fruitvale School no longer possesses integrity in location, design, materials, or workmanship, and is no longer "... likely to yield information important in prehistory or history" (36 CFR 60.4), it is ineligibie for nomination to the National Register of Historic Places. Lack of structural integrity, accompanied by the prevalence of similar features throughout Eastern Washington make the recorded location of the Horn Rapids irrigation ditch also ineligible for nomination to the National Register of Historic Places.

The HCRL recommended that the project proceed in the identified location. 


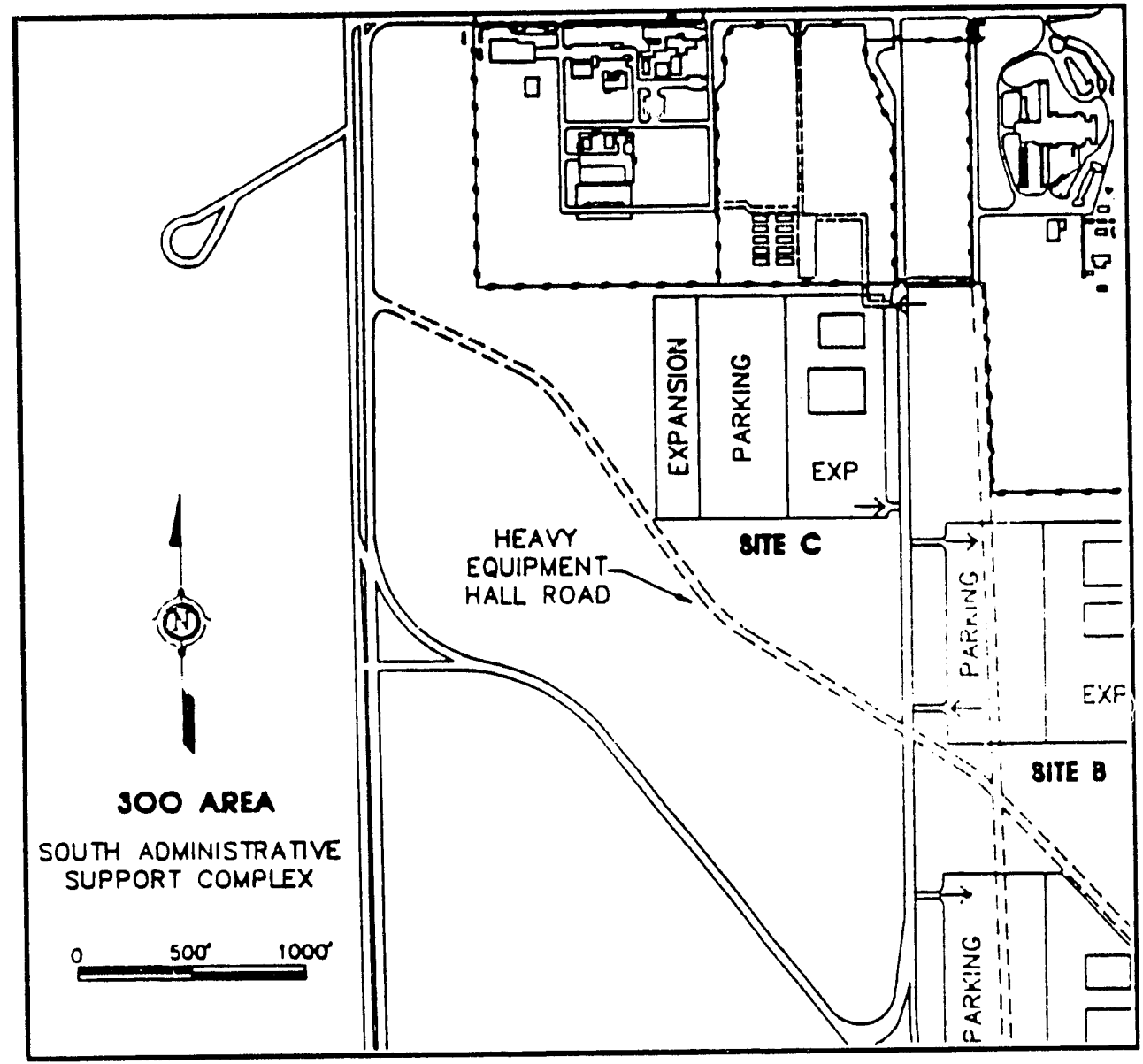

FIGURE A.24. Location of the Area Reviewed for the South Administrative Support Complex (Site C), HCRC \#90-300-017 on a Portion of a Westinghouse Hanford Company's Site Map 
HCRC \#90-400-001

\section{GTE SERVICE INSTALLATION TO WPPSS}

Requester: Mr. Fred Buck

Information Resource Management

Westinghouse Hanford Company

Richland, WA 99352

Project Description: To upgrade communication services to the Washington Public Power Supply System, two new conduits were installed from an existing splice box to the ERDS building located due south of the Fast Flux Test Facility (Figure A.25). The dimensions of the excavation for the trenches measured $116 \mathrm{~m}$ long and $0.5 \mathrm{~m}$ deep. Each trench was a minimum of $0.6 \mathrm{~m}$ wide. Since these trenches crossed undisturbed ground, a pedestrian survey was required before beginning. A review of literature and records showed that no archaeological sites or culturally important properties were known to be located in the project area. On May 10, 1990, the installation corridor was inspected by P. E. Minthorn using standard survey techniques as outlined in the Hanford Cultural Resources Management Plan.

Cultural Resources: No cultural resources were located. 


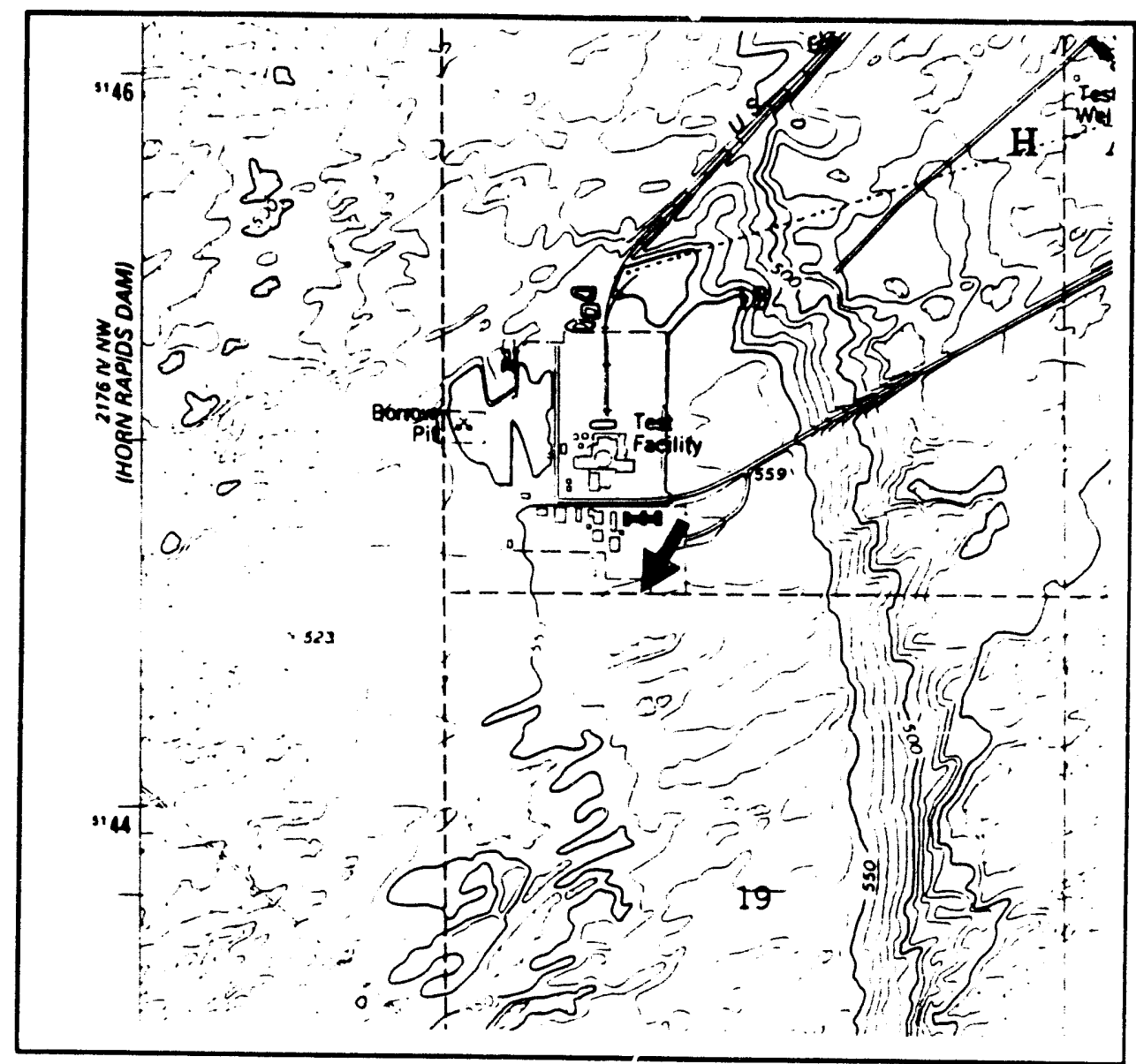

FIGURE A.25. Location of the Area Re'riewed for the GTE Service Installation to WPSS, HCRC \#90-<00-001 on a Portion of the USGS Wooded Island Quadrangle, Sec. 18 T11N-R28E 
HCRC \#90-600-001

\section{G/R COMPLEX, MOBILE OFFICE INSTALLATION}

Requester: R. L. Ingram

Facilities Management

Operations Support Services

Westinghouse Hanford Company

Richland, WA 99352

Project Descrintion: Two doublewide mobile offices, to be installed within and to the north of the $622 \mathrm{G} / \mathrm{R}$ complex, were sited on previously undisturbed land (Figure A.26). Therefore, a

pedestrian survey of the project location was required. The area of potential effect measured $30.4 \mathrm{~m}^{2}$ and $0.9 \mathrm{~m}$ deep. A review of literature and records showed that no archaeological sites or culturally important properties were known to be located in the project area. On February 7 , 1990 , P. E. Minthorn surveyed the area using techniques outlined in the Hanford Cultural Resources Management Plan.

Cultural Resources: No cultural resources were located. 


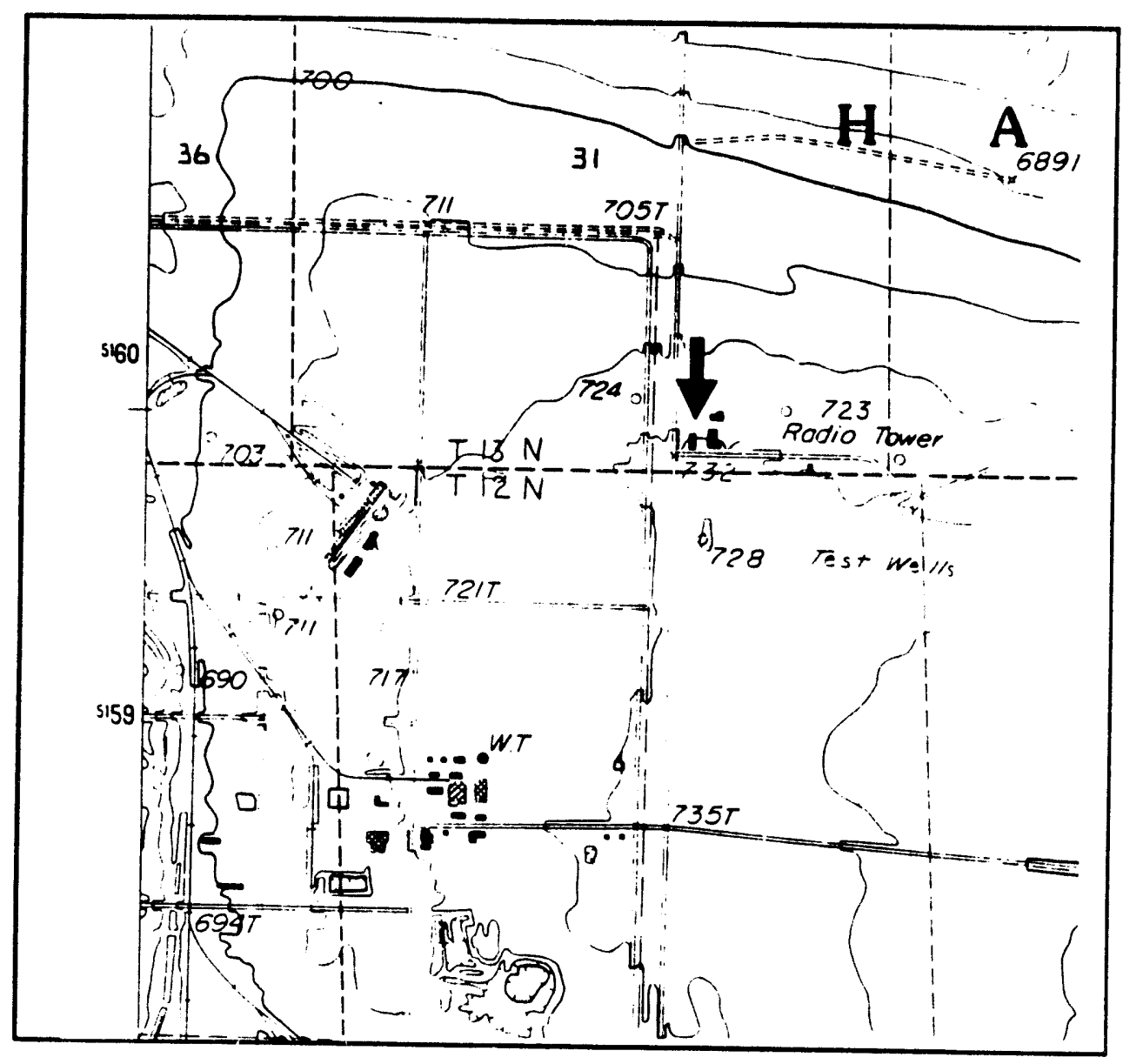

FIGURE A.26. Location of the Area Reviewed for the $622 \mathrm{G} / \mathrm{R}$ Complex, Mobile Office Installation, HCRC \#90-600-001 on a Portion of the USGS Gable Butte Quadrangle, Sec. 31 T13N-R28E 
HCRC \#90-600-002

\section{0-BP-1 GROUNDWATER MONITORING WELLS}

Requester: B. L. Gilkeson

Environmental Projects

Defense Waste Management

Westinghouse Hanford Company

Richland, WA 99352

Project Description: This project entailed plans to install nine groundwater monitoring wells, within and to the north of the 200 East Area, as part of the Environmental Restoration Project (Figure A.27). The project dimensions for each well head included $1.8 \mathrm{~m}^{2}$ of direct disturbance with an additional $30.4 \mathrm{~m}^{2}$ to be cleared and graded around the well head. The depth of excavation varied between 45.7 and $100 \mathrm{~m}$ in the direct impact area, and less than $0.3 \mathrm{~m}$ in the cleared area. A review of literature and records showed that no archaeological sites or culturally important properties were known to be located in the project area. On March 1, 1990, the areas were inspected by P. E. Minthorn using $10-\mathrm{m}$ spaced transects within a $40-\mathrm{m}^{2}$ area at each well site.

Cultural Resources: No cultural resources were located. 


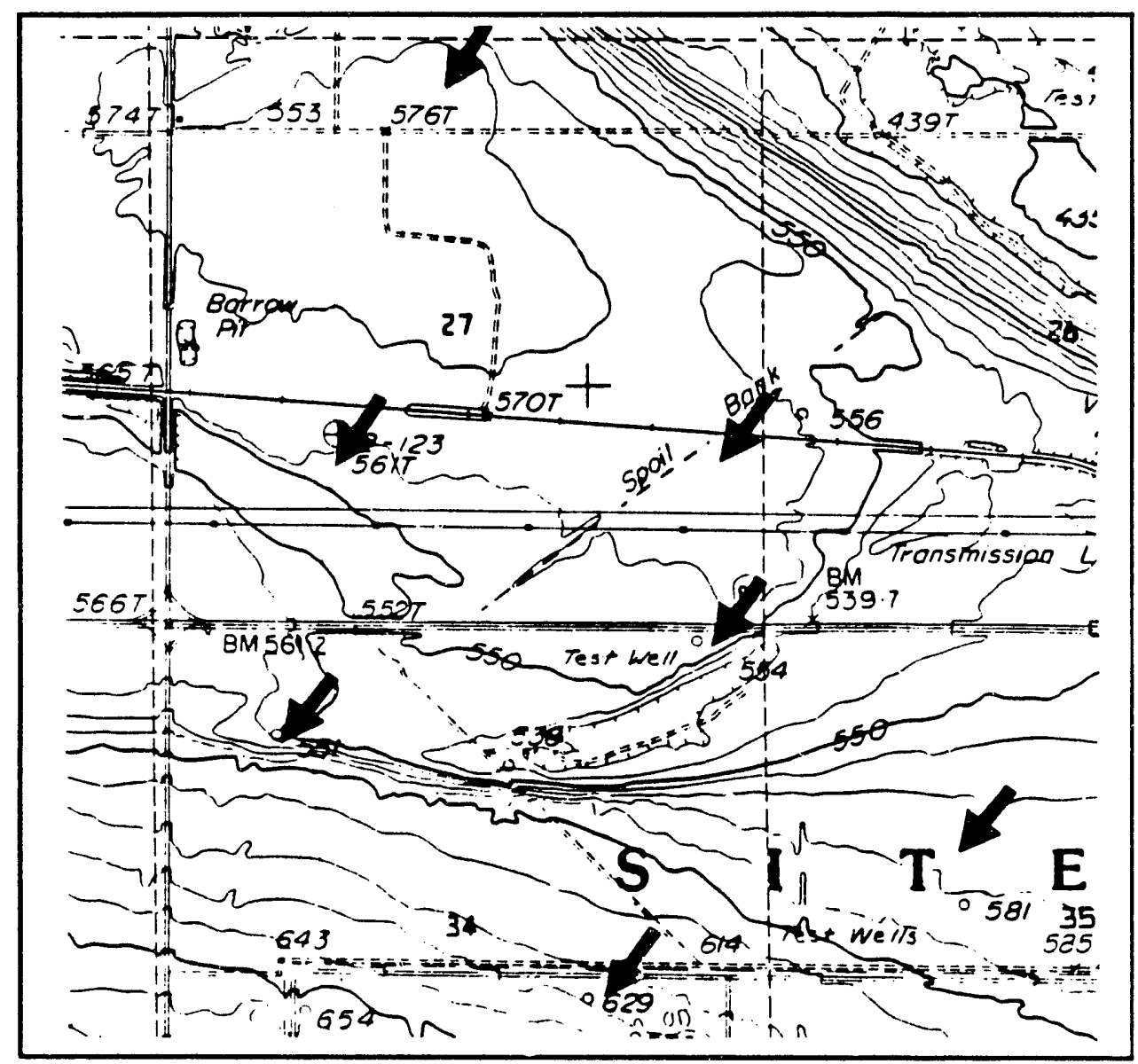

FIGURE A.27. Location of the Area Reviewed for the 200-BP-1 Groundwater Monitoring Wells, HCRC \#90-600-002 on a Portion of the USGS Gable Butte Quadrangle, Sec. 27, 34, and 35 T13N-R26E 
HCRC \#90-600-003

\section{SAVAGE ISLAND PROJECT MONITORING WELLS}

Requester: T. J. Gilmore

Environmental Sciences Department.

Pacific Northwest Laboratory

Richland, WA 99352

Project Description: Two additional monitoring wells were to be added to the Savage Island

Project. The first well was to be located directly east of Savage Island, in Section 3, Township 12 north, Range 28 east, and the second located adjacent to well 699-32-22, Section 15, Township 13 north, Range 27 east (Figure A.28). A review of litersture and records showed that no archaeological sites or culturally important properties were knowri to be located in the project area; however, because both well sites are on undisturbed ground, a pedestrian survey was required before ground disturbing activity began. On February 22, 1990, the areas were inspected by P. E. Minthorn using standard survey techniques as outlined in the Hanford Cultural Resources Management lan.

Cultural_Resources: No cultural resources were observed. 


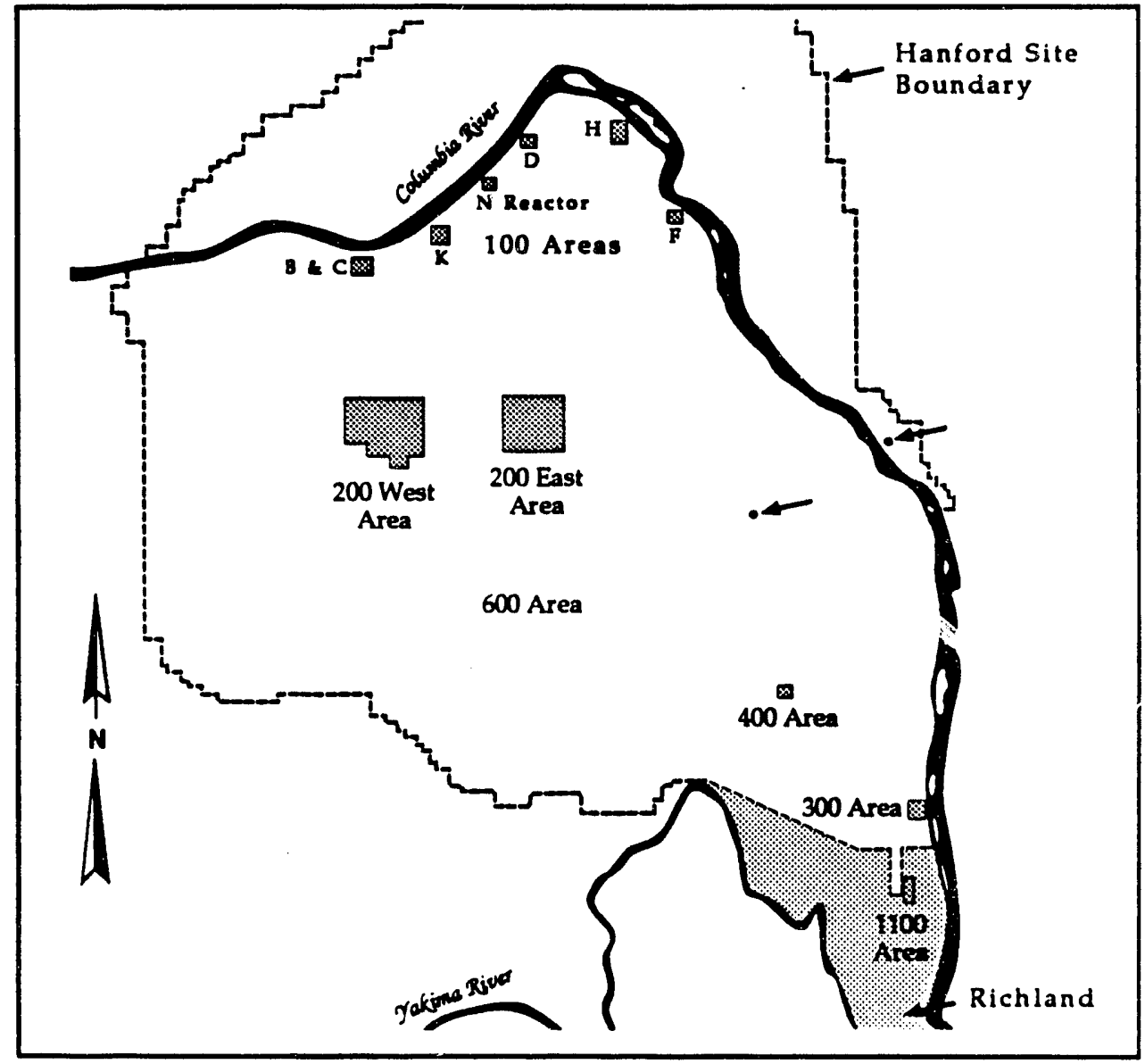

FIGURE A.28. Location of the Area Reviewed for the Savage Island Project Monitoring Wells, HCRC $\$ 90-600-003$ on a Portion of an HCRC Site Map (November 1990) 
HCRC \#90-600-006

\section{LIQUID EFFLUENT RETENTION FACILITY; DISPOSAL SURFACE SITE}

\section{EVALUATION}

Requester: Mr. Yule Sada

Environmental Engineering Group

Environmental Division

Westinghouse Hanford Company

Richland, WA 99352

Project Description: As part of the site selection process, four areas were under consideration for the location of disposal surface ponds designed to receive effluent from the Liquid Effluent Retention Facility. Two of the proposed areas, sites A and B, had heen previously surveyed, thereby making further evaluation unnecessary. Sites $C$ and D, located east of the 200 East Area, had never been surveyed for archaeological properties and were situated on largely undisturbed ground (Figure A.29). Therefore, field survey was required. A review of literature and records showed that no archaeological sites or culturally important properties were known to be located in the project area. On April 3, 1990, the area was inspected by P. E. Minthorn and H. A. Gard using standard survey techniques as outlined in the Hanford Cultural Resources Management Plan. Average ground cover for both areas ranged between $20 \%$ and $50 \%$.

Cultural Resources: One isolated artifact, designated HI-90-001, was recorded in Site D. The artifact was a solder sealed evaporated milk can circa 1915 to 1925 . Any pertinent information provided by this artifact has been collected. It is, therefore, not considered significant. 


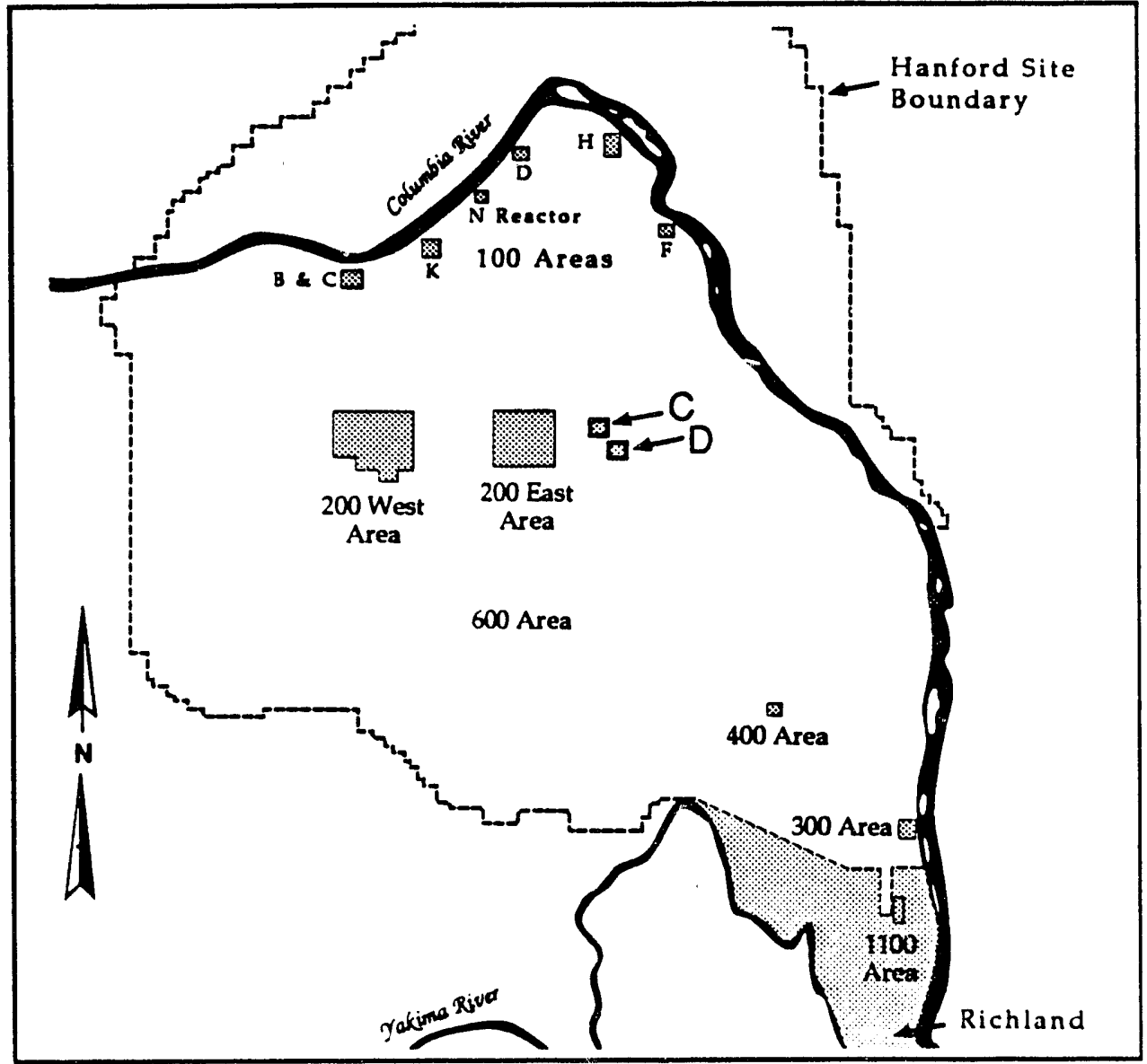

FIGURE A.29. Location of the Area Reviewed for the Liquid Effluent Retention Facility; Disposal Surface Site Evaluation, HCRC \#90-600-006 on a Portion of an HCRC Site Map (November 1990) 
HCRC \#90-600-010

\section{USGS ENVIRONMENTAL TRACER STUDY}

Requester: Mr. Ward Staubitz

US Geological Survey

Water Resources Division

1201 Pacific Avenue, Suite 600

Tacoma, WA 98402

Project Description: As part of a hydrologic investigation to test the applicability of using isotopic and environmental tracers to quantify groundwater recharge, the USGS identified three areas to place numerous test trenches and boreholes. Trenches would disturb a minimum area of $2 \mathrm{~m}$ by $5 \mathrm{~m}$ by $2 \mathrm{~m}$ deep. Boreholes would average $10 \mathrm{~m}$ in depth. Two of the areas were located north of Benson Spring, and the remaining site was situated west of McGee Ranch (Figure A.30). Because these areas had never been surveyed for archaeological properties and were situated on largely undisturbed ground, field inspection was required. A review of literature and records showed that no archaeological sites or culturally important properties were known to be located in the project areas. On April 25, 1990, the area was inspected by P. E. Min horn using standard survey techniques as outlined in the Hanford Cultural Rescurces Management Plan.

Cultural Resources: No historic or culturally significant properties were located. 


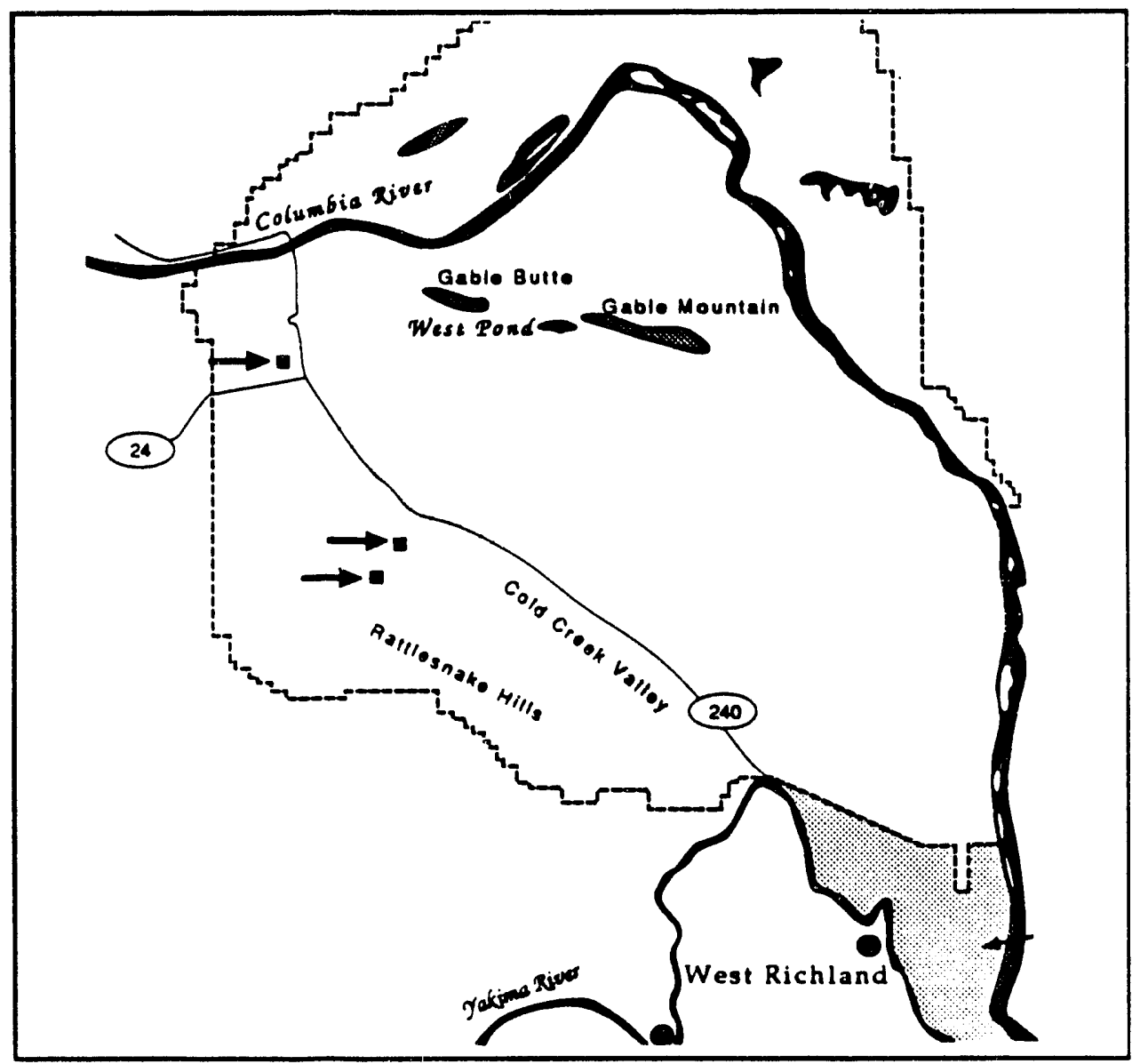

FIGURE A.30. Location of the Area Reviewed for the USGS Environmental Tracer Study, HCRC \#90-600-010 on a Portion of an HCRC Site Map (November 1990) 
HCRC \#90-600-011

\section{USGS REGIONAL EVAPOTRANSPIRATION STUDY}

Requester: Mr. Stewart A Tomlinson

US Geological Survey

Water Resources Division

1201. Pacific Avenue, Suite 600

Tacoma, WA 98402

Project Description: As part of an ongoing hydrologic characterization investigation, two locations on the Arid Lands Ecology Reserve were identified by the USGS for installation of three monitoring stations. Installation of each station disturbed a $0.46 \mathrm{~m}^{2}$ area. The two areas are located south of Snively Spring, in Section 8, T11N, R24E (Figure A.31). Because these areas had never been surveyed for archaeological properties and were situated on undisturbed ground, field inspection was required before construction of the stations. A review of literature and records showed that no archaeological sites or culturally important properties were known to be located in the project areas. On April 24, 1990, the area was inspected by P. E. Minthorn using standard field techniques.

Cultural Resources: No historic or culturally significant properties were located. 


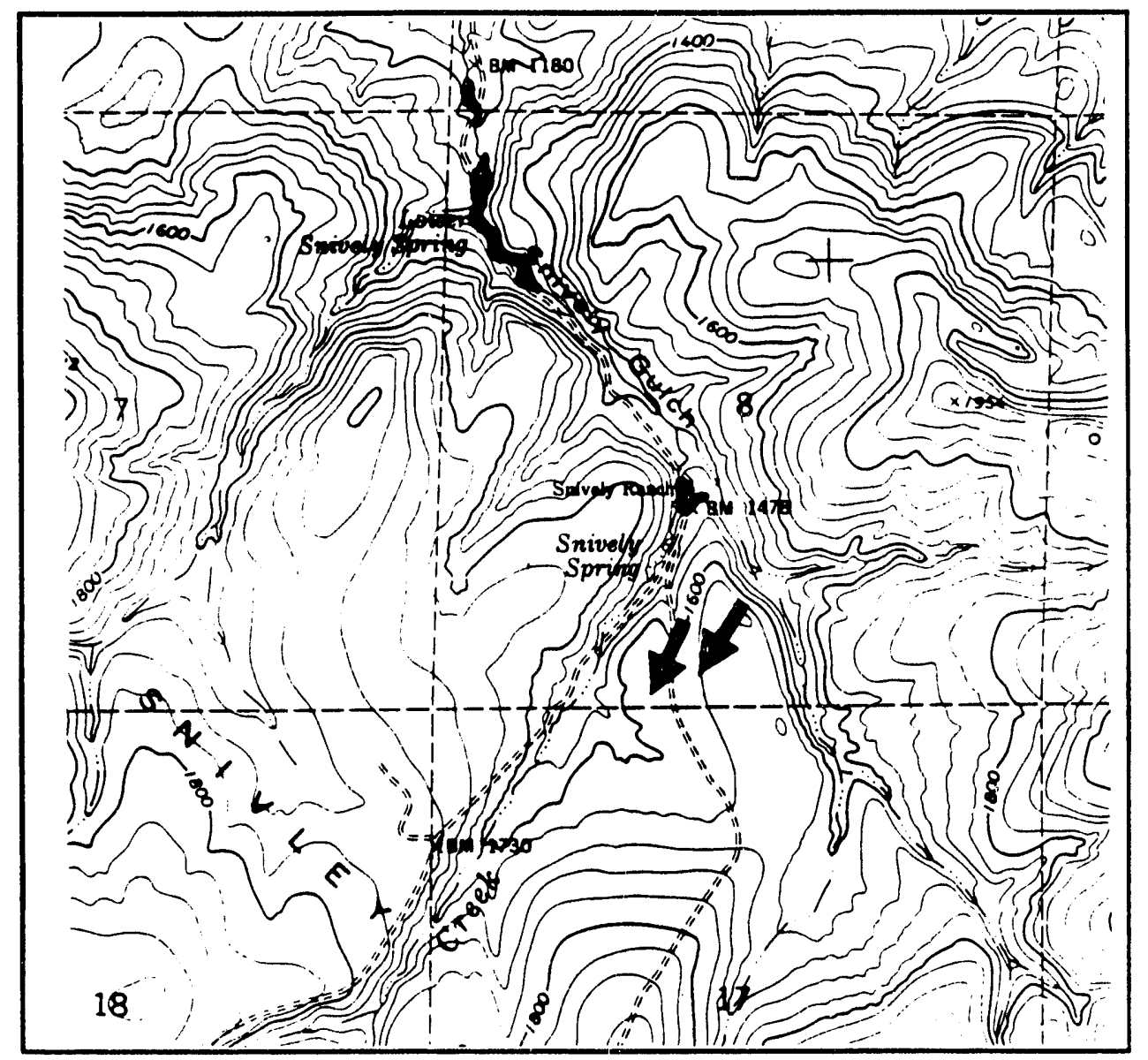

FIGURE A.31. Location of the Area Reviewed for the USGS Regional Evapotranspiration Study, HCRC \#90-600-011 on a Portion of the USGS Snively Basin Quadrangle, Sec 8 T11N-R24E 
HCRC \#90-600-012

\section{WASHINGTON PUBLIC POWER SUPPLY SYSTEM (WPPSS) FIBER OPTIC TELECOMMUNICATIONS CABLE INSTALLATION}

\section{Requester: Mr. Brian C. Harmon \\ Landlord Projects \\ Westinghouse Hanford Company \\ Richland, WA 99352}

Project Description: As part of a telecommunications upgrade, a fiber optic cable was installed from the WPPSS headquarters at 3000 George Washington Way to WPPSS Nuclear Plant Number 2 situated on the Hanford Site (Figure A.32). The cable corridor route runs roughly parallel to the railroad tracks, $7.6 \mathrm{ft}$ from the track centerline. Cable installation disturbed a 3-m-wide path to a depth of $1.8 \mathrm{~m}$. A 4-km section of the cable corridor, extending from WPPSS headquarters to the intersection of Horn Rapids Road and Stevens Drive, had either been previously surveyed or was situated in previously disturbed areas. It was, therefore, not subject to a pedestrian survey. A 13.3-km section, extending north from the intersection of Horn Rapids Road and Stevens Drive to the WPPSS security fence, was situated in an undisturbed area and a survey was necessary before cable installation. A review of literature and records showed that no archaeological sites or culturally important properties were known to be located in the project area. On July 25, 1990, P. E. Minthorn surveyed the area using techniques outlined in the Hanford Cultural Resources Management Plan.

Cultural Resources: One isolated artifact, designated HI \#90-011, was recorded. The artifact was an Oregon license plate dating from 1925, which has been collected. This item is not considered significant and no further action is necessary. 


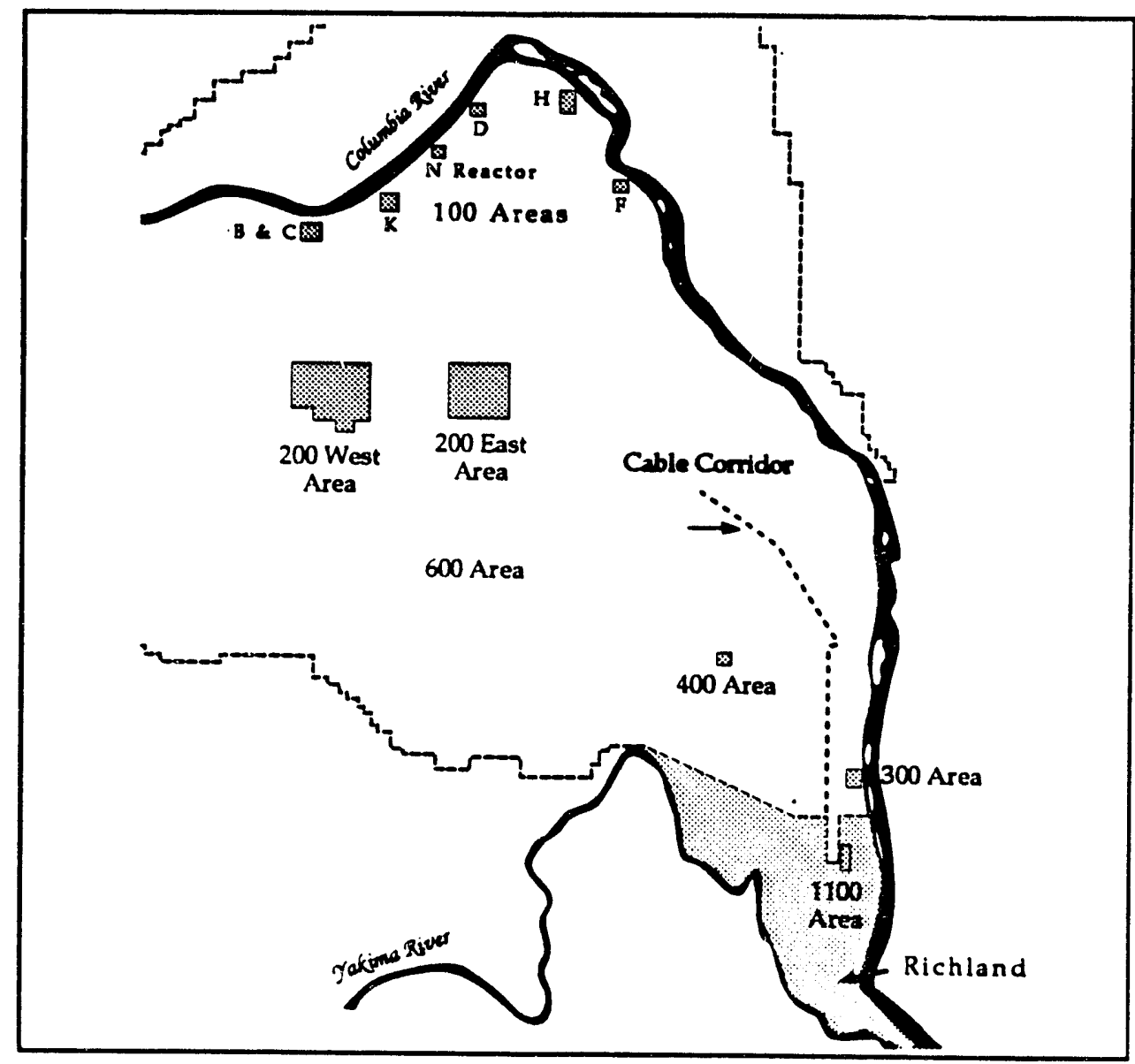

FIGURE A.32. Location of the Area Reviewed for the WPPSS Fiber Optic Telecommunications Cable Installation HCRC \#90-600-012 on a Portion of an HCRL Site Map (November 1990) 


\section{HCRC \#90-600-015}

\section{PROTOTYPE BARRIER PERFORMANCE TESTING}

Requester: Mr. Steve Phillips

Environmental Technology

Westinghouse Hanford Company

Richland, WA 99352

Project Description: A $200 \mathrm{~m}^{2}$ area was to be extensively disturbed to a depth of $5 \mathrm{~m}$ by construction of a prototype surface engineered barrier designed for the long-term storage of high level radioactive waste. The barrier is to be located at the northeast corner of the 200 West Area, directly north of the $622 \mathrm{G}$ Building (Figure A.33). Because the area was previously undisturbed, a cultural resource survey was required before construction could begin. A review of literature and records showed that no archaeological sites or culturally important properties were known to be located in the project area. On June 19, 1990, the area was inspected by P. E. Minthorn using standard survey techniques as outlined in the Hanford Cultural Resources Management Plan.

Cultural Resources: No cultural resources were located. 


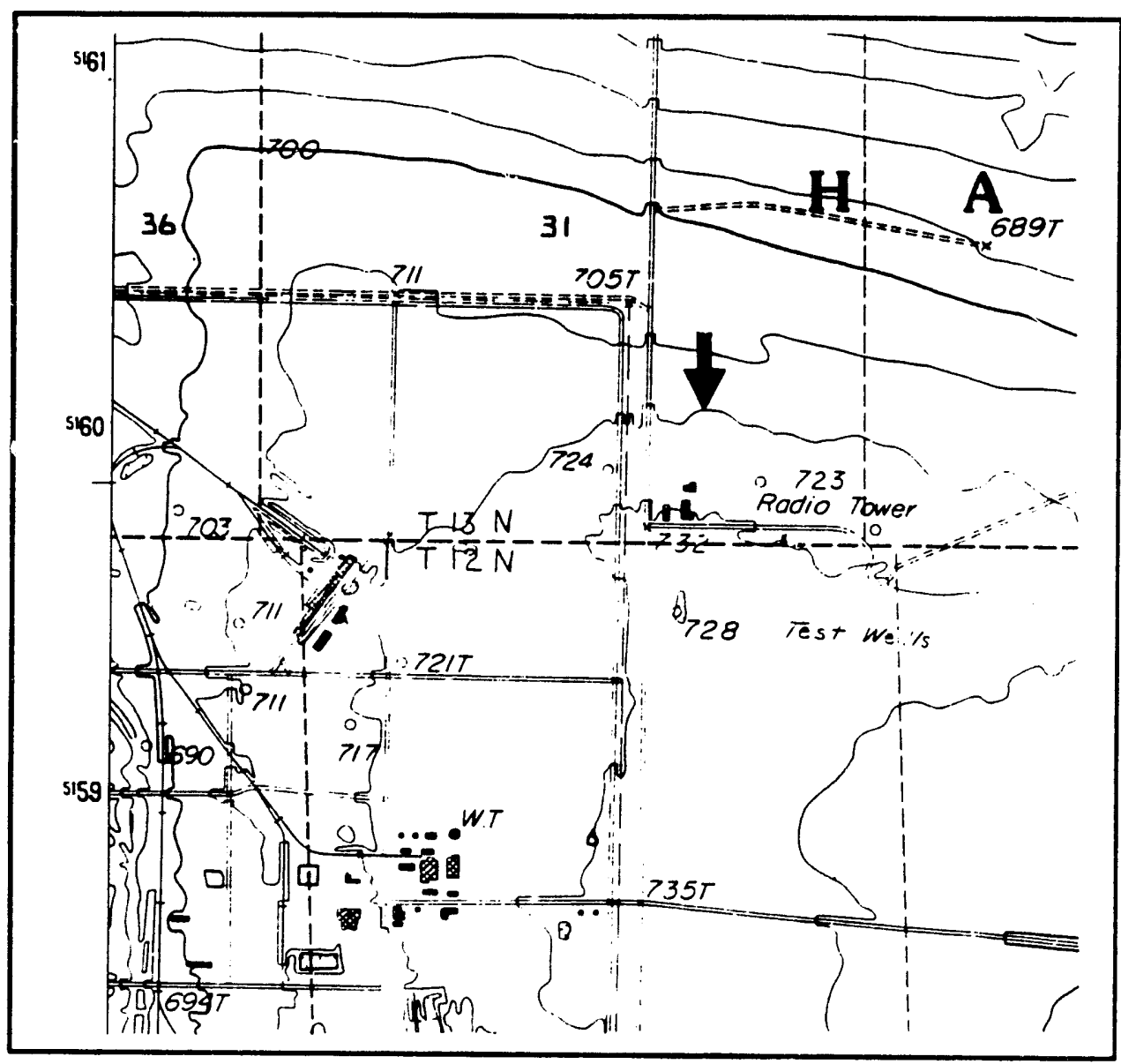

FIGURE A.33. Location of the Area Reviewed for the Prototype Earrier Performance Testing, HCRC \#90-600-015 on a Portion of the USGS Gable Butte Quadrangle, Sec. 31 T13N-R26E 


\section{HCRC \#90-600-016}

\section{ATMOSPHERIC BOMB TEST SAMPLING}

Requester: Mr. Steve Phillips

Environmental Technology

Westinghouse Hanford Company

Richland, WA 99352

Project Description: As part of a project designed to assess the amount of background radiation that has accumulated from aboveground nuclear bomb tests, seven soil sample test pits and boreholes were placed in undisturbed areas across the Hanford Site (Figure A.34). Each test pit would impact an area measuring $35 \mathrm{~m}^{2}$ and $3.5 \mathrm{~m}$ deep, while the boreholes would impact a minimum area of $5 \mathrm{~m}^{2}$ by $40 \mathrm{~m}$ in depth. A review of literature and records showed that only the McGee Ranch collection site contained known historic properties. As outlined in the Hanford Cultural Resolirces Management Plan for Class V cases, a pedestrian survey was performed for each collection site by P. E. Minthorn on September 18, 1990. A 50- $\mathrm{m}^{2}$ area around each collection site was inspected using techniques outlined in the Hanford Cultural Resources Management Plan.

Cultural Resources: Only at the McGee Ranch collection site were historic properties encountered. These consisted of underground wooden irrigation pipes, open irrigation ditches, abandoned fields, and other associated farm features. None of these properties are considered eligible for nomination to the National Register because of their lack of integrity and the prevalence of these types of features throughout Eastern Washington. Workers were, however, requested to avoid, wherever possible, obvious features in an attempt to prevent unnecessary damage to the property. 


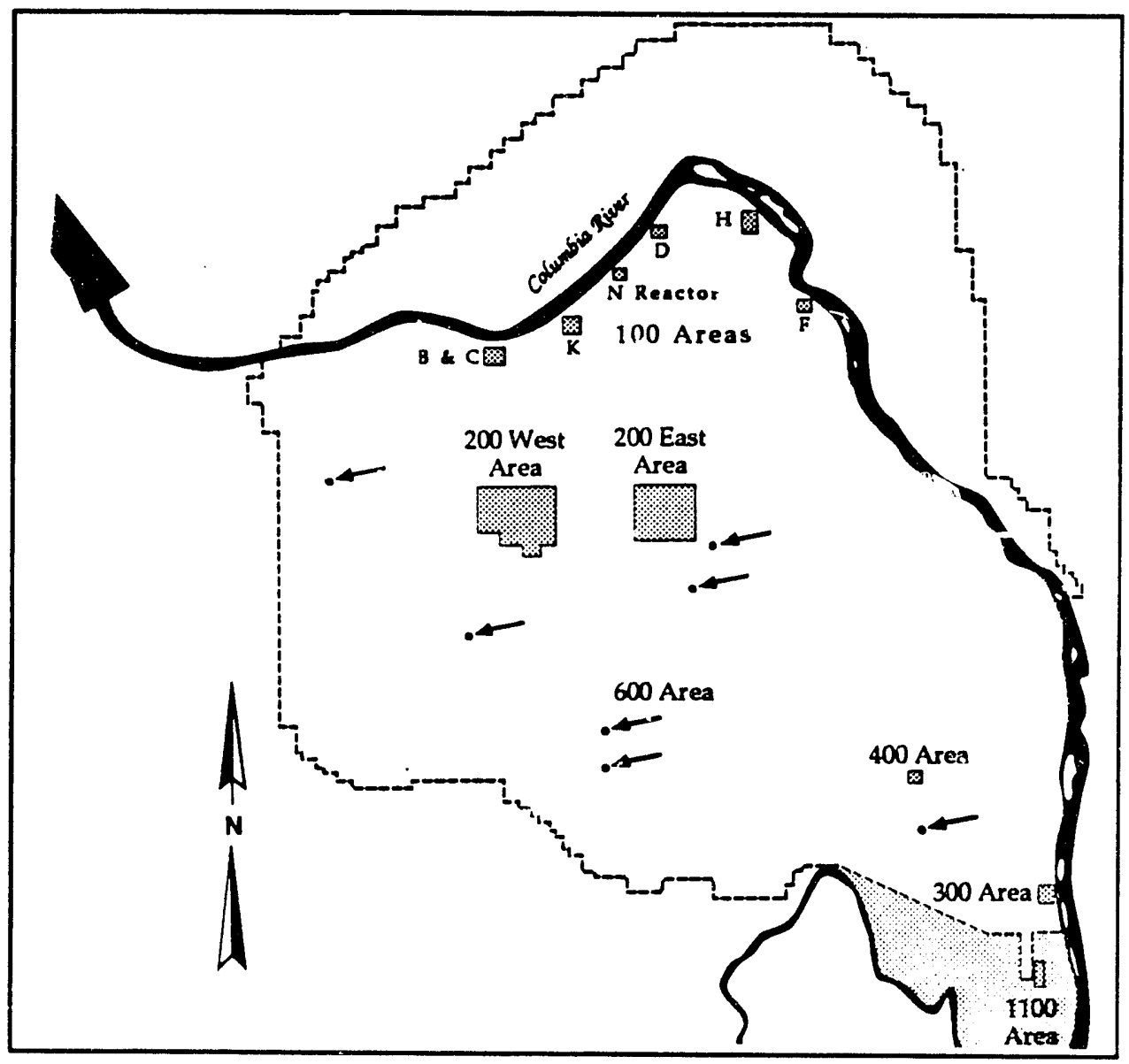

FIGURE A.34. Location of Areas Reviewed for the Atmospheric Bomb Test Sampling, HCRC \#90-600-016 on a Portion of an HCRL Site Map (November 1990) 
HCRC \#90-600-017

DEEP MICROBIOLOGY SAMPLING

Requester: Mr. Bruce Bjornstad

Environmental Sciences Department

Pacific Norti west Laboratory

Richland, WA 99352

Project Description: As part of a project designed to 1ocate and identify subsurface microorganisms, a single 106.7-m-deep borehole was drilled approximately $1.4 \mathrm{~km}$ east of the Yakima Barricade (Figure A.35). The drilling pad required for this project impacted an undisturbed area of $100 \mathrm{~m}^{2}$. An additional $40-\mathrm{m}$-wide by 250 -m-long access corridor, extending from the drill pad to Highway 4 , was disrupted by construction equipment. A review of literature and records showed that no known archaeological, cultural, or historic properties were located in the project aria. As outlined in the Hanford Cultural Resources Management Plan for Class V cases, a pedestrian survey was performed at the drill site by P. E. Minthorn on June 14, 1990, using standard techniques.

Cultural Resources: No cultural resources were located within the project area. 


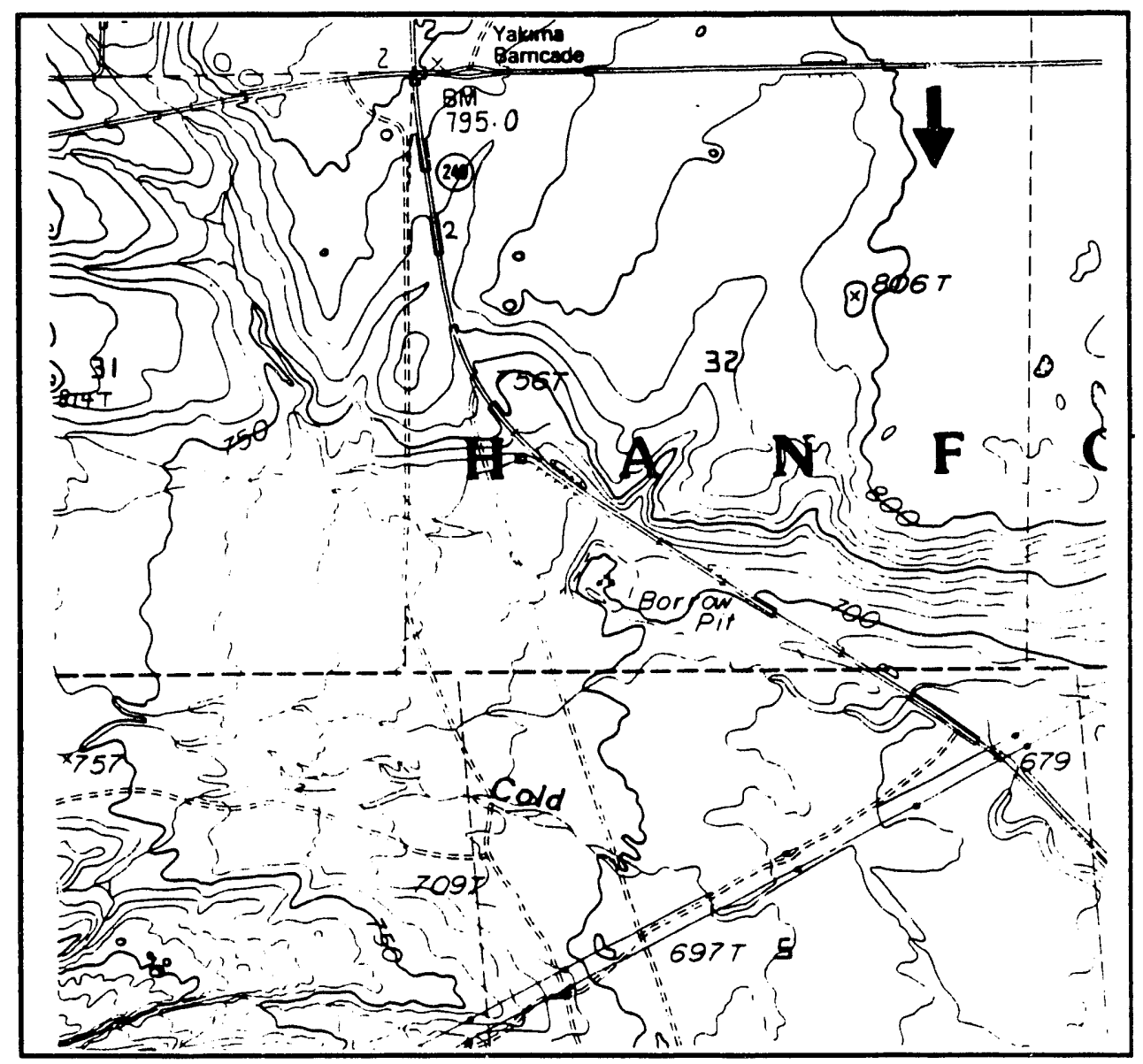

FIGURE A.35. Location of the Area Reviewed for the Deep Microbiology Sampling, HCRC \#90-600-017 on a Portion of the USGS Riverland Quadrangle, Sec. 32 T13N-R25E 
HCRC \#90-600-018

DUNE FORMATION CHARACTERIZATION STUDY

Requester: G. Smith Terrestrial Sciences

Pacific Northwest Laboratory

Richland, WA 99352

Project Description: As part of a dune formation characterization study, 31 test pits were excavated, measuring $1.0 \mathrm{~m}^{2}$ and 1.0 to $1.5 \mathrm{~m}$ deep. An addicional 20 auger tests were made, measuring $5 \mathrm{~cm}$ in diameter and $1.0 \mathrm{~m}$ deep for a total of 51 individual test sites. These test pits were located throughout the active and inactive dune fields in the 600 Area of the Hanford Site (Figure A.36). Literature and records did not reveal the presence of any known cultural properties within the project area. Because all of these pits were to be located in undisturbed soils, however, monitoring of excuvations was required. In this unique instance the individual conducting the study had extensive archaeological experience. As a NORCUS student assigned to the HCRL, he was given permission to monitor his own excavations under the express understanding that a senior member of the HCRL was to be notified immediately if any cultural material was uncovered.

Cultural Resources: No cultural remains were located. 


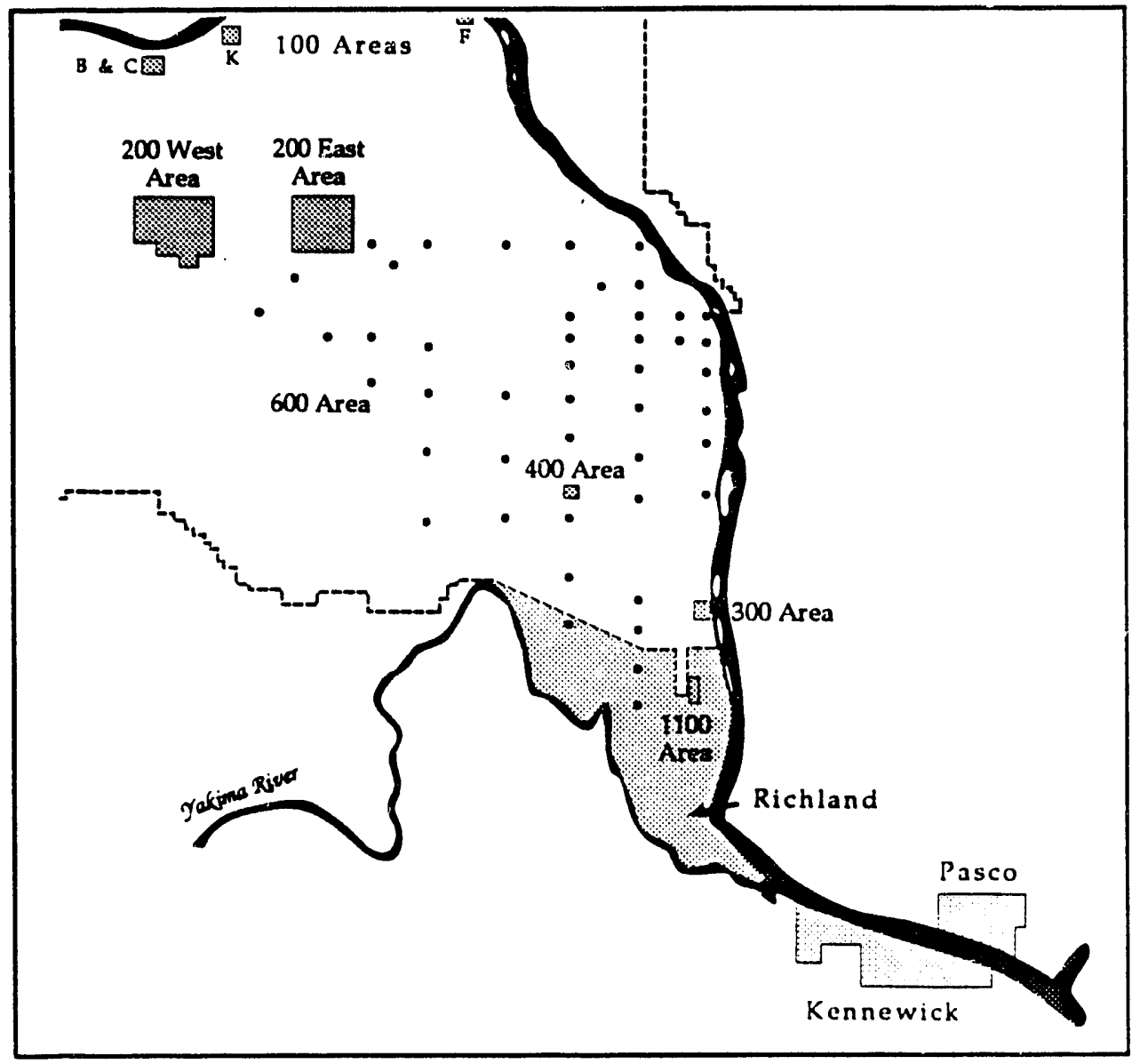

FIGURE A.36. Location of the Area Reviewed for the Dune Formation Characterization Study, HCRC \#90-600-0 i 8 on a Portion of an HCRL Site Map (November 1990) 


\section{WHCRC \#90-600-019}

\section{BARRIERS BASALT RIP RAP QUARRY}

\section{Requester: N. R. Wing \\ Environmental Technology Group \\ Westinghouse Hanford Company \\ Richland, WA 99352}

Project Description: To provide material for the construction of a prototype barrier, an abandoned quarry, located in a basalt outcrop situated between the Yakima Barricade and Vernita Bridge, was reopened (Figure A.37). Given the cultural importance of natural basalt outcrops to native groups within the region, and the high probability of encountering archaeological sites upon features such as this, a cultural resources review and survey was required prior to the commencement of construction activity. A review of literature and records showed that no known archaeological, cultural, or historic properties were located in the project area. The area was surveyed by H. A. Gard on June 29, 1990, using field techniques outlined in the Hanford Cultural Resources Management Plan for Class IV cases.

Cultural Resources: Several low, two-to three-course, rock walls were located along the top of the outcrop's cliff edge. It was determined that these were of fairly recent origin based on the lack of lichen development on the stones, their placement on a cliff face newly formed by quarry activity, and by their association with neoteric debris. It is likely that these features date from the 1950s or early 1960s and are associated with U.S. Department of Defense activities. Given the age and association of these features it is determined that they are ineligible for nomination to the National Register and are no longer of concern. No other cultural properties wert iscated in the project area. 


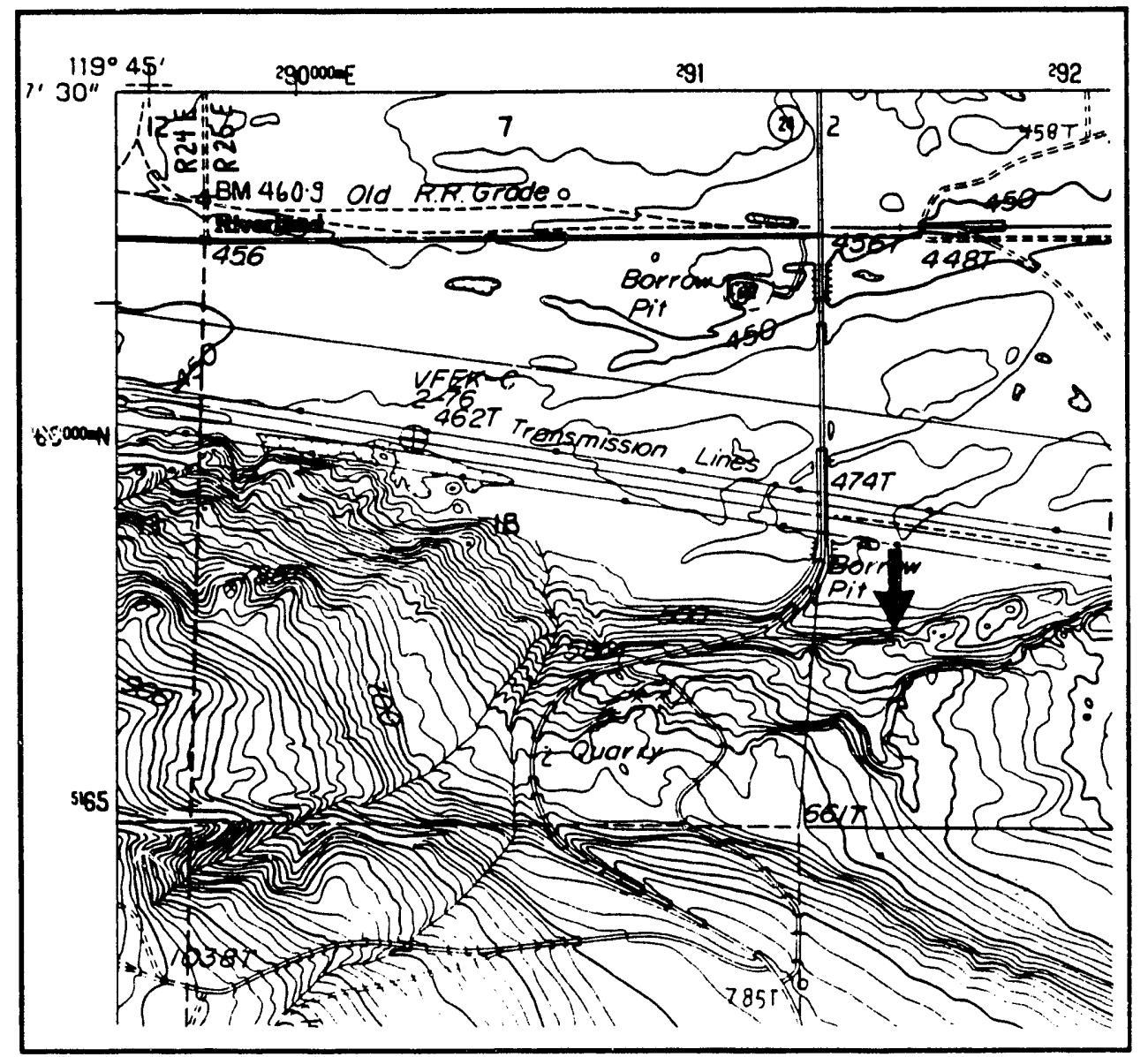

EIGURE A.37. Location of the Area Reviewed for the Barriers Basalt Rip Rap Quarry, HCRC \#90-600-019 on a Portion of the USGS Riverland Quadrangle, Sec. 18 T13N-R25E 
HCRC \#90-600-023

W-058 REPLACEMENT OF CROSS-SITE TRANSFER LINE

Requester: E. T. Trost

Defense Waste

Project Engineering

Westinghouse Hanford Company

Richland, WA 99352

Broject Description: A portion of a replacement cross-site transfer line, to be constructed between the 200 East and 200 West Areas, will impact undisturbed ground (Figure A.38). The eastern area of potential effect has been previously surveyed as HCRC \#89-600-010, Project L-006 (Rt 3/4S intersection Safety Improvements, see Figure A.14). The remaining 30-m-wide and 6400 -m-long corridor required a pedestrian survey before work could commence. A review of literature and records showed that no archaeological sites or culturally important properties were known to be located in the project area. On July 26, 1990, the area was inspected by P. F. Minthorn using standard survey techniques as outlined in the Hanford Cultural Resources Management Plan.

Cultural Resources: No cultural resources were observed. 


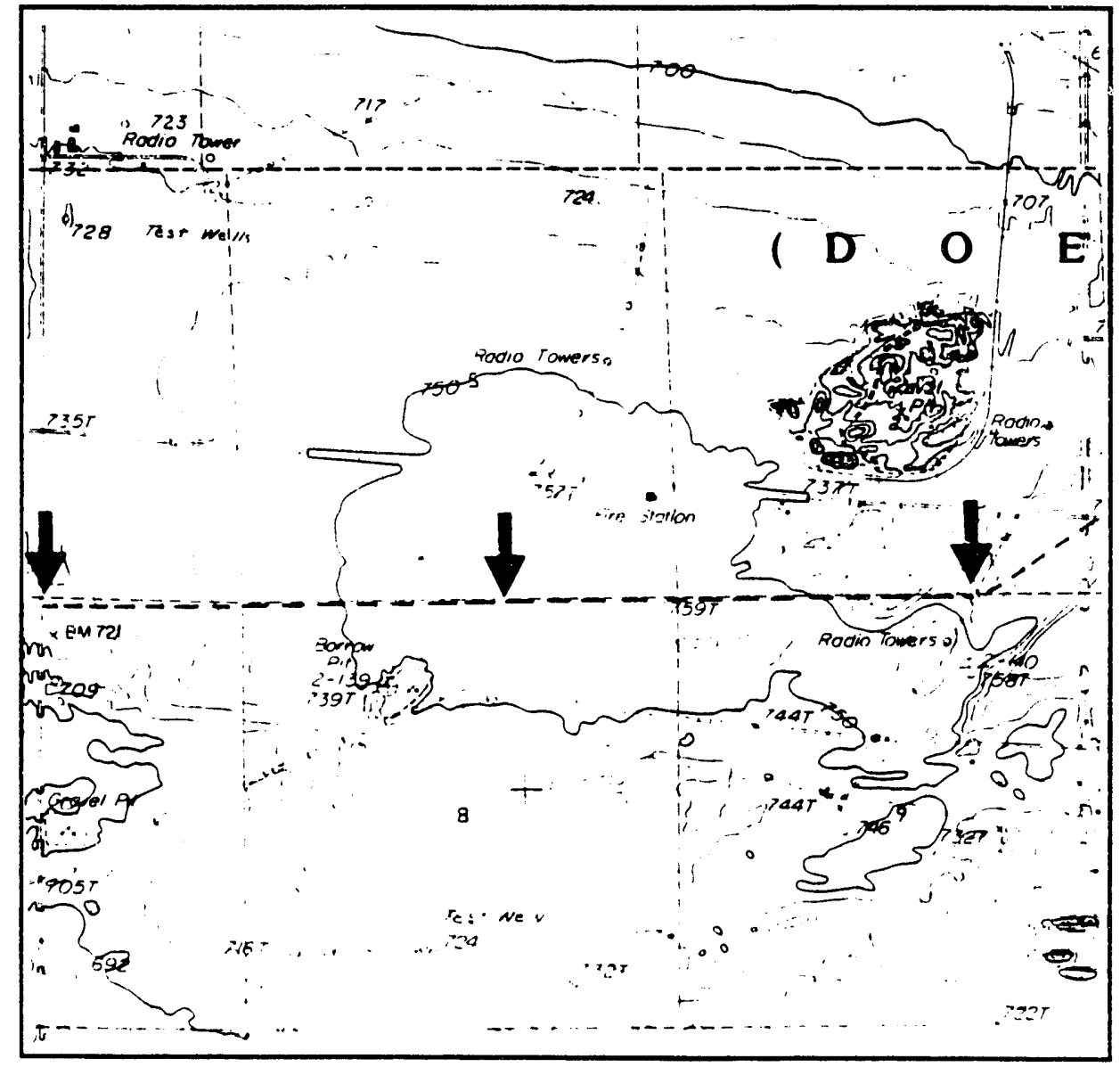

FIGURE A.38. Location of the Area Reviewed for the W-058 Replacement of Cross-Site Transfer Line, HCRC \#90-600-023 on a Portion of the USGS Gable Butte Quadrangle, T12N-R26E 
HCRC \#90-1100-002

CERCLA GROUNDWATER MONITORING WELLS, MW-2 AND MW-17

Requester: B. L. Gilkeson

Defense Waste Management

Environmental Division

Westinghouse Hanford Company

Richland, WA 99352

Proiect Description: This project involved plans to install two groundwater monitoring wells within the Kaiser Engineers laydown yard and in the 1100 Area of the Hanford Site (Figure A.39). The project dimensions for each well head included $20 \mathrm{~m}^{2}$ of direct disturbance with drilling depths between 27 and $36.5 \mathrm{~m}$. A review of literature and records showed that no archaeological sites or culturally important properties were known to be located in the project areas. Well number MW-17 is situated in a previously disturbed area and, therefore, no additional work was required. Well number MW-2 is situated on undisturbed sediments and therefore a pedestrian survey was necessary before drilling could begin. On January 9, 1990, the area was inspected by N. A. Cadoret, who walked $20-\mathrm{m}$-spaced transects within a $105 \mathrm{~m}$ by $80 \mathrm{~m}$ area. The well is situated in an area of stabilized dunes and the ground cover averaged $40 \%$.

Cultural Resources: No cultural resources were located. 


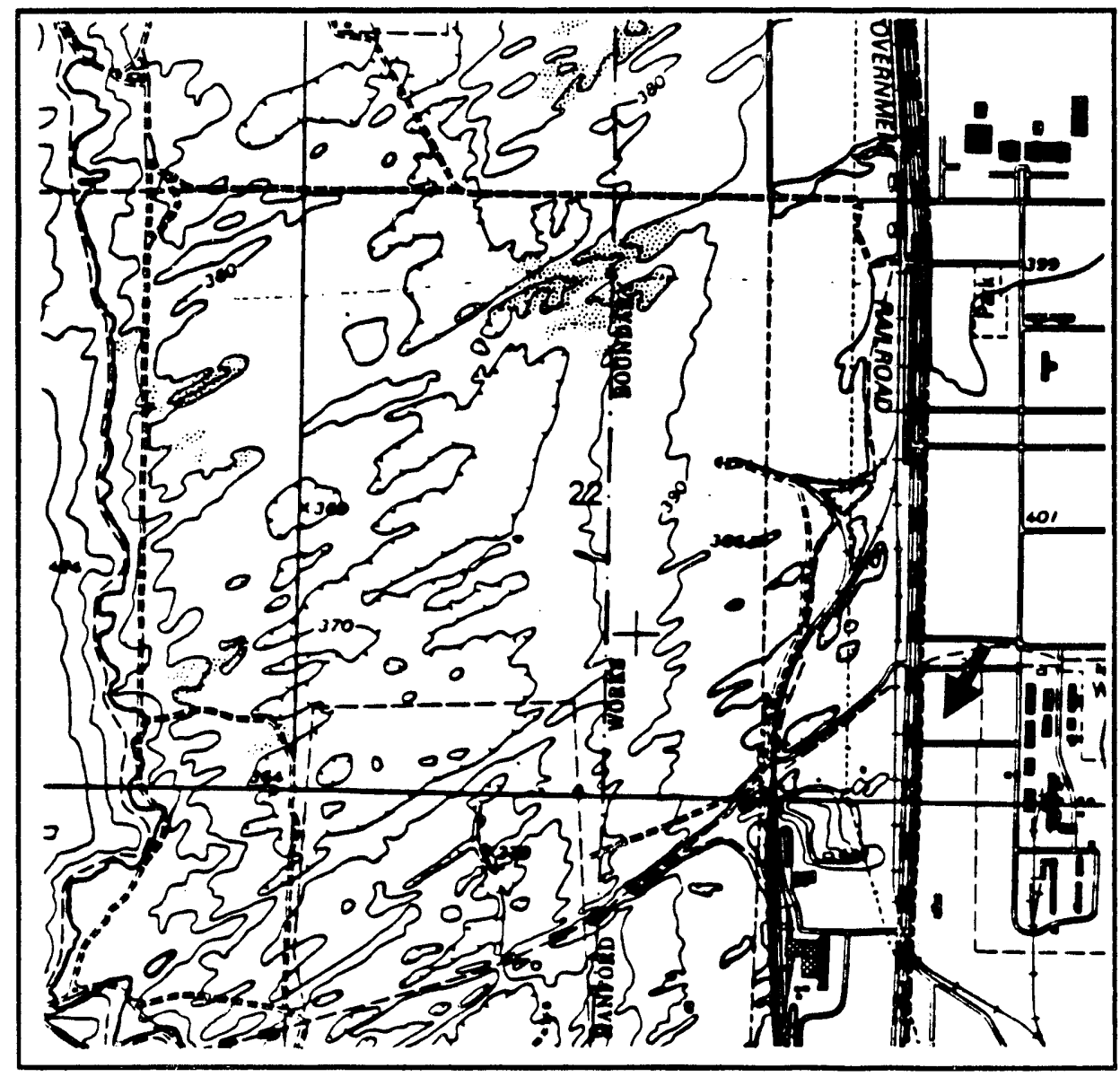

EIGURE A.39. Location of the Area Reviewed for the 1100 Area CERCLA Groundwater Monitoring Weils, MW-2 and MW-17, HCRC \#90-600-023 on a Portion of the USGS Richland Quadrangle, T20-R28E 


\section{A.3 REFERENCES}

Chatters, J. C., ed. 1989. Hanford Cultural Resources Management Plan. PNL-6942, Pacific Northwest Laboratory, Richland, Washington.

ERTEC. 1982. A Cultural Resources Overview and Scenic and Natural Resources Assessment for the Skagit-Hanford Nuclear Power Project. ERTEC Northwest, Seattle, Washington. 
APPENDIX E

CULTURAL RESOURCES MONITORING

OBSERVATIONS FOR THE FY 1990 MONITORING CYCLE 


\section{APPENDIX B}

\section{CULTURAL RESOURCES MONITORING OBSERVATIONS FOR THE}

\section{FY 1990 MONITORING CYCLE}

\section{B.1 CEMETERIES}

45BN124. Disturbance is principally from occasional vehicles that are restricted to the road adjoining the site. There is ongoing wind erosion of the dune, but no human remains have been exposed.

45BN128. The island showed evidence of recent trespass. However, the site demonstrated no sign of disturbance. Only one fragment of human bone was visible on the ground surface. The site continues to be eroded by wind.

45BN129. This site is located on an unnamed island below the White Bluffs boat ramp. The island is close to the west bank of the river and is dissected by numerous old river channels, which creates a rugged undulating topography. The site is located on an isolated promontory toward the southern end of the island. It was described by Rice (1968) as a single-flexed burial site with no associated artifacts eroding out of a sand dune, and no mention was made of an associated cairn or grave covering. The dune has since become stabilized and no sign of human remains was encountered. Exposed in the terrace profile, covered by over $1.0 \mathrm{~m}$ of wind-blown sand, at least four hearth features and one very distinct house pit were recorded. The site encompasses an area $80 \mathrm{~m}$ $\mathrm{N} / \mathrm{S}$ by $60 \mathrm{~m} \mathrm{E} / \mathrm{W}$ and is separated from Site $45 \mathrm{BN} 130$ by an old river channel. Sites $45 \mathrm{BN} 130$ and 45BN129 were formerly a single site and so the two were mapped together. Based on Rice's (1968) description it seems that the burial he discovered was more recent than the buried house-pits (based upon their relative stratigraphic positions). No diagnostic artifacts were located and there was no evidence of recent disturbances. Natural erosion is the principal destructive process and is the most likely cause for the removal of the burial. This was the first inspection since the site was originally recorded. (See discussion of Site 45BN130 under Register Sites.)

45BN140/139. Based on last year's monitoring and evaluation, Site 45BN139 is now considered an extension of Site 45BN140. Fragments of the same skeletal elements identified last year were rediscovered during this field season. Both fragments demonstrated signs of considerable 
additional decomposition. Wind and water erosion is still evident around the margins of the blowout. However, signs of anthropogenic disturbance were absent.

45BN142. This site is located at the mid-point and northern edge of an unnamed island. Described by Rice (1968) as a house-pit site from which a skull had been discovered, it was included as a burial site during this season's monitoring. The original site descriptions listed two to three house depressions, tool caches, and concentrations of fire-cracked rock (FCR). Currently the site is covered by dense vegetation and the only visible clue to the site's location is the presence of FCR and hopper mortar bases distributed along the shoreline below the site. There was no sign of anthropogenic disturbance and terrace erosion had been stabilized by the vegetation. This site is well concealed and hence protected. This was the site's first evaluation under the monitoring program.

45BN143. This site is confined to a large blowout in the center of the same island on which Site 45BN142 is located. Deflated by wind, extensive concentrations of both prehistoric and historic artifacts attest to this site's contact period age. The site measures $90 \mathrm{~m} \mathrm{E} / \mathrm{W}$ by $50 \mathrm{~m} \mathrm{~N} / \mathrm{S}$, and contains an elongated rock cairn measuring $1 \mathrm{~m}$ by $2 \mathrm{~m}$, constructed with fist-sized FCR. Additionally, concentrations of heat treated cryptocrystalline (CCS) flakes, caches of cobble tools, freshwater mussel shell, fragmentary large mammal bone, and historic artifacts such as buckets, buckles, and cans occur across the site. Three human bone elements, a lumbar vertebra, the distal end of a left femur, and a tarsal were noted eroding from the dune edge. There was no evidence of any anthropogenic disturbance. However, the lack of diagnostic artifacts, e.g., projectile points, suggests that surface collecting has occurred in the past. Currently, the only degenerative process is natural erosion and decomposition of organic material. This was the first time this site had been evaluated under the monitoring program.

45BN151. As with last year, no evidence of archaeological material was visible within the two separate sets of marking signs. Furthermore, there was no sign of any disturbance, either anthropogenic or from natural erosion. The only recommendation is to replace the "DO NOT EXCAVATE" signs, which have begun to deteriorate, around the second set of markers. A frequently used road bisects this site.

45BN157b. As a result of last year's monitoring recommendation that this site needed extra protection because of visibility, public access, and its long history of vandalism, a 2.4-m-high cyclone security fence was erected around the site. When revisited this year prior to fishing 
season, it was discovered that the fence gate had been intentionally rammed by a vehicle, creating a large enough gap between the fence and the gate post that pedestrian traffic could easily pass through. Inspection of the site revealed evidence of recent looter excavations. Unrelated to this intentional vandalism, wind and water erosion has been extensive since last fall, and has exposed portions of a human skull. With the evidence of continuing trespassing, the potential for intentional grave desecration remains high. Although the site has been fenced and is clearly marked with Department of Energy "NO TRESPASSING" signs, it is clear that this is not a deterrent to determined looters. While the gate can be repaired and even strengthened, certainly new means of access will be devised, given time. It would seem that the best hope for preventing destruction of this important cultural resource is increased patrolling and, ideally, a well-publicized conviction for violation of ARPA laws.

45GR302c. Described by Rice (19 $\left.{ }^{3}\right)$ as a camp site, this site is also repc red as an historic Wanapum burial ground and is therefore included here. This site has not been previously investigated by Hanford Cultural Resource Laboratory (HCRL) staff and is not listed on the original nomination form for the Locke Island Archaeological District. It is located on the western bank of Locke Island. The original description listed only the presence of dense concentrations of FCR along the bank, accompanied by cobble tools, net weights, and pestles. Along the bank this description proved accurate. However, just inland from this artifact concentration, upon a natural levee, 12 to 14 extremely large and well preserved house pits were encountered. The largest of these was over $1.5 \mathrm{~m}$ deep and was approximately $13 \mathrm{~m}$ in diameter. Aeolian deposition had obscured the original ground surface, thereby effectively sealing these houses and covering surface artifacts. There was no evidence of any anthropogenic disturbance and no sign of burials. Time constraints prevented complete recording of this site, and it is recommended that this site be fully recorded, evaluated, and nominated to the National Register as part of the Locke Island Archaeological District.

45GR306c. This season's visit to the site revealed no new disturbances or information that can be added to that collected during mapping and test excavations conducted last year. Its use as a salmon and sturgeon fishing spot continues, and culturally modified rocks have been used to construct pole holders along the bank. Increased surveillance appears necessary.

45GR317. While no new disturbance was revealed during this year's reevaluation of the Paris site, with the exception of slight surface collecting, a new component to the site was discovered that increases both the site's complexity and its research value. Probably because previous 
reconnaissance was conducted during periods of high water, a series of regularly spaced circular depressions along the shoreline fronting the site proper had not been noted or reported. Seventeen depressions, both above the current waterline and directly below it, were recorded. They averaged $50 \mathrm{~cm}$ deep and approximately $4 \mathrm{~m}$ in diameter and were formed by displacing rocks outward to form a low berm around a basin. Shoreline features such as these are not reported in the available literature, but appear similar to depressions recorded last year by HCRL staff at Site 45BN118. It was hypothesized at that time that those depressions were correlated with shoreline springs. While this may also be the case at Site 45GR317, the density and extremely low position of the depressions at this locality make this interpretation seem unlikely. More research into these and other unreported shoreline features is required.

\section{B.2 SITES LISTED ON THE NATIONAL REGISTER OF HISTORIC PLACES}

\section{B.2.1 Wooded Island Archaeological District}

45BN041. This site is described as being located on the southern end, west bank, of Wooded Island. Despite extensive ground coverage, this site could not initially be located. By following the verbal description provided by Drucker (1948), an area on the first terrace, southwest edge of the Island, was located that appeared to have between five and eight circular to ovoid depressions averaging $5 \mathrm{~m}$ in diameter. No artifacts, however, were located in the proximity of these features, but this can be attributed to the presence of dense grasses and continuous aeolian deposition. The original description did state that the house pits had been filled with nearly $1 \mathrm{ft}$ of sand. The area covered by the depressions is $50 \mathrm{~m} \mathrm{~N} / \mathrm{S}$ by $15 \mathrm{~m} \mathrm{E} / \mathrm{W}$. Other aspects of the original description include the discovery of numerous artifacts such as mortars, pestles, mauls, knives, sinkers, scrapers, and flakes. The area given measured $274 \mathrm{~m}$ by $1371 \mathrm{~m}$. This raises the possibility that this site has yet to be relocated, or that it has been completely covered by sediments or removed by erosive factors. The site falls within the Wooded Island Archaeological District, but was not included on the original nomination forms. More intensive efforts to locate this site are required, including the use of shovel probes in order to locate buried cultural strata. If these efforts are unfruitful, then removal from the National Register is recommended.

45BN108. Located on the eastern bank of Wooded Island's mid-section, this house-pit village consists of at least five distinct depressions, three of which are also exposed in the terrace profile. Along the beach below the terrace are dense concentrations of artifacts lacking only temporally diagnostic artifacts and faunal remains. There are also eight obvious processing stations regularly 
spaced along the beach below the site. These consist of a hopper mortar, one or two large anvil stones, and a surrounding artifact scatter. The site currently measures $600 \mathrm{~m} \mathrm{~N} / \mathrm{S}$ by $50 \mathrm{~m} \mathrm{E} / \mathrm{W}$ and there is no obvious disturbance other than continuous terrace and river front erosion. The original description differs little from that provided here. This site was listed on the original Wooded Island Archaeological District Nomination form.

45BN110. Located on the southern tip of the northern portion of Wooded Island, the site consists of a single rock and charcoal hearth feature exposed in the cut bank. This feature is $70 \mathrm{~cm}$ below the ground surface and measures $50 \mathrm{~cm}$ wide by $30 \mathrm{~cm}$ deep. It is overlain by three distinct strata: a humus, a light tan sandy silt, and a light tan silty sand. The entire profile exposed is $\sim 110 \mathrm{~cm}$ high. While some artifacts (FCR and flaked cobbles) were noted on the ground surface on the terrace top, no other artifacts were noted in the exposed profile. It is assumed that additional evidence of human activity has eroded from this terrace and has been deposited along the terrace base. However, this area is obscured by dense vegetation. Called an open campsite, the original site description given by Rice (1969) states there were a series of hearth features exposed in the river terrace that extend to a depth of $14 \mathrm{ft}(4.3 \mathrm{~m})$. While $14 \mathrm{ft}(4.3 \mathrm{~m})$ of terrace is no longer visible, it is apparent that considerable erosion has taken place. Under the alluvium, which obscures the terrace profile, additional features may still be intact and would be protected from further erosion and vandalism. The site area given by Rice (1969) is $300 \mathrm{ft}(91 \mathrm{~m})$ by $200 \mathrm{ft}$ $(61 \mathrm{~m})$. This site falls within the Wooded Island Archaeological District and is listed on the original nomination form. The upper terrace surface is covered with post-1920 neoteric debris. While not evident in the site itself, four recently excavated waterfowl hunting blinds have been dug into otherwise undisturbed soil on the island. This practice, if allowed to continue, increases the likelihood that a prehistoric site will eventually be intentionally impacted, possibly leading to more excavation as artifacts are discovered.

45BN111,45BN112, and 45BN36. These three sites are being treated together because of their close proximity and morphological similarity. The sites are located on the western bank of the Columbia River just downstream from the northern end of Wooded Island. Sites 45BN111 and $45 \mathrm{BN} 112$ are described as fishing stations and are confined to the immediate shoreline. Both are listed on the original National Register nomination form for the Wooded Island Archaeological District. Site 45BN36 is located directly above the other two sites on top of the first terrace and is described as an open campsite. This site, though not listed on the original nomination form, falls within the district. No discernable boundary between these respective sites was evident in the field. Boundaries between Sites 45BN111 and 45BN112, as marked on the topographic maps, 
appear to coincide with areas of dense vegetation. The separation of Site 45BN36 must have been originally based on its physiographic position. Artifacts consisted of flaked and battered cobbles, net weights, and FCR, with cobble tools the most prevalent items. No faunal remains or diagnostic artifacts were noted. It appears that Site 45BN36 is the principal source for the artifacts scattered along the shoreline, although it is probable that the net weights and some cobble tools are located in situ. It is recommended that these sites be combined under a single designator because they are apparently part of a single complex. The total site area measures $315 \mathrm{~m} \mathrm{~N} / \mathrm{S}$ by $165 \mathrm{~m}$ E/W. Other than natural erosion these sites are undisturbed. Aside from modification of their status, no action is recommended.

\section{B.2.2 Savage Island Archaeological District}

45BN116. Situated on the west bank of the Columbia River directly across from the northern end of Savage Island, this site occupies a high terrace. Cultural material consists of a light surface scatter of artifacts, principally FCR and fined grained basalt (FGB) flakes. No artifacts appear on the terrace slope or along the shoreline below the site. Grasses and sage brush stabilize the site and, aside from a dirt track along the western boundary, there is no sign of disturbance. The remains of a homestead, removed when the Hanford Site was established, are located to the southwest of the site. The site measures $100 \mathrm{~m} \mathrm{NW/SE}$ by $80 \mathrm{~m} \mathrm{NE} / \mathrm{SW}$ and falls within the Savage Island Archaeological District. Because it is undisturbed and located on the mainland, this site has unique research potential.

45FR257. Located on the east bank of the Columbia River directly below Savage Island, this site is described by Rice (1968) as an open camp site with surface scatters of FCR, cobble tools, net weights, and hopper mortars. HCRL staff located the site and found that it is densely over grown with willows, making accurate assessment of area and content nearly impossible. It was determined that the site still existed and is currently well protected by the shrubbery. This site falls within the Savage Island Archaeological District.

45FR258. This extensive village and burial site, located on the southern tip of Savage Island, was evaluated last year as part of the annual monitoring program. Although no human remains have been located by earlier investigators or since the inception of the monitoring program, it is considered a burial site on the basis of informant testimony. Evidence of ongoing looter activity was discovered last year as well as extensive ground denudation resulting from cattle grazing. As per instructions specified in the HCRMP (Chatters 1989) "monitored sites receiving natural or anthropogenic impacts will be reinspected annually, at a minimum," this site was revisited to 
determine if these impacts are still occurring. Evidence of fresh looting was discovered. In several localized areas pits have been excavated into an exposed terrace profile uncovering a hearth feature, a lense of fresh water mussel shell, and numerous artifacts. Other evidence of recent human trespass includes abundant litter, footprints across the island, remains of recent camp fires, and even a picnic table erected on top of the terrace. Apparently, the cattle grazing has ceased or diminished. Vegetation has begun to reestablish itself and there is no evidence of cattle having recently been in the area. Evidence of previous looting appears to have been concentrated in a possible burial area, identifiable by the presence of flat schist-like stone, material not natural to the islands. An additional site description would be redundant at this point in the monitoring program. However, this revisit has pointed out that trespassing and vandalism continues to be severe. An aggressive law enforcement program may be the only solution to this persistent problem. The site is listed on the original Savage Island Archaeological District nomination form.

45FR259. Located along the western bank of Savage Island, this site was inaccurately described as a camp site with camp rock eroding out of the bank. Upon reevaluation it was noted that the entire site consisted of a surface scatter of primary deposition confined to the shoreline. Artifacts are exclusively net weights, and end flaked cobbles, which are more accurately described as cores, and their associated flakes. Additionally, for the entire length of the deposit, a distance greater than $800 \mathrm{~m}$, three parallel lines of regularly spaced boulders run parallel with the shoreline. No other island on the Hanford Site has a similar feature. Each boulder is of similar size and shape averaging about $70 \mathrm{~cm}$ in diameter. Each row apparently corresponds to common river levels and all seem to be related to some form of fishing apparatus. The entire site and the associated boulder feature need to be carefully recorded. Research into the probable function of this site and the other shoreline feature noted on Site 45GR317 will begin this fall.

\section{B.2.3 Hanford North Archaeological District}

45BN130. This site is a continuation of Site $45 \mathrm{BN} 129$, separated by a channel scar. Artifacts and FCR are eroding out of the terrace face. Rice (1968) only recorded the artifacts that had eroded from the terrace and were redeposited upon the river bank. It is possible that the terrace base vegetation was more dense 20 years ago and obscured the buried deposit. Both sites are listed on the original Hanford North Archaeological District nomination form. See discussion of Site 45BN129 under cemeteries.

45BN131. This site is located on the opposite end of the same unnamed island as Sites 45BN129 and 45BN130. Exposed in a terrace cut along the eastern edge of the island, artifactual material is 
concentrated along the terrace base. No cultural material was visible on the terrace; top. Artifacts include FCR, edge-modified cobbles and considerable quantities of CCS debitage (principally from final reduction and finishing stages). This type of lithic assemblage has been notably rare on previous sites visited. The site lacks vegetation cover and signs of localized looting, in the form of shallow shoreline excavations and recent piles of discarded artifacts, are evident. The site is listed on the original Hanford North Archaeological District nomination form. Increased surveillance is recommended.

\section{B.2.4 Snively Canyon Archaeological District}

45BN172 and 45BN173. Both of these sites are described by Rice (1968) as open camp sites exhibiting surface scatters of FCR, debitage, fragments of large mammal bone, and projectile points. They were listed on the inventory on the original Snively Canyon Archaeological District nomination form. Despite intensive field survey, neither site could be relocated because of the dense growth of cheat grass in the area. It is suggested that attempts to relocate these sites be undertaken in late winter when vegetation density is reduced.

\section{B.2.5 Locke Island Archaeological District}

45BN176. This site is listed on the National Register as an ethnographic Wanapum mat lodge camp situated on a gravel bar slightly downstream from the $100-\mathrm{H}$ reactor on the west bank of the Columbia River. The last period of occupation was reported to be 1942 . Field reconnaissance revealed that the site location has been covered by over $3 \mathrm{~m}$ of fill material during construction at 100-H. Given the recent period of use and that the site is probably still intact and protected beneath the fill, we do not recommend removal of the site from the National Register.

GR302b. Located on the west bank of Locke Island, $1.3 \mathrm{~km}$ above the island's southern tip, this house-pit village is described by Rice in his 1968 report simply as a dense concentration of camp rock (FCR) and several house pits. The site was given an area of $2500 \mathrm{ft}(762 \mathrm{~m})$ by $100 \mathrm{ft}$ $(30 \mathrm{~m})$. HCRL staff are now able to add additional detail to this description. Five house pits were observed and mapped. These depressions were considerably smaller than other house pits found on this and other channel islands, averaging only $2 \mathrm{~m}$ across. A hearth consisting only of a concentration of FCR was eroding out of the terrace face from an obvious house depression. Cobble tools, FCR, hopper mortar bases, and anvil stones are scattered along the shore below the site. No diagnostic artifacts or faunal remains were located. While terrace erosion is considerable, vegetation (e.g., willows) is becoming established along the terrace edge, which should help stabilize the 
face. Revised area measurements are $240 \mathrm{~m} \mathrm{NW} / \mathrm{SE}$ by $60 \mathrm{~m} \mathrm{NE} / \mathrm{SW}$. Numerous old looter pits are distributed across the site; however, there is no evidence of recent disturbance.

45GR305. This site is located on the northern end of Locke Island and is situated on the western edge of the first terrace overlooking a shallow channel that bisects the island. Rice briefly described the site as a few house-pit depressions and dense concentrations of FCR. Site area was given as $500 \mathrm{ft}(152 \mathrm{~m})$ by $200 \mathrm{ft}(61 \mathrm{~m})$. HCRL staff found a single, nearly buried house depression on the terrace top. The artifactual component of the site is restricted to the shoreline below the site. Hopper mortars, FCR, and cobble tools are profusely scattered along the bank. Debitage and faunal remains are absent and there is no sign of any disturbance. The site measures $240 \mathrm{~m} \mathrm{NW} / \mathrm{SE}$ by $20 \mathrm{~m} \mathrm{NE} / \mathrm{SW}$.

\section{B.2.6 Ryegrass Archaeological District}

45BN179 (as part of BN149). This site was evaluated last year and was found to have received negative impacts from fire break grading that had not undergone Section 106 review. This site was revisited this year to determine if impacts were repeated. No sign of continued grading was noted, nor were there any other signs of disturbance. The graded area is beginning to re-vegetate. This site is listed under the Ryegrass Archaeological District. An archaeological test pit opened by Rice $(1980 ; 1983)$ remains open and is contributing to site erosion. It is recommended that this pit be backfilled to stabilize the site.

\section{B.2.7 Gable Mountain/Gable Butte Archaeological District}

45BN354 \& 45BN355. The Western Washington University field school conducted surveys of sample plots during the summer of 1990. One of these plots was designated as sample plot 28B, which contains all of an isolated mesa and parts of a tableland. Both sites are located within this survey plot on the mesa. The sites are listed as rock cairns and were recorded by Rice in 1987. No site forms are available. Both are listed in the original Gable Butte/Gable Mountain Archaeological District inventory. Archaeological site HT-90-013 has been designated for the area of the mesa. Initial results indicated a total of 24 features consisting of various rock alignments and rock cairns. Later monitoring resulted in the addition of three more features. It is unclear which of these features are actually Sites $45 B N 354$ and 45BN355, but the numbers probably refer to two large oval shaped cairns noted during monitoring that are possible burials. As is typical for plateau type burials, large boulders are placed at either end of the cairns. The various rock alignments are mostly confined to the escarpment face. Some minor, recent disturbance has been noted as rocks being dislodged from the edge of the mesa. Further evaluation of this site is recommended. 


\section{B.3 SITES NOT LISTED ON THE NATIONAL REGISTER OF HISTORIC PLACES}

45BN38. Described as three distinct boulder piles averaging $\sim 1 \mathrm{~m}^{2}$, the site was supposed to be located on the west bank of the Columbia River above river mile 355 and directly across from the southern tip of an unnamed island. The area is currently an active dune field and no trace of these features could be found. During the original reconnaissance, no evidence of historic or prehistoric occupation or other activity could be found. Either this site is currently buried under the dunes or it is a natural feature and should be removed from the state records.

45BN42. This site is located near the center of Johnson/Capp Island situated near the highest point of the island along the east bank. Wind scalloping has created an undulating surface that has been heavily grazed by geese, creating $80 \%$ ground exposure. Soils are fine aeolian sand overlooking a cobble shore. The site area measures $190 \mathrm{~m} \mathrm{~N} / \mathrm{S}$ by $25 \mathrm{~m} \mathrm{E} / \mathrm{W}$. Artifacts are restricted to the beach strand and the terrace cut face. Listed in order of abundance the artifacts encountered are: FCR, edge-ground, battered, and flaked cobbles, mortars and pestles, basalt cores, and a few FGB primary and secondary flakes. No diagnostic artifacts were observed. Faunal remains are conspicuous in their absence. The site is subject to erosion during high water, which causes terrace slumping. There is no evidence of anthropogenic disturbance. It may be beneficial to promote vegetation growth to restrain terrace erosion. The site is mislocated on the map provided by Rice (1969).

45BN115. This site is located at the mouth of an old river channel, midpoint on the east bank of an unnamed island across from Ringold, Washington. It consists of two distinct concentrations of FCR and artifacts, mostly edge-modified cobbles. The northern most concentration measures $5 \mathrm{~m}^{2}$ and the southern $3 \mathrm{~m}$ by $2 \mathrm{~m}$. Aside from some reworking during periods of high water, the site appears undisturbed and largely intact. The area measures $60 \mathrm{~m} \mathrm{E} / \mathrm{W}$ by $35 \mathrm{~m} \mathrm{~N} / \mathrm{S}$. Listed as an open camp by Rice (1969), the basic description is very similar to that provided here. The concentrations noted above were called hearth features by Rice. A pestle with a carved design was noted by Rice but could not be relocated, which suggests that surface collecting has been carried out on the site.

45BN164. The site is located on the southernmost tip of Johnson Island. Although cultural material is found along the strand, the majority is concentrated along the top of the first terrace covering an area $65 \mathrm{~m} \mathrm{~N} / \mathrm{S}$ by $65 \mathrm{~m} \mathrm{E} / \mathrm{W}$. There is a slight humus development on this terrace overlying fine silty sand mixed with unsorted river cobbles. Grasses and willows stabilize the 
ground surface. Artifacts consist of FCR, ground and battered cobbles, mortars and pestles. No debitage or organic remains were noted. There is active erosion along the terrace edge during periods of high water and from boat wakes, but no evidence of direct anthropogenic disturbance. No recommendations.

45BN168. This site is located across from Wooded Island on the west bank of the Columbia River, and is bounded on the south by the second terrace, on the west by a dirt track, and on the north by a swale. It covers an area measuring $50 \mathrm{~m} \mathrm{~N} / \mathrm{S}$ by $25 \mathrm{~m} \mathrm{E} / \mathrm{W}$. Vegetation is principally grasses interspersed with sage. The soils are fine silty sands. Three depressions were located, two measuring $3 \mathrm{~m}$ in diameter and the other $\sim 5 \mathrm{~m}$. Artifact density is extremely low, considering the presence of house pits. Although the original ground surface is covered with eolian material, artifact concentrations are usually dense along the adjacent beach. Artifacts consist of some FCR and cobble tools. Faunal remains consist of a single localized shell lense. No diagnostic artifacts were recovered. Active erosion is restricted to the terrace margin and there is no evidence of anthropogenic disturbance. This site should be evaluated for potential nomination to the National Register.

45FR264. This is an extensive scatter of artifacts visible only within a dune blowout. The site is located on the east bank of the Columbia River $2.4 \mathrm{~km}$ downstream from the White Bluffs boat ramp. A large spring originates in the bluffs to the northeast of the site and drains into the river directly below the site. The site conservatively measures $240 \mathrm{~m} \mathrm{NE} / \mathrm{SW}$ by $320 \mathrm{~m} \mathrm{NW} / \mathrm{SE}$, an area that corresponds to the deflated portion of the dune. Numerous discrete activity areas were evident, each containing one hopper mortar and minimally one but usually two anvil stones amidst a scatter of FCR, cobble tools, and CCS flakes. Rice's (1968) basic description of the site appears accurate, but failed to note the activity areas. He did, however, find numerous "archaic" projectile points across the site surface. After a systematic survey of the entire site surface by HCRL personnel, not a single projectile point was discovered, which suggests that the site has been repeatedly collected in the past. This site is interesting because of its size, content, location, and by the suggestion of its considerable antiquity. Further evaluation is recommended.

45FR266. Located directly above the White Bluffs boat ramp on the East Bank of the Columbia River is a small one-room log cabin. Reported to have been built around 1890 by a family of settlers, little is actually known about its history. Test excavations were conducted by Rice (1976) but no conclusions were reached. As one of the few standing historical structures in the region, 
this is a very significant cultural resource. The site has been fenced to deter trespassing; however the fence is only four strands of barbed wire and is easily breached. Evidence of trespassing abounds, such as litter inside the cabin and some graffiti. The greatest current threat to the cabin is the open test pits from Rice's investigations. As these naturally erode and fill in, the foundation is slowly being undermined and the cabin is beginning to shift. We recommend that these be filled and that action be undertaken to stabilize this structure and prevent its eventual collapse. Clearly eligible, this site needs to be nominated for the National Register.

45GR301. This site is located on the east bank of the Columbia River, $0.8 \mathrm{~km}$ above the White Bluffs boat ramp. Descriptions provided by Rice (1968) proved to be largely correct. The site is situated near a narrow bay and wetland formed by an abandoned meander scar. The site is eroding out of a 3-to 4-m-high terrace bounded on the south by the wetland. Artifacts are covered by approximately $1.5 \mathrm{~m}$ of overburden and are not continuous along the entire terrace face. The site extends for a distance of approximately $300 \mathrm{~m}$. Material observed includes shell lenses of Margaritifera, concentrations of FCR, cobble tools, and a single hopper mortar base. Only material still embedded in the terrace was visible. Soil slump obscures the terrace base, as does dense vegetation. Artifacts washed downslope from the terrace are quickly inundated by the wetland. No diagnostic artifacts were located. There is no sign of human disturbance and vegetation appears to be stabilizing much of the terrace bank. Inspection of the terrace top revealed no disturbance, indicating the remainder of the buried site is largely intact and undisturbed.

\section{B. 4 REFERENCES}

Chatters, J. C., ed. 1989. Hanford Cultural Resources Management Plan. PNL-6942, Pacific Northwest Laboratory, Richland, Washington.

Drucker, P. 1948. An Appraisal of the Archaeological Resources of McNary Reservoir. OregonWashington Columbia Basin Project. River Basin Surveys. Smithsonian Institution, Washington, D.C.

Rice, D. G. 1968. Archaeological Reconnaissance: Ben Franklin Reservoir Area. Washington State University, Laboratory of Anthropology, Pullman, Washington.

Rice, D. G. 1969. Preliminary Report. Marmes Rockshelter, Archaeological Site, Southern Columbia Plateau. Report submitted to the National Park Service, Seattle, Washington.

Rice, D. G. 1976. A Log Structure at White Bluffs Landing Franklin County, Washington: A Case Study in Historical Archaeology. University of Idaho Anthropological Research Manuscript Series, No. 25, University of Idaho, Moscow, Idaho. 
Rice, D. G. 1980. Overview of Cultural Resources on the Hanford Reservation in South Central Washington State. RL-E-80-0043, prepared for the U.S. Department of Energy, Richland Operations, Richland, Washington.

Rice, D. G. 1983. Archaeological Investigations at Washington Public Power Supply System Nuclear Plants on the Hanford Reservation. Washington. Washington Public Power Supply System, Richland, Washington. 
APPENDIX C

RANDOMLY SELECTED SURVEY PLOTS

INVESTIGATED IN FY 1990 


\title{
APPENDIX C \\ RANDOMLY SELECTED SURVEY PLOTS \\ INVESTIGATED IN FY 1990
}

\begin{abstract}
During the 1990 Fiscal year, 13 randomly selected plots of 40 acre-size $\left(0.16 \mathrm{~km}^{2}\right)$ were surveyed for cultural resources as part of the Section 110 inventory of the Hanford Site. Table C.1 summarizes those plots and the cultural resources found in them. HT numbers designate archaeological sites given temporary Hanford Site numbers; HI designates isolated artifacts.
\end{abstract}

C. 1 
TABLE C.1. Summary of Random Plots Surveyed in Fiscal Year 1990

\begin{tabular}{|c|c|c|c|c|}
\hline Plot\# & Legal Description & Surveyed & Isolaes & Sites \\
\hline 1033SD & SW $1 / 4$, SW $1 / 4$ Sec.26 T12N-R28E & $4 / 5 / 90$ & & \\
\hline 346AD & SE1/4, SW1/4 Sec.227 T12N-R228E & $4 / 5 / 90$ & & \\
\hline $7771 \mathrm{~F}$ & SW1/4, SW/1/4 Sec.7 T13N-R25E & $6 / 27 / 90$ & $\begin{array}{l}\text { HI-90-002: } 2 \text { flakes } \\
\text { HI-90-003: enamel pan } \\
\text { HI-90-004: ccs flake }\end{array}$ & $\begin{array}{l}\text { HT-90-006: lithic scatter } \\
\text { HT-90-007: caim } \\
\text { HT-90-008: lithic scatter } \\
\text { HT-90-009: can scatter } \\
\text { HT-90-010: can scatter } \\
\text { HT-90-01 1: can scatter } \\
\text { HT-90-012: can scatter }\end{array}$ \\
\hline $28 \mathrm{~B}$ & NW 1/4, NE1/4 Sec.19 T13N-R26E & $6 / 28 / 90$ & & $\begin{array}{l}\text { HT-90-013: rock features } \\
\text { HT-90-014: lithic scatter }\end{array}$ \\
\hline 679SC & SE1/4, NE1/4 Sec.35 T11N-R26E & $7 / 3 / 90$ & & HT-90-015: lithic scatter \\
\hline 643SL & SE1/4, NE1/4 Sec.35 T11N-R26E & $7 / 3 / 90$ & HI-90-005: ccs flake & \\
\hline 2188SD & NW1/4, SW1/4 Sec.34 T11N-R27E & $7 / 4 / 90$ & & HT-90-016: caim Hist./prehist \\
\hline 155ES & SE1/4, SE1/4 Sec.32 T11N-R27E & $7 / 5 / 90$ & & \\
\hline $156 \mathrm{ES}$ & NE $1 / 4$, NE1/4 Sec.32 T11N-R27E & $7 / 5 / 90$ & $\begin{array}{l}\text { HI-90-006: d.soldered can } \\
\text { HI-90-012: ccs flake }\end{array}$ & HT-90-017: can scatter \\
\hline $428 \mathrm{CCFG}$ & SE $1 / 4$, SW $1 / 4$ Sec.T11N-R27E & $7 / 5 / 90$ & & \\
\hline $718 \mathrm{SD}$ & NE $1 / 4, S E 1 / 4$ Sec.16 T12N-R27E & $7 / 6 / 90$ & & \\
\hline $400 S L$ & NW 1/4, SW1/4 Sec.12 T11N-R25E & $7 / 9 / 90$ & $\begin{array}{l}\text { HI-90-007: flakes } \\
\text { HI-90-008: flake } \\
\text { HI-90-009: flake } \\
\text { HI-90-010: flakes }\end{array}$ & $\begin{array}{l}\text { HT-90-018: lithic scatter } \\
\text { HT-90-019: lithic scatter } \\
\text { HT-90-020: lithic scatter/cans } \\
\text { HT-90-021: lithic scatter }\end{array}$ \\
\hline
\end{tabular}

220SL SW $1 / 4$, SE $1 / 4$ Scc.28 T12N-R25E 7/10/90 


\section{DISTRIBUTION}

No. of

Copies

\section{OFFSITE}

2 DOE/Office of Scientific and Technical Information

Jacob Thomas

State Historic Preservation Officer

Office of Archaeology \& Historic Preservation

111 West 21st Ave., KL-11

Olympia, WA 98504-5411

Thomas King

Advisory Council on Historic Preservation

The Old Post Office Building

1100 Pennsylvania Ave., NW \#809

Washington, D.C. 20004

Duane Hogan

U.S. Army Corps of Engineers

Box C-3755

Seattle, WA 98124-2255

Dennis Canty

National Park Service, Pacific

Northwest Region

83 King St., Suite 212

Seattle, WA 98104

John Leier

U.S. Army Corps of Engineers

Walla Walla District

Building 602, City-County Ariport

Walla Walla, WA 99362-9265

Bruce Crespin

U.S. Bureau of Land Management

Burns, OR 97720
No. of

Copies

2 Colville Confederated Tribes

Attn: Tribal Council Adeline Fredin

P.O. Box 150

Nespelem, WA 99155

2 Nez Perce Tribe

Attn: Tribal Council

P.O. Box 305

Alan Slickpoo

Lapwai, ID 83540

2 The Confederated Tribes of the Umatilla Indian Reservation

Attn: Tribal Council Jeff Van Pelt

P.O. Box 638

Pendleton, OR 97810

2 The Wanapum Indian Tribe

Attn: Tribal Council Rex Buck, Jr.

P.O. Box 275

Beverly, WA 99321

2 The Yakima Indian Nation

Attn: Tribal Council Bill Yallup

P.O. Box 151

Toppenish, WA 98948

\section{ONSITE}

26 DQE Field Office, Richland

K. V. Clarke

P. F. Dunigan

N. M. Highland

M. B. Hitt 
No. of No. of

Copies

Copies
R. D. Izatt
K. H. Jackson
C. R. Pasternak (15)
E. E. Pride
J. R. Shadel
P. H. Turner
K. J. Wheeless
DOE Legal Library

5 Westinghouse Hanford Company

G. D. Carpenter

M. T. Jansky

K. W. LeLiefeld

D. L. Mills

J. F. Woods

39 Pacific Northwest Laboratory

T. L. Brown

J. C. Chatters (20)

C. E. Cushing

J. W. Falco

H. A. Gard (2)

R. H. Gray

J. M. Hales

P. C. Hays

R. E. Jaquish

P. E. Minthorn

W. H. Rickard

L. E. Rogers

R. L. Skaggs

Publishing Coordination

Technical Report Files (5) 

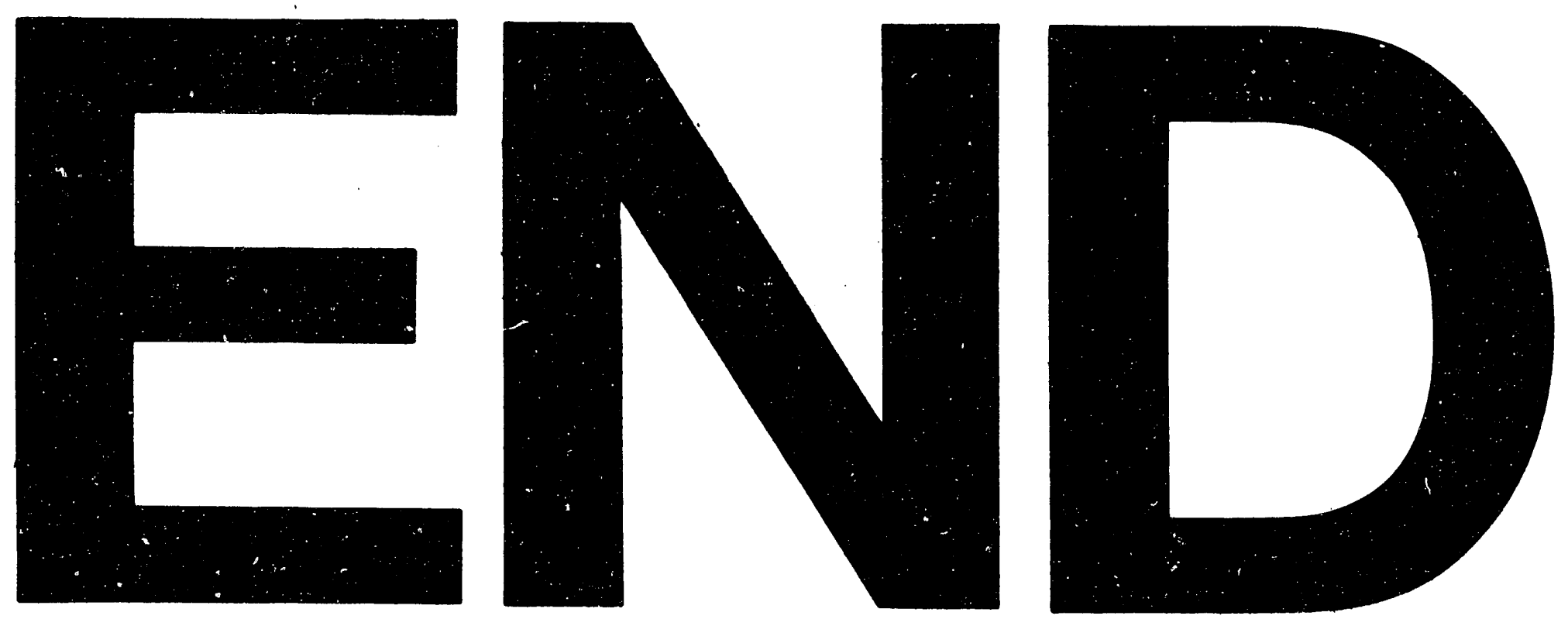

7
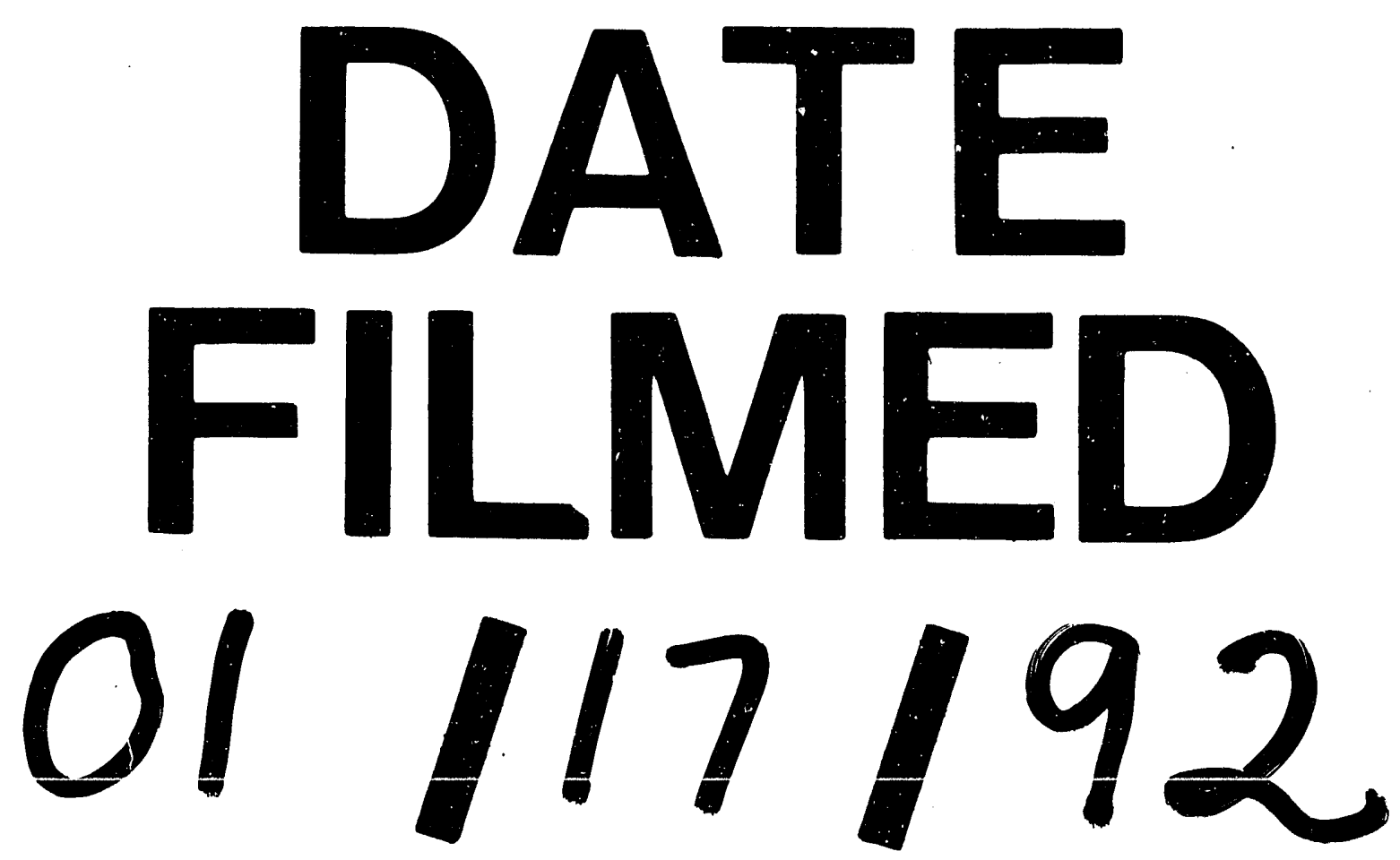
